\title{
Cretaceous faunas from Zululand and Natal, South Africa. The Albian ammonite genus Douvilleiceras de Grossouvre, 1894
}

\author{
William James Kennedy \\ Oxford University Museum of Natural History, Parks Road, Oxford OX1 3PW \\ Department of Earth Sciences, South Parks Road, Oxford OX1 3AN, U.K. \\ E-mail: jim.kennedy@oum.ox.ac.uk \\ \& \\ Herbert Christian Klinger \\ Natural History Collections Department, Iziko South African Museum, P.O. Box 61, Cape Town, 8000, \\ South Africa, and 6 du Toit Street, Porterville, 6810 South Africa \\ E-mail: hkling@telkomsa.net \\ (with 23 figures) \\ Received 23 June 2014. Accepted 3 September 2014
}

\begin{abstract}
The cosmopolitan ammonite genus Douvilleiceras de Grossouvre, 1894, is the commonest ammonite in the Lower and lower Middle Albian in northern KwaZulu-Natal. Two variable, dimorphic species, D, mammillatum (Schlotheim, 1813) and D. inaequinodum (Quenstedt, 1849) are recognized, of which the majority of previously named taxa referred to the genus are regarded as synonyms.
\end{abstract}

Keywords: Cretaceous, ammonite, Albian, Douvilleiceratinae, KwaZulu-Natal, South Africa.

\section{CONTENTS}

\begin{tabular}{|c|}
\hline Abstract \\
\hline Introduction $\ldots \ldots \ldots$ \\
\hline Conventions \\
\hline Repositories of specimens \\
\hline Locality details \\
\hline
\end{tabular}

\section{INTRODUCTION}

Douvilleiceras de Grossouvre, 1894, is a cosmopolitan genus that ranges through most of the Lower Albian and into the basal Middle Albian; the type species, Douvilleiceras mammillatum (Schlotheim, 1813) is a global marker fossil for this interval. More than forty species and varieties have been assigned to the genus, and previous authors have adopted very different approaches, some recognizing many, often co-occurring species and varieties (Casey 1962; Owen 1988), a few, variable dimorphic species (Cooper 1982) or, in the case of northwest European occurrences, only two successive species (Amédro 1992, p. 198). The reasons for these different approaches are several (Cooper 1982, p. 271): narrow species concepts that recognize only limited intraspecific variation; failure to recognize large and small individuals as dimorphs, and failure to recognize that immature specimens of the same size may be macro- and microconchs at different ontogenetic stages. A further complication noted by Casey (1962, p. 264) is a taphonomic one: many of the classic occurrences of Douvilleiceras in Europe (and indeed elsewhere: Kennedy \& Fatmi 2014) are in condensed phosphatic nodule beds where only nuclei and small individuals (commonly internal moulds) are differentially preserved. The interest of the present material is that it comes from expanded terrigenous-clastic sequences with juveniles and adult macroconchs and microconchs.

Wherever large numbers of Douvilleiceras are known, they commonly fall into two groups (Amédro 1992). In the mammillatum group, the ornament of the late phragmocone and early adult body chamber are characterized by septate umbilical and inner ventrolateral spines (conical tubercles on internal moulds), a weak inner lateral bulla, and a ventrolateral shoulder bearing up to six rows of clavi, developed from a system of spiral grooves and ridges borne on a blunt outer ventrolateral bulla in the earlier ornamented ontogenetic stages. There is a shallow ventral sulcus in costal section, although this may narrow on adult body chambers, and a feeble siphonal clavus may develop. In northwest European successions they vary from relatively broad in the earliest member of the group (Douvilleiceras leightonense Casey, I962, p. 274, pl. 41, fig. 1; pl. 42, fig. 3; text-figs 96, 97, 102i, 103e-h; see Figs 1, 2, herein), and narrower in the later, upper Lower Albian D. mammillatum (Schlotheim, 1813) (Fig. 3), and may be lost in some individuals 
(Fig. 4). The second, Douvilleiceras inaequinodum group, is characterized by hypernodosity, with the development of large, finger-like outer ventrolateral tubercles bearing spiral grooves and ridges (Fig. 5), the latter corresponding to the ventrolateral clavi of the mammillatum group at the same ontogenetic stage. In both groups, tuberculation declines and effaces progressively, with ribs dominant on the later parts of the adult body chamber (Figs 2, 7). It is perfectly possible that, at any stratigraphic level, these two groups are merely parts of a continuum of variation in a single species, given the wide range of intraspecific variation shown by many other ammonite species (as with the classic example of Neogastroplites: Reeside \& Cobban 1960); the present material does not, however, allow us to demonstrate this.

\section{CONVENTIONS}

Dimensions are given in millimetres: $\mathrm{D}=$ diameter; $\mathrm{Wb}=$ whorl breadth; $\mathrm{Wh}=$ whorl height; $\mathrm{U}=$ umbilicus; $\mathrm{c}=$ costal dimension; ic $=$ intercostal dimension. Figures in brackets are dimensions as a percentage of the diameter. The suture terminology is that of Korn et al. (2003): $\mathrm{E}=$ external lobe; $\mathrm{A}=$ adventive lobe (= lateral lobe, $\mathrm{L}$, of Kullmann \& Wiedmann 1970); U = umbilical lobe; I = internal lobe.

\section{REPOSITORIES OF SPECIMENS}

BGS: British Geological Survey, Keyworth, Nottinghamshire.

BMNH: The Natural History Museum, London.

SAM: The South African Museum, Cape Town. (Due to building alterations, collections in the Natural History Collections Department of the museum, are currently not available for study.)

OUM: Oxford University Museum of Natural History.

\section{LOCALITY DETAILS}

Details of field localities are given by Kennedy \& Klinger (1975); further descriptions of these localities are deposited in the Geological Collections, Oxford University Museum of Natural History, The Natural History Museum, London, and the Natural History Collections Department, Iziko, South African Museum, Cape Town. The present material comes from the following localities in association with the ammonite taxa noted below.

Locality 35. Cliff and stream sections extending over several hundred metres along the Mzinene, approximately $1200 \mathrm{~m}$ $\mathrm{NE}$ of the farm Amatis, north of Hluhluwe, 27 $58^{\prime} 03^{\prime \prime} \mathrm{S}$, $32^{\circ} 18^{\prime} 31^{\prime \prime}$ E. Mzinene Formation, Albian III. Aioloceras besairiei (Collignon, 1949), Carinophylloceras collignoni Klinger, Wiedmann \& Kennedy, 1975, Ammonoceratites (Ammonoceratites) mahadeva (Stoliczka, 1865), Anagaudryceras sacya (Forbes, 1846), Umsinenoceras linguatuberculatum Kennedy, Wright \& Klinger, 1979, Beudanticeras komihevitraense Collignon, 1950, Alopecoceras ankeritterae Kennedy \& Klinger, 1978, Lyelliceras latilii Kennedy \& Klinger, 2008, Protanisoceras (Rossalites) aff. superbus (Collignon, 1949). The assemblage is dated as upper Lower Albian on the basis of common taxa occurring at locality 53 , noted below.
Locality 36. Degraded river cliff on the eastern bank of the Mzinene, close to the boundary of lots H84 14107 and H 85 14108 , north of Hluhluwe, $27^{\circ} 57^{\prime} 14^{\prime \prime} \mathrm{S}, 32^{\circ} 18^{\prime} 34^{\prime \prime} \mathrm{E}$. Mzinene Formation, Albian III. C. collignoni, A. sacya, A. besairiei, B. komihevitraense, D. mammillatum. Upper Lower Albian.

Locality 53. Derelict dam site on Indabana 13162, $2.2 \mathrm{~km}$ south of the farm Izwehelia, north of Hluhluwe, $27^{\circ} 52^{\prime} 24^{\prime \prime} \mathrm{S}$, $32^{\circ} 19^{\prime} 02^{\prime \prime}$ E. Mzinene Formation, Albian III. Desmoceras latidorsatum (Michelin, 1838), A. besairiei, A. ankeritterae, Tegoceras mosense (d,Orbigny, 1841), D. mammillatum, $D$. orbignyi. The presence of $T$. mosense dates the assemblage to the late Early Albian; in Western Europe the species ranges from the Cleoniceras floridum Subzone of the Sonneratia chalensis Zone to the Protohoplites puzosianus Subzone of the Otohoplites auritiformis Zone, the midDouvilleiceras mammillatum Zone of authors.

Locality 142. Hillside east of track leading to mine in the southern part of the Mkuze Game Reserve, $27^{\circ} 44^{\prime} 24^{\prime \prime} \mathrm{S}$, $32^{\circ} 17^{\prime} 12^{\prime \prime}$ E. Mzinene Formation, Albian III. C. collignoni, A. besairiei, D. mammillatum, D. inaequinodum. Upper Lower Albian, as locality 53.

Locality 154. Abandoned road metal quarry south of track $500 \mathrm{~m}$ east of Mantuma Camp, Mkuze Game Reserve, $27^{\circ} 35^{\prime} 33^{\prime \prime} \mathrm{S}$, $32^{\circ} 13^{\prime} 38^{\prime \prime} \mathrm{E}$. Mzinene Formation, Albian III. Oxytropidoceras (O.) alticarinatum Spath, 1922, Lyelliceras lyelli (d'Orbigny, 1841), L. pseudolyelli (Parona \& Bonarelli, 1897), Pseudobrancoceras versicostatum (Michelin, 1838), Ndumuiceras variabile Kennedy \& Klinger, 2009, Mkuziella andersoni Klinger \& Kennedy, 2008, D. mammillatum, D. inaequinodum. Lower Middle Albian.

Locality 169. Mfongosi Spruit, gully and adjacent hill slopes on the north side of the stream $2 \mathrm{~km}$ east of the old drift, $27^{\circ} 31^{\prime} 38^{\prime \prime} \mathrm{S}, 32^{\circ} 09^{\prime} 57^{\prime \prime} \mathrm{E}$. Mzinene Formation, Albian II-III. D. mammillatum, D. cf. inaequinodum. Upper Lower Albian.

Locality 174. Mlambongwenya Spruit, shallow excavations and road sections extending from the store south towards the drift, $27^{\circ} 11^{\prime} 02^{\prime \prime} \mathrm{S}, 32^{\circ} 11^{\prime} 25^{\prime \prime} \mathrm{E}$. Mzinene Formation, Albian III. C. collignoni, Bhimaites sp., D. mammillatum, D. inaequinodum. Upper Lower Albian.

Locality 175. Exposures in and around gully west of the track leading SW from Ndumu in Impala, $300 \mathrm{~m}$ south of

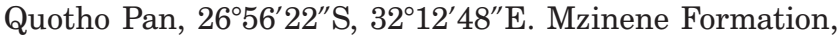
Albian II-III. Eotetragonites (Eotetragonites) raspaili raspaili Breistroffer, 1947, Tegoceras camatteanum (d'Orbigny, 1841), T. mosense, N. variabile, D. mammillatum. Upper Lower Albian, as locality 53.

Locality 176. Slopes south of the track and north of Quotho Pan across the boundary of Impala and Wisteria 18122 sections, $26^{\circ} 55^{\prime} 59^{\prime \prime} \mathrm{S}, 32^{\circ} 12^{\prime} 48^{\prime \prime} \mathrm{E}$. Mzinene Formation, Albian III. Lyelliceras lyelli, L. pseudolyelli, Pseudobrancoceras versicostatum, $M$. andersoni, D. mammillatum. Lower Middle Albian.

Southwest of Ndumu; scattered outcrops of the Mzinene Formation. The presence of Lyelliceras pseudolyelli and L. lyelli indicate the presence of upper Lower and Lower Middle Albian. 


\section{SYSTEMATIC PALAEONTOLOGY}

\section{Suborder ANCYLOCERATINA Wiedmann, 1966 \\ Superfamily DOUVILLEICERATOIDEA Parona \& Bonarelli, 1897 \\ Family DOUVILLEICERATIDAE Parona \& Bonarelli, 1897 \\ Subfamily DOUVILLEICERATINAE Parona \& Bonarelli, 1897}

\section{Genus Douvilleiceras de Grossouvre, 1894 \\ $(?=$ Trinitoceras Scott, 1940, p. 1016; ? = Eodouvilleiceras Casey, 1961, footnote on p. 191))}

\section{Type species}

Ammonites mammillatus Schlotheim, 1813, p. 111, by the original designation of de Grossouvre, 1894, p. 26; ICZN Opinion 422, 1956; ICZN Specific Name no. 764.

\section{Diagnosis}

There are four successive ontogenetic stages following the initial smooth stage. In the first ornamented ontogenetic stage, primary ribs bear inner ventrolateral spines (conical tubercles on internal moulds) and outer ventrolateral bullae, linked over the venter by a low transverse rib, succeeded by a ventrolateral and ventral constriction, with occasional nontuberculate intercalated ribs. In the second ornamented stage, umbilical spines (tubercles on internal moulds) appear on the primary ribs, and the ventrolateral bullae, strong to weak, develop a spiral groove separating spiral ridges. In the third ornamented stage, a weak inner lateral tubercle appears, and the outer ventrolateral bulla develops additional spiral grooves, separated by spiral ridges. The outer ventrolateral bulla may efface, leaving the ventrolateral shoulder ornamented by up to six rows of ventrolateral clavi, developed from the spiral ridges, or strengthen into a massive, blunt horn; intercalated ribs may be present with or without tubercles. A mid-ventral sulcus is present in costal section.This stage extends onto the adapical part of the adult body chamber. In the fourth ornamented stage, the tubercles decline and efface, the umbilical bullae persisting or not, the ribs primaries plus long and short intercalated ribs. A delicate siphonal clavus may appear, and the mid-ventral sulcus is lost. Markedly dimorphic, with adult macroconchs reaching diameters of up to $800 \mathrm{~mm}$. A dorsal callosity covers the ventrolateral shoulders and venter and partially encloses the inner ventrolateral spines. Suture quadrilobate, E/A large, bifid, A trifid.

\section{Discussion}

The sequence of early ontogenetic stages seen in Douvilleiceras was already recognized by Jacob (1905, p. 414), as noted by Latil (2011, p. 369). In most areas where there are significant numbers of Douvilleiceras, they fall, as indicated in the diagnosis, into two morphological groups, here termed the mammillatum and inaequinodum groups. The former is characterized by the decline of the outer ventrolateral bulla and its replacement by several rows of ventrolateral clavi on the ventrolateral shoulder in the third ornamented stage, as a result the mid-ventral sulcus is shallow, varying from broad in D. leightonense Casey, 1962 (Figs 1, 2) to as wide or only slightly wider than the gap between the ventrolateral clavi, as in some variants of $D$. mammillatum: the Douvilleiceras clementinum (d'Orbigny, 1841) of authors (Fig. 4), where a siphonal clavus may develop. The orbignyi group, in contrast, are characterized by the strengthening of the outer ventrolateral tubercle into a blunt horn (Fig. 5), seen at its most extreme development in $D$. benonae Besairie, 1936 (p. 164, pl. 15, figs 15, 16; see also Collignon, 1963, pl. 284, fig. 1244). In both groups, this ornament extends onto the adapical part of the adult body chamber, after which tubercles decline and efface, and may be lost altogether.

The genus Trinitoceras Scott, 1940 (type species Trinitoceras rex Scott, 1940, p. 1017, pl. 60, figs 1-3) was regarded as a synonym of Douvilleiceras by Wright (1957, p. L387) and others. Scott's original account is as follows: 'a very large ammonite from the southern Quitman Mountains is clearly a douvilleiceratid, but it differs by so many characters from the species of the group of $D$. mammillatum, to which the name Douvilleiceras is now restricted, that a new genus is here created for it.... The douvilleiceratid sculpture is evident up to or beyond a diameter of $200 \mathrm{~mm}$. Costae are multi-tuberculate as in Douvilleiceras, but the umbilical tubercles are greatly exaggerated in size, forming large bullae on the umbilical margin at the ends of alternate costae. On later whorls costae lose all trace of tuberculation, but retain, irregularly, their alternate primary and secondary arrangement. On the latest whorls shown, the ribs are nearly all equal, except that an occasional secondary (marked only by the fact that it does not reach the umbilicus) is intercalated between the primaries. The whorl section, degree of evolution, and umbilical area do not differ greatly from like features of well-known species of Douvilleiceras.' Casey (1962, p. 264) also regarded Trinitoceras as a subjective synonym of Douvilleiceras 'confirmed by an inspection of casts of Scott's types supplied me by the U.S. National Museum.' However, The type material of the type species, T. rex, is in the collections of the Bureau of Economic Geology Austin, Texas, and it is the syntypes of the second species referred to Trinitoceras, T. reesidei, that are in the U.S. National Museum of Natural History. Cooper (1982, p. 270) also concluded that Trinitoceras Scott, 1940, was based on large individuals 'that accompany virtually all Douvilleiceras populations' and interpreted them as macroconchs.

Young (1974, p. 187, pl. 6, fig. 10; pl. 7, figs 1, 5; text-figs 3d, $3 a$, i) refigured the holotype of T. rex, as did Robert (2002, pl. 38, figs 1-3). The figures of the earliest growth stages known, at a diameter of about $200 \mathrm{~mm}$ according to Young (1974, pl. 6, fig. 10; pl. 7, fig. 5; text-fig. 3i), show an approximately $90^{\circ}$ fragment with a maximum preserved whorl height of 75-80 mm. Parts of 10 coarse straight rectiradiate ribs are preserved on the fragment. Primary ribs bear coarse umbilicolateral bullae, inner ventrolateral bullae and outer ventrolateral tubercles, linked across the venter by a broad rib. They are separated by a single intercalated rib with inner and outer ventrolateral tubercles. On the outer whorl, which extends to a diameter of over $400 \mathrm{~mm}$, all trace of tubercles is lost, the primary ribs separated by single intercalated ribs. The specimen is clearly a macroconch. It comes from the upper half of the blue marls of the Cuchillo Formation at the mouth of Mayfield Canyon, on the north bank of the Rio Grande in Trans-Pecos Texas, downstream from Indian Hot Springs at Scott's locality M1 (1940, fig. 139 
on p. 984). This locality has yielded Upper Aptian Rhytidohoplites and Hypacanthoplites as well as Lower Albian Douvilleiceras. The ornament of the poor fragment of the inner whorl of the holotype of T. rex does not correspond to that of Douvilleiceras, and we are less certain than previous authors as to its being a junior synonym of Douvilleiceras; it may even be a cheloniceratine. Adult whorls of macroconch Douvilleiceras certainly resemble the adult whorls of $T$. rex, as with specimens here referred to D. mammillatum, as with the specimen figured by Casey (1962, text-fig. 91 on p. 262) as Douvilleiceras clementinum (d'Orbigny, 1841), and the huge (440 mm diameter) macroconch of Douvilleiceras leightonense Casey, 1962 (text-fig. 96 on p. 275). The holotype of leightonense (Casey 1962 , pl. pl. 41, fig. 1) is a microconch of the same species, and has comparable adult body chamber ornament. We would note, however, that adult macroconch cheloniceratines show similar ornament (Casey 1962).

Latil (2011, p. 369) regarded Eodouvilleiceras Casey, 1961, p. 191, footnote 1) as a synonym of Douvilleiceras. It was introduced as follows: 'Eodouvilleiceras gen. nov. (type species Douvilleiceras horridum Riedel, 1937 [1938], p. 29, pl. 6, figs 1, 2, Upper Aptian, Colombia. Douvilleiceratinae with simple ribbing and mammiliform ventral tubercles of Douvilleiceras, but with tubercles undivided to an advanced stage of growth.... Characteristic of the uppermost Aptian of South America, but represented perhaps in the 'Clansayes' fauna of France by 'D.' clansayense Jacob (1905, p. 413, pl. xiii, figs $4 \mathrm{a}-\mathrm{c}$; non ' $D$.' clansayense Jacob [\& Tobler], 1906 = Cheloniceras helveticum Breistroffer.' Casey subsequently (1962, fig. 90 on p. 261) illustrated a specimen identified as Eodouvilleiceras horridum from the 'Upper Aptian' near Bogota, Colombia. Etayo-Serna (1979, p. 57) stated that 'The specimen illustrated by Casey (1962, p. 261, text-fig. 90) as ' $E$. horridum (Riedel), Upper Aptian near Bogotá' is more like E. pedrocarvajali [Etayo-Serna, 1979, p. 57, pl. 8, fig. 1; text-figs 6Q, U] than like Riedel's species. Both Riedel's species and Casey's figured specimen lack any stratigraphic information (See Riedel, 1938, p. 31; also Univ. California Mus. Paleont. Files).' Latil (2011, p. 369) noted that the holotype of Douvilleiceras horridum differed mainly from Epicheloniceras species by 'the presence of few intercalatories, high ribs on ventral area and ventrolateral tubercles that are clearly divided into two tubercles, a strong internal one and a weak external one. These diagnostic features do not appear on the late Aptian 'Douvilleiceras clansayense JACOB, 1905 (p. 413, pl. 13, fig. 4)... Jacob, 1905 (p. 414, pl. 13, fig. 5) pointed out that the ontogeny of some juvenile, primitive members of the genus Douvilleiceras from the condensed lower Early Albian of Près de Rencurel (Isère, SE France) presents, on more or less early stages, a recapitulation of the three morphological stages: the stage of Cheloniceras on early whorls (10-15 $\mathrm{mm}$ in diameter), then the stage Epicheloniceras (20-25 mm diameter) and at last the stage Douvilleiceras. This is easily observable on many specimens from the condensed series of the Vercors area, where the Douvilleiceras stage is preceded by an Eodouvilleiceras stage. The genus Eodouvilleiceras, described for transitional morphologies from Epicheloniceras to Douvilleiceras, could only represent an ontogenetic stage of earliest members of the genus
Douvilleiceras. Consequently, Eodouvilleiceras is herein considered as a synonym of Douvilleiceras.'

Riedel's original illustrations are reproduced here as Fig. 8. They are reduced, according to Riedel, $\times 0.9$. He gives the diameter of the holotype as $68 \mathrm{~mm}$. The present material shows the same ontogenetic stages as those noted by Latil (see above; Figs 9A-E, 10C, D), but the holotype of horridum differs in retaining an outer ventrolateral tubercle with a single groove dividing it into two spiral ridges to a much greater diameter than the present material, where up to three grooves and four ridges develop. A specimen from southwest of Ndumu (OUM KX9885: Fig. 17C, E), $45 \mathrm{~mm}$ in diameter bears a striking similarity to the holotype of horridum, but differs in developing two grooves and three spiral ridges from a diameter of around $35 \mathrm{~mm}$. It is also unclear from the figures if the holotype of horridum is a juvenile or an adult. Accordingly, it is treated as only a possible synonym of Douvilleiceras here. We note that Klein \& Bogdanova (2013, p. 55) refer 14 species to Eodouvilleiceras, without discussion.

There have been two very different approaches to the interpretation of Douvilleiceras species. The most comprehensive account to date is that of Casey (1962) who recognized 11 species and varieties from the Lower Albian of southern England, noted two species from the Middle Albian of the same area, and recognized six other species in the text. A species-rich Douvilleiceras is also indicated by Owen (1988, table on p. 209), who recognized 12 taxa from his Lower Albian mammillatum Superzone in Europe, with up to five taxa co-occurring in individual subzones. Cooper (1982) listed over 40 trivial names that had been applied to Douvilleiceras, noting that in addition to the co-occurrence of numerous species in British collections, Scott (1940) recognized 11 species in Texas, and Tavani $(1942,1949) 8$ in collections from Somalia. As Cooper noted, 'Casey's revision, coming at a time when it was the practice to base species on very narrowly defined limits, suffers from oversplitting .... in his revision of the British species of Douvilleiceras, [he] laid much emphasis on the width of the ventral sulcus, number of notches per rib, and the ontogenetic stage at which ornament change occurred as taxonomic criteria. However, many writers have noted that the number of notches increase with diameter, while Collignon (1963), Mirzoyev (1967), and McLearn (1972) have all reported specimens with different numbers of notches on opposed flanks. Consequently, this criterion is considered to be of very limited taxonomic significance.' Casey himself noted (1962, p. 263) that 'The eight species described below thus come from a limited range of strata, and they constitute a closely interconnected plexus that in former days would have been interpreted (perhaps correctly) as one large, highly variable species', and (1962, p. 282) that transitions between his Douvilleiceras alternans and Douvilleiceras orbignyi Hyatt, 1903, were not uncommon, referring to them as 'mongrels'.

In the revision of large collections of poorly preserved Douvilleiceras from the upper Lower Albian of Angola, Cooper recognized three taxa only: Douvilleiceras mammillatum aequinodum (Quenstedt, 1849), D. variabile Tavani, 1949, and D. inaequinodum (Quenstedt, 1849), noting (p. 281) that $D$. variabile might merely be a morphotype 
within a polytypic $D$. mammillatum, but that 'opposition to such gross 'lumping' that such synonymies would involve from one of the referee's of this paper had led to the adoption of a somewhat more cautious approach.'

In contrast, Amédro (1992) recognized only two Douvilleiceras species in the Anglo-Paris basin sequences, and suggested that there might in fact be but a single variable species, in which he recognized no significant morphological changes through time. In the latest review, Klein \& Bogdanova (2013) refer 44 species to the genus.

One of the difficulties faced by workers on Douvilleiceras has been that many of the classic faunas come from condensed phosphatic nodule beds, where nuclei and phragmocones dominate assemblages, as Casey (1962, p. 264) noted. The present material comes, in contrast, from expanded sequences that preserve nuclei, and both large and small adults. These show that many previous accounts have been based on a narrow interpretation of intraspecific variation, a failure to recognize dimorphism, as a consequence of which individuals of the same size, but at different ontogenetic stages have been compared, and different preservations. We recognize only two species of Douvilleiceras in the KwaZulu-Natal material.

\section{Occurrence}

Lower and lower Middle Albian, ranging from the Leymeriella regularis Zone to the Lyelliceras lyelli Subzone in terms of the northwest European sequence. The geographic distribution extends from southern England to France, Switzerland, Germany, the Helvetic Zone of western Austria, Poland, Bulgaria, Romania, Georgia, eastwards to Kazakhstan, Turkmenia, northern India, Pakistan, Japan, British Columbia, California, Arizona, New Mexico, and Texas in the United States, Peru, Colombia, Brazil, Tunisia, Algeria, Gabon, Angola, KwaZulu-Natal in South Africa, Mozambique, Somalia, and Madagascar.

\section{Douvilleiceras mammillatum (Schlotheim, 1813)}

Figs $1-4,6,7,9,10,11 \mathrm{~A}-\mathrm{C}, \mathrm{M}-\mathrm{O}, 12 \mathrm{~A}-\mathrm{F}, 13 \mathrm{~A}-\mathrm{H}, 14-18$, 21, 22A, B

1813 Ammonites mammillatus Schlotheim, p. 111.

1816 Ammonites monile J. Sowerby, p. 35, pl. 117, fig. 1 only.

1841 Ammonites Clementinus d'Orbigny, p. 260, pl. 75, figs 5, 6.

1849 Ammonites monile aequinodus Quenstedt, p. 137, pl. 10, fig. 2.

1878 Acanthoceras mammillare v. Schlotheim; Bayle, pl. 59, figs $1-3$.

1888 Ammonites mammillatus de Lapparent \& Fritel, pl. 59, figs 1-3.

1907 [Douvilleiceras sp.] Etheridge, p. 87, pl. 5, figs 1, 2.

1923 Douvilleiceras albense Spath, p. 70.

1930 Douvilleiceras mammillatum Schlotheim; Passendorfer, p. 651.

1942 Douvilleiceras monile (Sow.); Tavani, p. 119 (33), pl. 12 (3), fig. 10.

?1942 Douvilleiceras mammillatum (Schl.); Tavani, p. 119 (33).

1942 Douvilleiceras spinosum Tavani, p. 120 (34), pl. 13 (4), figs 1, 2; pl. 14 (5), figs 3, 4, 9.

1947 Douvilleiceras albense Spath; Breistroffer, p. 43 (27).

?1949 Douvilleiceras mammillatum (Schl.); Tavani, p. 109 (37).

?1949 Douvilleiceras monile (Sow.); Tavani, p. 109 (37).
1949

Douvilleiceras variabile Tavani, p. 109 (37), pl. 21 (10), figs 1, 2.

1949 Douvilleiceras cheloniceratiforme Tavani, p. 110 (38), pl. 19 (8), fig. 6.

1962 Douvilleiceras clementinum (d'Orbigny); Casey, p. 263, text-figs 91, 92.

1962 Douvilleiceras mammillatum (Schlotheim); Casey, p. 265, pl. 40, fig. 4; pl. 42, fig. 4; pl. 42, figs 6, 9, 10; text-fig. 102a, b (with synonymy).

1962 Douvillleiceras mammillatum (Schlotheim) var. aequinodum (Quenstedt); Casey, p. 271, pl. 40, fig. 5; pl. 41, figs 5-7; pl. 42, fig. 10; text-figs 94a-c, 95a-b, 102d, 103a-b (with synonymy).

1962 Douvilleiceras mammillatum (Schlotheim) var. praecox Casey, p. 272, pl. 41, fig. 8; text-figs 94d, e, 102c (with synonymy).

1962 Douvilleiceras scabrosum Casey, p. 278, pl. 40, figs 1-3; pl. 42, fig. 2; text-figs 102f, 1031.

1962 Douvilleiceras monile (J. Sowerby); Casey, p. 284 pl. 41, figs 2a, b; pl. 42, fig. 5; text-fig. 102e (with additional synonymy).

1963 Douvilleiceras mammillatum (Schloth.); Collignon, p. 109, pl. 283, figs 1238-1239, 1241; pl. 284, fig. 1242.

1963 Douvilleiceras albense Spath; Collignon, p. 112, pl. 284, fig. 1243.

1967 Douvilleiceras subleightonense Mirzoyev, p. 64, pl. 8, figs 1-3; text-fig. 4.

1969 Douvilleiceras mammillatum (Schlotheim); Obata, p. 172, pl. 19, figs 3,5

1973 Douvilleiceras spiniferum (Whiteaves); McLearn, p. 62 (pars), pl. 10, fig. 3.

1979 Douvilleiceas mammillatum mammillatum (Schlotheim), Casey, 1962; Destombes. p. 69, pl. 4-21, fig. 1.

1979 Douvilleiceras mammillatum var. aequinodum (Quenstedt); Destombes, p. 71, pl. 4-4, fig. 1; pl. 4-5, fig. 2; pl. 4-21, fig. 2.

1979 Douvilleiceras mammillatum var. praecox Casey; Destombes, p. 71, pl. 4-21, fig. 3.

1979 Douvilleiceras perchoisense Destombes, p. 72, pl. 4, fig. 2.

1979 Douvilleiceras aff. scabrosum Casey, 1962; Destombes, p. 73, pl. 4-5, fig. 3.

1979 Douvilleiceras clementinum d'Orbigny, 1841; Destombes, p. 74.

?1980 Douvilleiceras mammillatus (Schloth.); Krishna, p. 51, non pl. 1, figs 2, 6, 7 .

1981 Douvilleiceras mammillatum (Schlotheim); Chiriac, p. 86, pl. 17, fig. 1.

?1981 D. inaequicostatum Chiriac, p. 87, pl. 18, fig. 3; text-fig. 36.

?1981 Douvilleiceras monile (J. Sowerby); Chiriac, p. 86, pl. 13, fig. 3.

1982 Douvilleiceras mammillatum var. aequinodum (Quenstedt, 1849); Cooper, p. 272, figs 4a,b, 6c-g, 7d, g-l', $8 a, b "$ " 9a-c, e, 10c, d, 12a, b, 17a (with additional synonymy).

1983 Douvilleiceras mammillatum (Quenstedt); Weidich, Schwerd \& Immel, p. 566, pl. 2, fig. 6.

1986 Douvilleiceras sp. juv.; Kennedy, text-fig. 2. 8-16.

1988 Douvilleiceras mammillatum (Schlotheim); Owen, text-fig. 31. 
1988

1988

Douvilleiceras perchoisense Destombes; Owen, p. 210.

Douvilleiceras mammillatum praecox Casey; Owen, p. 211.

1990 Douvilleiceras mammillatum (Schlotheim); Marcinowski \& Wiedmann, p. 51, pl. 7, figs 5, 6

1996 Douvilleiceras mammillatum (Schlotheim); Wright, p. 269, text-fig. 209.2

1997 Douvilleiceras mammillatum mammillatum (Schlotheim, 1813); Kennedy in Kennedy, Bilotte \& Hansotte, p. 469, pl. 6, figs 20, 21 .

1997 Douvilleiceras aff. mammillatum (Schlotheim, 1813); Immel, Seyed-Emami \& Afshar-Harb, p. 184, pl. 7, fig. 3.

1997 Douvilleiceras sp. ex. gr. D. monile (Sowerby 1816); Immel, Seyed-Emami \& Afshar-Harb, p. 184, pl. 7, fig. 2.

2005 Douvilleiceras mammillatum (Schlotheim); Topchisvilli, p. 389, pl. 98, fig. 1; pl. 99, fig. 1.

2006 Douvilleiceras clementinum (d'Orbigny, 1841) Guérin-Franiatte in Gauthier, p. 94, pl. 38, fig. 4.

2007 Douvilleiceras mammillatum (Schlotheim 1813); Szives, p. 122, pl. 22, fig. 3.

2008 Douvilleiceras mammillatum aequinodatum (Quenstedt 1849); Latil, p. 257, pl. 2, figs 4, 5 (with additional synonymy).

2010 Douvilleiceras gr. mammillatum (Schlotheim, 1813); Matrion in Colleté, p. 182, text-fig. 127 c, d.

2010 Douvilleiceras clementinum (d'Orbigny, 1841); Matrion in Colleté, p. 182, text-fig. 127b; 128e; 129a.

2013 Douvilleiceras albense Spath, 1923; Klein \& Bogdanova, p. 59 (with additional synonymy).

2013 Douvilleiceras cheloniceratiforme Tavani, 1949; Klein \& Bogdanova, p. 64.

2013 Douvilleiceras clementinum (d'Orbigy, 1841); Klein \& Bogdanova, p. 60 (with additional synonymy).

2013 Douvilleiceras mammillatum aequinodum (Quenstedt, 1849); Klein \& Bogdanova, p. 63 (with additional synonymy).

2013 Douvilleiceras mammillatum mammillatum (Schlotheim, 1813); Klein \& Bogdanova, p. 64 (with additional synonymy).

2013 Douvilleiceras mammillatum praecox Casey, 1962; Klein \& Bogdanova, p. 68 (with additional synonymy).

2013 Douvilleiceras monile J. Sowerby, 1816); Klein \& Bogdanova, p. 68 (with additional synonymy).

2013 Douvilleiceras perchoisense Destombes, 1979; Klein \& Bogdanova, p. 63.

2013 Douvilleiceras scabrosum Casey, 1962; Klein \& Bogdanova, p. 63 (with additional synonymy).

2013 Douvilleiceras spinosum Tavani, 1942; Klein \& Bogdanova, p. 63.

2013 Douvilleiceras subleightonense Mirzoyev, 1967; Klein \& Bogdanova, p. 73.

2013 Douvilleiceras variabile Tavani, 1942; Klein \& Bogdanova, p. 73.

2014 Douvilleiceras clementinum (d'Orbigny, 1841); Amèdro, Matrion, Magniez-Jannin \& Touch, pl. 3.

Type

The neotype is no. C12491 in the collections of the Natural History Museum, London, figured by Casey, 1962, pl. 41, fig. 4, from the condensed Lower Albian Cleoniceras floridum Subzone-Otohoplites raulinianus Subzone fauna, foreshore outcrops at Copt Point, Folkestone, Kent. It is illustrated here as Fig. 3.

\section{Material}

OUM KX10994-11016, 11019-22, from locality 35. OUM KX11052-56, from locality 36. OUM KX4851-2, 4855-7, 4862, 4865-6, 4868, 4872-5, 4878, 4883-87, from locality 53. OUM KX6148-9, 6151, from locality 142. OUM KX9298, 9300, and 9302-3, from locality 154. OUM KX9922, 9923, 9924/9927 (parts of the same specimen), 9925-6, 9928-32, and 12643, from locality 174 . OUM KX9941, 9943, 9950, and 10035 from locality 175. OUM KX10005-13, 10015-6, 10016, and 12379, from locality 176. OUM KX9881-9885, 9888-9, 9892, and 12608, from southwest of Ndumu.

\section{Description}

Selected specimens are described below by locality number. Material from locality 35 . There are 27 specimens.

\begin{tabular}{|l|c|c|c|c|c|}
\hline & $\mathrm{D}$ & $\mathrm{Wb}$ & Wh & Wb:Wh & $\mathrm{U}$ \\
\hline OUM KX10999c & $\begin{array}{c}42.0 \\
(100)\end{array}$ & $\begin{array}{c}26.4 \\
(62.9)\end{array}$ & $\begin{array}{c}18.1 \\
(43.1)\end{array}$ & 1.46 & $\begin{array}{c}12.5 \\
(29.8)\end{array}$ \\
\hline OUM KX11012c & $\begin{array}{c}42.6 \\
(100)\end{array}$ & $\begin{array}{c}24.0 \\
(56.3)\end{array}$ & $\begin{array}{c}17.3 \\
(40.6)\end{array}$ & $1.39)$ & $\begin{array}{c}14.2 \\
(33.3)\end{array}$ \\
\hline OUM KX11011c & $\begin{array}{c}43.1 \\
(100)\end{array}$ & $\begin{array}{c}24.6 \\
(57.1)\end{array}$ & $\begin{array}{c}18.7 \\
(43.4)\end{array}$ & 1.32 & $\begin{array}{c}14.2 \\
(32.9)\end{array}$ \\
\hline OUM KX11008 & $\begin{array}{c}51.6 \\
(100)\end{array}$ & $\begin{array}{c}27.9 \\
(54.10\end{array}$ & $\begin{array}{c}21.4 \\
(41.5)\end{array}$ & 1.3 & $\begin{array}{c}16.9 \\
(32.8)\end{array}$ \\
\hline
\end{tabular}

OUM KX 10995-6, 10998,11012, and 10119-11022 preserve early growth stages between 16.8 and $24.8 \mathrm{~mm}$. OUM KX11021, $16.8 \mathrm{~mm}$ in diameter (Fig. 9A-C), has, at the adapical end of the outer whorl, widely separated, barely detectable prorsiradiate primary ribs on the inner flank that strengthen into massive conical inner ventrolateral tubercles that are the bases of septate spines (preserved in one instance in OUM KX10995: Fig. 9D, E) these give rise to a narrow rib that passes straight across the venter, and bears a feeble outer ventrolateral bulla. The first two of these ribs is succeeded by a shallow ventral constriction. The primary ribs are separated by single intercalated ribs that arise on the ventrolateral shoulder, and bear outer ventrolateral bullae only. There are 10-11 primary ribs, and a total of 15 ribs at the ventrolateral shoulder on the outer whorl of this specimen. On the adapertural most of the primary ribs, a tiny, incipient umbilical bulla is present. In OUM KX 11019, $23 \mathrm{~mm}$ in diameter, a median groove appears on the outer ventrolateral tubercles of the last few ribs, dividing them into two spiral ridges. OUM KX10998 (Fig. 10C, D), $25.1 \mathrm{~mm}$ in diameter, shows the progressive strengthening of the umbilical bullae. OUM KX10999 (Figs 10E-G, 14A-C), has a depressed reniform whorl section with an intercostal whorl breadth to height ratio of 1.4. There are nine coarse, straight, prorsiradiate ribs on the adapertural half of the outer whorl, most of them primaries, with small umbilical bullae, and all with strong, conical inner ventrolateral tubercles (the bases of septate spines) 
and a strong outer ventrolateral bulla. This is divided into two spiral ridges by a groove on the adapical part of the outer whorl, and into three spiral ridges by two grooves, the second groove developing on the outer side of the outer ventrolateral bulla, on the adapertural half of the outer whorl. There is a well-developed dorsal callosity on the adapical $120^{\circ}$ sector of the outer whorl (Fig. 10E).

OUM KX11011 (Fig. 9F-H) is a finely ornamented individual with a maximum preserved diameter of $43.2 \mathrm{~mm}$. There are 23-24 primary ribs on the outer whorl, together with occasional long intercalated ribs. The ribs are narrow, straight and prorsiradiate, the primaries with weak umbilical bullae. The ribs bear sharp septate inner ventrolateral spines where shell is preserved as on the adapical part of the outer whorl, and these are stronger than the umbilical bullae. On the adapical part, where shell is absent, there are inner ventrolateral bullae, only slightly stronger than the umbilical. The outer ventrolateral bulla of the earlier ontogenetic growth stages is assimilated into the rib, the outer part of the ventrolateral shoulder bearing four small spirally elongated clavi. The mid-ventral region is concave in intercostal section. OUM KX11008 (Fig. 9M, N) is a coarsely ornamented individual $55.2 \mathrm{~mm}$ in diameter. There are 21 ribs on the outer whorl. They arise at the umbilical seam, and most bear a small, but progressively strengthening umbilical bulla, a larger, conical inner ventrolateral spine base, and a strong outer ventrolateral tubercle, divided into three spiral ridges by two grooves, the ridges strengthening progressively towards the mid- venter, which is deeply concave. The adapertural three ribs bear a feeble inner lateral tubercle. The largest specimen from this locality is OUM KX11010 (Fig. 9K, L), an internal mould of a $240^{\circ}$ body chamber, the original estimated diameter of the specimen $75 \mathrm{~mm}$. There are ten primary ribs on the specimen, arising at the umbilical seam, sweeping back across the umbilical wall and developing into an umbilical bulla of variable strength, the bullae in some cases flat-topped, suggesting they may have been the septate base of a spine, now lost. The relatively coarse ribs bear a weak inner lateral bulla, a stronger inner ventrolateral spine base, and four progressively strengthening clavi on the ventrolateral shoulder. There are three single weak intercalated ribs between successive primaries on the adapical part of the specimen, one with a minute outer ventrolateral bulla. Of the five larger specimens, $40-75 \mathrm{~mm}$ in diameter in the assemblage, six belong to this coarse ribbed variant, with a single finer-ribbed individual (OUM KX11011).

Material from locality 53. There are 19 specimens, many of them fragments, with whorl heights of between 13 and $46 \mathrm{~mm}$, all retaining recrystallized shell.

\begin{tabular}{|l|c|c|c|c|c|}
\hline & $\mathrm{D}$ & $\mathrm{Wb}$ & $\mathrm{Wh}$ & $\mathrm{Wb} ; \mathrm{Wh}$ & $\mathrm{U}$ \\
\hline OUM KX4872c & $\begin{array}{c}52.2 \\
(100)\end{array}$ & $\begin{array}{c}27.7 \\
(53.0)\end{array}$ & $\begin{array}{c}22.5 \\
(43.1)\end{array}$ & 1.23 & $\begin{array}{c}16.9 \\
(32.4)\end{array}$ \\
\hline OUM KX4855 & $\begin{array}{c}70.4 \\
(100)\end{array}$ & $\begin{array}{c}39.3 \\
(55.8)\end{array}$ & $\begin{array}{c}31.0 \\
(44.0)\end{array}$ & 1.27 & $\begin{array}{c}22.6 \\
(32.1)\end{array}$ \\
\hline OUM KX4856c & $\begin{array}{c}68.3 \\
(100)\end{array}$ & $\begin{array}{c}39.3 \\
(57.5)\end{array}$ & $\begin{array}{c}33.6 \\
(49.2)\end{array}$ & 1.17 & $\begin{array}{c}21.9 \\
(32.1)\end{array}$ \\
\hline
\end{tabular}

All specimens are whole or fragmentary phragmocones, the largest fragment corresponding to an original estimated diameter of $120 \mathrm{~mm}$ approximately. Coiling is involute, the umbilicus deep, the feebly convex umbilical wall notched to accommodate the septate inner ventrolateral spines of the preceding whorl, the umbilical shoulder broadly rounded. The intercostal whorl section is depressed reniform, with whorl breadth to height ratio of up to 1.25 . OUM KX4872 (Fig. 11M-O) is $52.2 \mathrm{~mm}$ in diameter. There are 21-22 ribs on the outer whorl, all primaries that arise at the umbilical seam and strengthen across the umbilical wall and shoulder, where most but not all develop into a small bulla. The ribs are straight and feebly prorsiradiate on the flanks, and pass straight across the venter. They strengthen across the flanks, and develop into small conical inner ventrolateral tubercles that are the bases of septate spines, well preserved on the penultimate whorl, while an additional row of inner lateral tubercles appear and strengthen over the adapical $120^{\circ}$ sector of the outer whorl. The ribs strengthen further across the ventrolateral shoulders, where five small spirally elongated clavi are separated by grooves. A strong transverse rib links the tubercles across the venter, which is concave in intercostal section. The ventrolateral shoulders dorsal of the inner ventrolateral tubecles and the venter of the adapical half of the outer whorl are covered by the dorsal callosity of the now missing succeeding whorl (Fig. 11N). OUM KX4855, although worn, has over 30 finer, more delicate ribs on the outer whorl, the umbilical and inner ventrolateral tubercles subequal, and has developed an inner lateral tubercle from the beginning of the outer whorl. OUM KX4856 is a coarser ribbed individual with 20 primary ribs on the outer whorl, the umbilical bullae of varying strength, and occasional non-bullate primaries/long intercalated ribs to give a total of 24 ribs at the ventrolateral shoulder. The inner ventrolateral tubercle is stronger than the umbilical at the beginning of the outer whorl but weakens progressively with the umbilical bullae stronger than the inner lateral and inner ventrolateral tubercle on the adapertural part of the outer whorl. There are clearly differentiated outer ventrolateral bullae on the adapical part of the outer whorl, divide into four spiral ridges separated by three grooves, but as size increases bullae are replaced by a strengthened ventrolateral rib bearing five clavi separated by grooves, derived from the grooves and ridges on the outer ventrolateral bulla on the adapical part of the whorl. The largest fragments (OUM KX4862, 4865, 4878: Fig. 12A-F) show the weakening and eventual disappearance of the ventral sulcus in the costal section, and the narrowing of the relatively wide separation between the outermost of the tubercles on either side of the venter, with eight tubercles on the ribs on either side. There are 13 finely ribbed specimens and three slightly more coarsely ribbed specimens (OUM KX4856: Fig. 11A-C) in the assemblage.

Material from locality 142. There are three specimens. OUM KX 6151 is a well-preserved $60^{\circ}$ sector of juvenile phragmocone retaining recrystallized shell, with a maximum preserved costal whorl height of $17 \mathrm{~mm}$. Six ribs are preserved on the fragment. There are three primaries with strong umbilical bullae, stronger inner ventrolateral spine bases, and three spiral ridges separated by grooves on the outer ventrolateral bulla. The three long intercalated ribs alternate regularly with the primaries, and bear very feeble inner ventrolateral tubercles, the outer ventrolateral tuberculation 
as on the primary ribs. The ventral sulcus in the costal section is relatively wide. OUM KX6149 (Fig. 13G) is an internal mould of a $120^{\circ}$ sector of phragmocone with a maximum preserved whorl height of $36.3 \mathrm{~mm}$ and a whorl breadth to height ratio of 1.18. Fourteen ribs are preserved on the fragment. Seven are primaries, with small umbilical bullae, feeble inner lateral bullae, and conical inner ventrolateral tubercles. The ventrolateral shoulders bear four rows of small clavi; there is no mid-ventral sulcus. The long intercalated ribs lack an umbilical bulla, and have a similar ventrolateral ornament to the primaries. OUM KX6148 (Fig. 13E, F) is a $43 \mathrm{~mm}$ nucleus and an internal mould of a $120^{\circ}$ sector of body chamber with a maximum preserved whorl height of $37 \mathrm{~mm}$ and a whorl breadth to height ratio of 1.16. There are 13 ribs on the fragment, eight of them primaries. The ribs arise at the umbilical seam and strengthen across the umbilical wall to link to well-developed umbilical bullae that project into the umbilicus. They are straight, prorsiradiate, flat-topped, widening progressively across the flanks, and separated by relatively deep, narrow interspaces. There are small conical inner lateral and inner ventrolateral tubercles, and six rows of clavi on the ventrolateral shoulder, the mid-ventral sulcus narrow. Intercalated ribs lack an umbilical, and sometimes an inner lateral tubercle, but have a ventrolateral ornament matching that of the primary ribs.

Material from locality 174 . There are 10 specimens.

\begin{tabular}{|l|c|c|c|c|c|}
\hline & $\mathrm{D}$ & $\mathrm{Wb}$ & $\mathrm{Wh}$ & Wb:Wh & $\mathrm{U}$ \\
\hline OUM KX9931c & $\begin{array}{c}52.1 \\
(100)\end{array}$ & $\begin{array}{c}26.9 \\
(51.6)\end{array}$ & $\begin{array}{c}22.1 \\
(42.4)\end{array}$ & 1.22 & $\begin{array}{c}17.0 \\
(32.6)\end{array}$ \\
\hline OUM KX9932c & $\begin{array}{c}57.3 \\
(100)\end{array}$ & $\begin{array}{c}31.2 \\
(54.5)\end{array}$ & $\begin{array}{c}23.1 \\
(40.3)\end{array}$ & 1.35 & $\begin{array}{c}19.0 \\
(33.2)\end{array}$ \\
\hline OUM KX9930c & $\begin{array}{c}68.7 \\
(100)\end{array}$ & $\begin{array}{c}34.9 \\
(50.1)\end{array}$ & $\begin{array}{c}28.5 \\
(41.5)\end{array}$ & 1.22 & $\begin{array}{c}22.7 \\
(33.0)\end{array}$ \\
\hline OUM KX9929c & $\begin{array}{c}73.9 \\
(100)\end{array}$ & $\begin{array}{c}40.9 \\
(1.21)\end{array}$ & $\begin{array}{c}32.9 \\
(44.5\end{array}$ & 1.24 & $\begin{array}{c}21.6 \\
(29.2)\end{array}$ \\
\hline OUM KX9924c & $\begin{array}{c}81.9 \\
(100)\end{array}$ & $\begin{array}{c}40.5 \\
(49.5)\end{array}$ & $\begin{array}{c}37.1 \\
(45.2)\end{array}$ & 1.09 & 24.8 \\
\hline
\end{tabular}

Many of the specimens retain partially exfoliated shell. OUM KX9926 (Fig. 10A, B) is a well-preserved nucleus $33.2 \mathrm{~mm}$ in diameter. There are 10 ribs on the outer half whorl, with very strong conical inner ventrolateral bases to septate spines, and larger outer ventrolateral tubercles, divided into two spiral ridges by a groove. OUMKX9932 (Fig. 15E, F), with a maximum preserved diameter of $57.3 \mathrm{~mm}$ has, throughout the outer whorl, a progressively strengthening umbilical bulla that is weaker than the inner ventrolateral, with the outer ventrolateral tubercle divided into three spiral ridges, separated by grooves. There is a single weaker, intercalated rib at the greatest preserved diameter. OUM KX9931, $66.7 \mathrm{~mm}$ in maximum preserved diameter, and OUM KX9930 (Fig. 14D-F), $72.2 \mathrm{~mm}$ in maximum preserved diameter, both show the appearance of a feeble inner lateral tubercle, and the assimilation of the outer ventrolateral bulla into the ventrolateral part of the rib, the spiral ridges of the earlier ontogenetic stages strengthened into clavi, with the addition of fourth row. OUM KX9922 (Fig. 14I) is an incomplete nucleus $55 \mathrm{~mm}$ approximately in diameter, and a half whorl of crushed body chamber with an estimated diameter of $140 \mathrm{~mm}$; it is inter- preted as an incomplete macroconch. The penultimate whorl has primary ribs with well-developed small umbilical bullae, a smaller inner lateral tubercle at the greatest preserved diameter, and well-preserved inner ventrolateral spines. The adapical end of the outer whorl fragment is phragmocone, the greater part is body chamber. On the phragmocone fragment, the primary ribs bear umbilical bullae, a weak inner lateral tubercle, stronger inner ventrolateral, and four narrow clavi on the outer part of the ventrolateral shoulder. OUM KX12643 (Fig. 6) is the phragmocone of a macroconch $195 \mathrm{~mm}$ in diameter. A somewhat battered individual, the primary rib at the adapical end of the outer whorl with an umbilical bulla, stronger inner ventrolateral tubercle, and four rows of spiral ridges borne on the outer ventrolateral bulla which is thereafter assimilated into the rib, the ventral costal rib profile changing from markedly sulcate to rounded and feebly convex, lateral, then ventrolateral tubercles effacing, leaving only umbilical bullae on crowded, rounded prorsiradiate ribs that strengthen across outer flanks, ventrolateral shoulders and venter, which the ribs cross near-transverse OUM KX9924/7 (Fig. 15A-C: OUM KX9924 and 9927 are fragments of the same specimen) and 9929 (Fig. 14G, H) are closely comparable individuals, with up to $240^{\circ}$ of outer whorl preserved, most or all of which is body chamber; they are interpreted as near-complete microconchs. Ornament is of coarse crowded ribs, most of them primaries, with occasional long intercalated ribs, separated by deep interspaces. In OUM KX 9924/7, there are 14-15 primaries and 28 ribs in total on the $240^{\circ}$ sector of body chamber preserved. On the adapical part, the primary ribs bear nine rows of tubercles, the umbilical, inner lateral and inner ventrolateral rounded-conical, the ventrolateral rows clavate, the ventral sulcus narrow. On the adapertural part, the ribs crowd, the umbilical bullae and flank tubercles are lost, the tubercles on the ventrolateral shoulders weaken markedly, and the ribs pass straight across the venter, with a tabulate profile in costal section, rather than sulcate as on the adapical most part. In OUM KX9929 (Fig. 14G, H) the ventral sulcus is wider at the adapical end of the body chamber, with a total of eight rows of tubercles. towards the adapertural end of the fragment a row of very feeble siphonal clavi appear, and the ventral sulcus is eliminated.

Material from locality 175. There are four specimens. OUM KX9943 (Fig. 16A, B) is a fragment with an estimated original diameter of $92 \mathrm{~mm}$ retaining extensive areas of original shell material; the adapertural $90^{\circ}$ sector is body chamber. This is a relatively weakly tuberculate individual, with a broad, shallow ventral sulcus in costal section. OUM KX9941 (Fig. 13H) is a very well-preserved ventral region of a body chamber fragment retaining partially exfoliated, limonitized shell material. The ventral sulcus is narrow, with five rows of subequal ventrolateral clavi visible.

Material from locality 176 . There are 13 specimens.

OM KX10009, 10015, and 12379 (Fig. 13C, D) are relatively weakly tuberculate individuals; OUM KX12379 is the best-preserved, with a diameter of $60 \mathrm{~mm}$, retaining original shell material. It has a $240^{\circ}$ sector of body chamber, and is interpreted as an adult microconch, the smallest in the KwaZulu material. There are small umbilical, and larger 
inner ventrolateral spines on the primary ribs on the phragmocone, and four rows of clavi on the ventrolateral shoulder,the ventral sulcus wide and very shallow. This style of ornament extends onto the adapical part of the body chamber, where there are long intercalated ribs with no, or very weak tubercles. On the adapertural part, the umbilical and inner ventrolateral spines persist, the ventrolateral clavi weakened. OUM KX10010 (Fig. 13A, B) is a rather worn finely ribbed variant, with $180^{\circ}$ of body chamber preserved. OUM KX 10007 (Fig. 14J, K) consists of a $45 \mathrm{~mm}$ approximately nucleus with a well-preserved $120^{\circ}$ sector of body chamber retaining original shell material. It is interpreted as a microconch. The maximum preserved whorl height is $34 \mathrm{~mm}$; the whorl breadth to height ratio 1.26 at the adapical end. The ribs are wider than the interspaces on the body chamber, with 12 primaries and only two long intercalated ribs. There are conical umbilical and inner ventrolateral tubercles/spine bases, inner lateral bullae, and six rows of subequal clavi on the ventrolateral shoulder, the ventral sulcus narrow.

Material from southwest of Ndumu. There are nine specimens.

OUM KX9885 (Fig. 17C-E) is a phragmocone $46 \mathrm{~mm}$ in diameter. At the adapical end, the distant primary ribs bear umbilical, inner and outer ventrolateral tubercles, the outer ventrolateral tubercles bearing a pair of spiral ridges, separated by a median groove. As diameter increases, occasional weak intercalated ribs appear, and a second groove appears on the outer ventrolateral tubercle to give three ridges from a diameter of $35 \mathrm{~mm}$ onwards. OUM KX9883 (Fig. 17A, B) and 98834 show the same ontogenetic sequence, bearing umbilical bullae, inner lateral tubercles, inner ventrolateral spine bases, and four rows of narrow clavi on the ventrolateral shoulder at the greatest preserved diameter of $71 \mathrm{~mm}$. OUM KX9881 (Fig. 17F, G), with a maximum preserved diameter of an estimated $80 \mathrm{~mm}$ is a near-complete microconch, with the relatively coarse ornament as that of OUM KX9883 on the adapertural part of the phragmocone, with four rows of spiral ridges on an outer ventrolateral bulla, the mid-venter deeply sulcate in costal section visible on three ribs preceding the damaged part of the specimen. The ribs are relatively narrow on the $240^{\circ}$ sector of body chamber present. At the adapical end, the outer ventrolateral bulla has been assimilated into the rib and there are subequal umbilical inner lateral and inner ventrolateral tubercles, together with six rows of ventrolateral clavi, the mid-ventral sulcus narrow and shallow. Ribs and tubercles weaken towards the aperture, the ventral sulcus is no wider nor deeper than the distance between adjacent clavi, with relatively narrow ribs bearing up to seven rows of ventrolateral clavi to give ten rows of tubercles on each rib, the flank rows effaced on the last few ribs, indicating maturity.

OUM KX9882 (Fig. 16C, D) is an internal mould of a phragmocone $91 \mathrm{~mm}$ in diameter. It has relatively massive whorls compared with other specimens from this locality, the whorl breadth to height ratio 1.22 . The ribs are weak and crowded. At the adapertural end there are small, damaged umbilical and inner lateral spines, small inner lateral bullae, and five rows of ventrolateral clavi, the mid-ventral sulcus no wider than the spaces between adjacent clavi.

\section{Discussion}

The neotype of Douvilleiceras mammillatum, BMNH C12491(Fig. 3) is a phosphatized internal mould retaining extensive traces of phosphatized shell. The position of the last septum is difficult to establish, but there appears to be just over $180^{\circ}$ of body chamber present, the specimen being an incomplete adult microconch. The dimensions are:

D: 80.0 (100); Wb: 42.1 (52.6); Wh: 32.6 (40.7); Wb:Wh: 1.29; U: 27.8 (34.8)

There are 13 ribs on the adapical half whorl; a maximum of 22 ribs can be counted on the specimen, and the total number of ribs on the outer whorl is estimated at between 25 and 26. The ribs at the adapical end of the outer whorl bear a small umbilical bulla, a subequal rounded inner lateral tubercle, a larger, conical inner ventrolateral tubercle, and a long outer ventrolateral bulla, divided into four spiral ridges by three spiral grooves, the mid-venter markedly sulcate in costal section. This ornament extends onto the adapical part of the body chamber, beyond which the ventrolateral bulla weakens and effaces, the spiral ridges now ventral clavi. At the greatest preserved diameter, there is a ventral sulcus in costal section that is only slightly deeper than that between the clavi. At this stage, there are umbilical bullae, conical inner lateral and inner ventrolateral tubercles, and five rows of clavi on the ventrolateral shoulder. Specimens from northern KwaZulu-Natal that correspond to the neotype include individuals that extend to the adult aperture, with a progressive increase in the number of rows of ventrolateral clavi and decline and effacement of tubercles, where ribbing comes to dominate, interpreted as adult microcochs as little as $80 \mathrm{~mm}$ (OUM KX9881: Fig. 17F, G) to $87 \mathrm{~mm}$ in diameter (OUM KX9924: Fig. 15A-C), and others such as OUM KX 12643 (Fig. 6), still septate at $195 \mathrm{~mm}$ in diameter and interpreted as the phragmocone of a macroconch. The body chamber of OUM KX10007 (Fig. 14J, K) shows the development of six rows of ventrolateral clavi, and a very narrow mid-ventral sulcus, as does OUM KX6148 (Fig. 13E, F), also a body chamber. A further body chamber fragment,OUM KX 9941 (Fig. 13H) has a very narrow mid-ventral sulcus and five rows of ventrolateral clavi. In OUM KX 9881 (Fig. 17F, G), a seventh row of ventrolateral clavi develops on the body chamber, and the ventral sulcus is no wider than other interspaces between clavi. In OUM KX6149 (Fig. 13G), the mid-ventral sulcus is barely distinguishable from other interspaces on a phragmocone fragment, as in OUM KX4862 (Fig. 12E, F). Increase in numbers of rows of clavi and rows of the distinctive mid-ventral sulcus is a feature of microconch body chambers, and at least some fragments of presumed macroconch phragmocone.

The lectotype of Douvilleiceras monile (J. Sowerby, 1816) is BMNH 43941a, the original of J. Sowerby (1816, pl. 117, fig. 1), said to be from Sandgate, near Folkestone, Kent, but as Casey (1962, p. 288) notes, the preservation suggests that it is from the classic main mammillatum phosphate bed at Folkestone that is the source of the neotype of $D$. mammillatum. It is illustrated here as Fig. 18. It is a phosphatized phragmocone, $60 \mathrm{~mm}$ approximately in diameter when complete. There are 14 ribs, predominantly primaries, on the adapertural half of the outer whorl, with umbilical, bullae, conical inner lateral and inner ventrolateral tubercles, 
the ribs strengthened on the ventrolateral shoulder at the adapical end of the outer whorl, with three clavi separated by two spiral grooves. As size increases, a third groove appears, so that there are four spiral ridges, the inner very weak. Spath (1923, p. 72) noted that Douvilleiceras monile was connected to $D$. mammillatum by 'many transitions', but Casey (1962, p. 288) spoke of it as 'a rare and inadequately known species'. We regard it as a variant of $D$. mammillatum.

Douvilleiceras clementinum (d'Orbigny, 1841) (p. 260, $\mathrm{pl} .75$, figs 5,6 ) was introduced on the basis of single individual $400 \mathrm{~mm}$ in diameter, from the environs of Saint-Florentin (Yonne, France), collected by one Clément Mullet, and housed in the Musée de Troyes. The specimen has not been traced, and Guérin-Franiatte (in Gauthier 2006, p. 94, pl. 38, fig. 4) designated a neotype, no. 5789a-1 in the d'Orbigny collection, housed in the Laboratoire de Paléontologie of the Muséum National d'Histoire Naturellle, Paris. It is an incomplete macroconch $210 \mathrm{~mm}$ in diameter, from the lower Middle Albian lyelli Subzone Gault of Dienville, Aube, France. A much better preserved individual from Yonne, BMNH 47010 was figured by Casey (1962, text-fig. 91), with a maximum preserved diameter of $200 \mathrm{~mm}$, and also an incomplete macroconch. These specimens differ in no significant respects from adult macroconch $D$. mammillatum phragmocones from northern KwaZulu-Natal, apart from preservation, the Aube specimens retaining recrystallized shell and umbilical and inner ventrolateral spines. The specimen figured by Bayle (1879, pl. 59, fig. 1: Fig. 7) from Dienville, Aube, and thus a topotype of clementinum, is just over $130 \mathrm{~mm}$ in diameter. It is interpreted as the inner whorls of a macroconch. There are 24 small umbilical spines on the outer whorl, feeble inner lateral bullae, strong inner ventrolateral spines, and five rows of feebly clavate ventrolateral tubercles, and a narrow, shallow mid-ventral sulcus. This is the pattern of tuberculation shown by OUM KX9923 (Fig. 15D, G) at the same size. The earlier growth stages of $D$. clementinum from Dienville are represented, according to Casey (1962, p. 263), by the holotype of Douvilleiceras albense Spath, 1923 ( p. 70). The holotype is SMC F7727, figured by Casey (1962, text-fig. 92 on p. 263). His illustration is reproduced here as Fig. 4; the specimen was not available to us for study. The figures show an individual $86 \mathrm{~mm}$ in diameter, with 24 umbilical spines, giving rise to single ribs with occasional long intercalated ribs appearing on the apertural part of the outer whorl to give an estimated 28 ribs at the ventrolateral shoulder. There are well developed but progressively weakening inner ventrolateral spines, with weak inner lateral tubercles seemingly present only at the greatest preserved diameter, and five rows of ventrolateral clavi, the mid-ventral sulcus narrow, a weak siphonal row appearing at the greatest preserved diameter. The changes in ornament around the outer whorl suggest the specimen to be an incomplete adult microconch. Individuals close to the holotype of $D$. albense occur in KwaZulu material from localities 53, 142, 175, and 176, localities that either span the Lower/Middle Albian boundary, or are low in the Middle Albian. They are mostly individuals retaining body chamber, the mid-ventral sulcus narrow, with a feeble siphonal clavus appearing in some, as with OUM KX9929 (Fig. 14G, H), a slender individual compared with the holotype of albense. We regard these specimens, and the type material of both $D$. clementinum and $D$. albense, as late forms of a variable $D$. mammillatum.

Douvilleiceras solitae (d'Orbigny, 1853) (p. 211, pl 4, figs 1, 2, reproduced as Fig. 19 herein) was based on a specimen $100-110 \mathrm{~mm}$ in diameter from the côte de Petaquero of Nouvelle Grenade, that is say to Colombia. The inner whorls of the figure bear no resemblance to any Douvilleiceras known to us, but the outer whorl is more convincing, portraying a very evolute Douvilleiceras with six rows of tubercles. The species was revised by Etayo-Serna (1979, p 54, pl. 7, figs 6, 7; text-fig. 6j), who described it as bearing three rows of spiniform tubercles and three rows of clavi on the ventrolateral shoulder, on the adapical part of the outer whorl of a specimen an estimated $93 \mathrm{~mm}$ in diameter, the ventrolateral clavi increasing to five on the adapertural part of the outer whorl. Both Douvilleiceras tarapacaense Etayo-Serna, 1979 (p. 54, pl. 7, fig. 5; pl. 8, figs 2, 6; text-fig. 6c, g) and D. abozagloi Etayo-Serna, 1979 (p. 55, pl. 8, fig. 7), which co-occur with D. solitae in Etayo-Serna's Lower Albian Douvilleiceras solitae-Neodeshayesites coumbianus Zone of the Capotes member of central Colombia appear to be intraspecific variants. The very evolute coiling and less massive whorls of $D$. solitae and its synonyms separate them from D. mammillatum.

Casey (1962, p 274) compared Douvilleiceras invernoisi (Coquand, 1865) (p. 50; see Fig. 20) with D. leightonense Casey, 1962 (p. 274, pl. 41, fig. 1; pl. 42, fig. 3; text-figs 96, 97, 102i, 103e-h): 'The large size, prominent umbilical tubercles and wide ventral sulcus are all points of similarity with $D$. invernoisi (Coquand), which also occurs below the maximum development of $D$. mammillatum. Coquand's type specimen is an ammonite $135 \mathrm{~mm}$ in diameter [Pictet \& Renevier give the diameter as $160 \mathrm{~mm}$.] from Perte-du-Rhône (Ain), France, which Pictet \& Renevier $(1854$, p. 23, pl. ii, figs. 1a, 1b) ascribed to Ammonites mammillatus. If correctly figured, it differs from the present species in details of tuberculation, the tubercles being more persistent and differently spaced on the flank, though less vigorous on the venter and outer part of the sides in the young.' Casey also reproduced the figures of Pictet \& Renevier (his text-fig. 98 on p. 277), where he referred to it as the holotype. In introducing his new species, Coquand included reference to the description and figures of Pictet \& Renevier in his synonymy, and mentioned a specimen from Aptian marls in Aragon, Spain, and one from the 'bancs supérieurs de l'étage Aptien' of Arcaïne. He also records the species from Lancrans (Ain, France). The specimen figured by Pictet \& Renevier is thus a syntype. We have thus far failed to trace the figured syntype, said by Pictet \& Renevier to be in the Rochat Collection, or the $220 \mathrm{~mm}$ diameter syntype in the Mayor Collection. The third and largest syntype, $560 \mathrm{~mm}$ in diameter and from Lancrans, survives in the collections of the Musée Cantonal de Géologie, Lausanne, with the catalogue number MGL15704, Fig. 23. It is interpreted as a poorly preserved macroconch Douvilleiceras of the mammillatum group.

There is an uncatalogued specimen in the Matheron Collection (now in the Hungarian Natural History Museum, Budapest) labelled 'Ammonites invernoisi, Coq, Fondoille', the label is not, however, the original, and the specimen is a compressed and finely ribbed acanthoplitine, bearing no 
resemblance to Pictet \& Renevier's figures. We are also less certain than Casey on the age of their specimen. The succession at Perte-du-Rhône (now flooded) is described in detail by Jayet (1926), and discussed by Kennedy \& Delamette (1994). Urgonian limestones are overlain by a glauconitic terrigenous-clastic sequence that ranges from Upper Aptian to Upper Albian. Jayet records Douvilleiceras in association with Leymeriella in his bed 3 (p. 176), and in association with Leymeriella and Hoplites in his bed 36 (p. 17). Kennedy \& Delamette (1994) suggested that Jayet's bed 36 included remanié Leymeriella associated with ammonites spanning the upper Lower Albian Pseudosonneratia (Isohoplites) steinmanni Subzone to the Hoplites spathi Subzone of the lower Middle Albian. We are, accordingly, less certain than Casey that Pictet \& Renevier's specimen is from 'below the maximum development of $D$. mammilatum.' The figure shows an individual that appears to be an adult, though whether complete or not is unclear. There are weakening, but persistent relatively strong umbilical bullae, and at least five additional rows of tubercles on primary ribs, with one to three long or short intercalated ribs with at least four rows of tubercles between successive primaries. The affinities of the specimen, beyond belonging to the mammillatum group are, to us, uncertain.

Douvilleiceras spiniferum (Whiteaves, 1876) (p. 24, pl. 3, fig. 1; text-fig. 2), from the Haida Formation of the Queen Charlotte Islands of British Columbia was comprehensively revised by McLearn (1972, p. 62, pl. 10, fig. 1-3, pl. 11, figs 1, 2; pl. 28, fig. 10. The lectotype (ibid., pl. 11, fig. 1) appears to be an incomplete microconch. The tuberculation is described by McLearn as comprising six rows of tubercles, three rounded flank tubercles, and three rounded ventrolateral tubercles on one side, and seven on the other, as a result of the presence of an additional row in an inner ventrolateral position relative to the others. The lectotype of spiniferum thus differs from the neotype of $D$. mammillatum in the shape of the ventrolateral tubercles: rounded rather than clavate, and the fewer number of rows, three or four versus five in mammillatum. We note, however, that one of McLearn's specimens (1972, pl. 10, fig. 3) has clavate ventrolateral tubercles, as in mammillatum, but only three rows. A further difference is seen in the original of McLean's pl. 28, fig. 1, a phragmocone estimated to be $220 \mathrm{~mm}$ in diameter from the figure (said to be reduced 0.5), and showing loss of tuberculation, a feature generally characteristic of the adult body chamber in D.mammillatum. We exclude spiniferum from the synonymy of mammillatum on the basis of these characters.

Douvilleiceras offarcinatum (White, 1887) (p. 219, pl. 23, figs 3,4 ; the figures and description are reproduced in Maury (1936, p. 245 , pl. 23, figs 2,3 ) was based on a number of specimens from Sergipe, Brazil, of which two were figured; they are described as having ribs that are 'marked by numerous, more or less distinct, often obscure, nodes, which are arranged in four or five revolving rows on each side of the narrow peripheral depression before mentioned; the two rows which lie nearest the periphery being the most prominent.' White's pl. 23, fig. 3 shows the side view of an individual with a maximum preserved diameter of $61 \mathrm{~mm}$. On the adapical half of the outer whorl, the ribs are coarse and relatively distant, with both bullate primaries and long intercalatories, the former with weak umbilical bullae, stronger inner ventrolateral tubercles, and stronger outer ventrolaterals. The adapertural $120^{\circ}$ sector of the outer whorl has more regular ribbing, the ribs all primaries, with very weak umbilical bullae, weak inner ventrolateral bullae, and at least two rows of outer ventrolateral clavi. White's pl. 23, fig. 4 shows the ventral view of a specimen with a maximum preserved diameter of $76.5 \mathrm{~mm}$. At the adapical end, four rows of tubercles are visible on the ventrolateral shoulder of the first two ribs, reducing to two on the third, and then to one, that weakens towards the adapertural end. The specimens are interpreted as parts of small adults, presumably microconchs. They compare with specimens here assigned to D. mammillatum, White's fig. 3 resembling OUM K9932 (Fig. 15E, F), fig. 4 resembling OUM K9924A (Fig. 15A-C). More and better material is needed to determine the affinities of the species; Cooper (1982, p. 272) regarded the original of Maury's pl. 23, fig. 4 as a possible synonym of his D. mammillatum aequinodum

D. mammillatum paucicostatum (Parona \& Bonarelli, 1897) (p. 95(43), pl. 13 (4), fig. 4) is from the condensed Albian of Escragnolles, Alpes-Maritimes, France. It is very evolute, with strongly rursiradiate ribs, some convex across the ventrolateral shoulder, and is a pathological individual in our view, as is the original of Parona \& Bonarelli's pl. 13 (4), fig. 5.

The holotype, by monotypy, of Douvilleiceras aurarium Anderson, 1938 (p. 175, pl. 53, fig. 1), from Shasta County in Northern California, is a well-preserved individual retaining extensive areas of shell material, with a maximum preserved diameter of $83 \mathrm{~mm}$. It is illustrated in side view only, and has massive inner ventrolateral tubercles, on the penultimate whorl, not, apparently, developing an inner lateral tubercle. The ventrolateral tuberculation is unclear from the figure, although described by Anderson (1938, p. 175) when comparing it to D. mammillatum, as 'less numerous, more rounded, and on the ventrolateral borders, they are not always multiple'

Douvilleiceras restitutum Anderson, 1938 (p. 175, pl. 54, fig. 2) is based on a holotype $153 \mathrm{~mm}$ in diameter, and also from Shasta County. It is described as having three to five rows of rounded spinose tubercles on the early whorls, the umbilical persisting and strengthening. McLearn (1972, p. 66) thought it close to Douvilleiceras spinosum.

Scott (1940) described six species of Douvilleiceras from the Cuchillo Formation of Trans-Pecos Texas, all based on fragmentary, and generally crushed material. They were revised by Young (1974):

Douvilleiceras mammillatum (Schlotheim) emend. Spath; Scott, p. 1007, pl. 56, fig. 10; pl. 57, figs 3, 4. The original of Scott's pl. 56, fig. 10 was refigured by Young 1974, pl. 5, fig. 4 . The original of Scott's pl. 57, figs 3, 4, was refigured by Young, 1974, pl. 5, figs 1, 2, who referred them to Douvilleiceras spathi Scott, 1940.

Douvilleiceras cuchillense Scott, 1940, p. 1009, pl. 59, figs 3, 4. Holotype refigured by Young 1974, pl. 4, fig. 11, pl. 5 , fig. 12 , who regarded it as a synonym of $D$. spathi, giving the latter page priority.

Douvilleiceras offarcinatum (White)?; Scott, p. 1011, pl. 58, figs 4, 5. Scott's specimen refigured by Young 1974, pl. 5, fig. 6, who referred to it as Douvilleiceras cfr. offarcinatum. 
D. spathi Scott, 1940, p. 1012, pl. 58, fig. 3; pl. 60, fig. 6 . Holotype refigured by Young 1974, pl. 4, fig. 9; pl. pl. 5, fig. 3

D. quitmanense Scott, 1940, p. 1014; p. 61, figs 9, 10. Holotype refigured by Young 1974, pl. 4, fig. 4; pl. 5, fig. 7; text-fig. $3 \mathrm{~b}$, who referred to it as Douvilleiceras cfr. mammillatum.

Douvilleiceras n. sp. indet., Scott, 1940, p. 1015, pl. 57, fig. 2. Refigured by Young 1974, pl. 5, fig. 11, who referred to it as Douvilleiceras cfr. mammillatum.

Douvilleiceras [Cheloniceras] adkinsi (Scott, 1940), p. 1005, pl. 56, figs 8, 9. Referred to as Douvilleiceras sp. juv. indet. by Young 1974, p. 192.

Douvilleiceras [Trinitoceras] rex Scott, 1940, p. 1017, pl. 60, figs 1-3. Holotype refigured by Young, 1974, pl. 6, fig. 10 , pl. 7, fig. 1 text-figs 2 d, $3 \mathrm{a}$, i.

Douvilleiceras [Trinitoceras] reesidei Scott, 1940, p. 1019, pl. 57, figs 5, 6; pl. 58, figs 1, 2, 6, 7; pl. 59, fig. 5. The species was not revised by Young.

Most of the material is poor and fragmentary. We regard the following as belonging to the mammillatum group: D. mammillatum, D. cuchillense, D. offarcinatum?, $D$. quitmanense, $D$. n. sp. indet., and $D$. adkinsi, and some may be synonyms of $D$. mammillatum, but more and better material is needed for certain identification (W.J.K. visited one of the principal localities, Mayfield Canyon on the north bank of the Rio Grande in Hudspeth County, Texas, in 1973, and found only poor fragments).

Douvilleiceras [Trinitoceras] reesidei is problematic. The venter of the smaller syntype figured by Scott (1940, pl. 57, fig. 6 ; pl. 59, fig. 5) is a half whorl of a nucleus $67 \mathrm{~mm}$ in diameter, with widely separated primary ribs bearing small umbilical bullae, strong conical inner ventrolateral tubercles, and strong, outer ventrolateral tubercles, with two spiral grooves and 3 spiral ridges, and a wide ventral sulcus. The larger syntypes (Scott 1940, pl. 58, figs 1, 2, 6, 7) are described as having only faint tuberculation on the flank at approximately $200 \mathrm{~mm}$ in diameter, with all tuberculation lost in the largest, macroconch, syntype at a diameter of an estimated $400 \mathrm{~mm}$. the coarse ornament of the inner whorls, and the presence of up to four long and short intercalated ribs between successive primaries middle growth (Scott 1940, $\mathrm{pl} .58$, figs 1,2 ) distinguish the species from D. mammillatum.

D. spinosum Tavani, 1942 (p. 120 (34), pl. 13 (4) figs 1, 2; pl. 14 (5), figs 3, 4,9), from Bugda Acable, Somalia, is based on three specimens. It appears to be a strongly tuberculate variant of $D$. mammillatum with (replaced) shell material preserved, retaining the septate spines on the umbilical and inner ventrolateral tubercles.

D. cheloniceratiforme Tavani (1949, p. 110 (38), pl. 19 (8), fig. 6) is based on a single individual, also from Bugda Acable. Tavani does not give the dimensions; the figure shows a $180^{\circ}$ whorl sector, $126 \mathrm{~mm}$ in diameter, apparently body chamber, the umbilicus comprising an estimated $30-35 \%$ of the diameter, the whorl breadth to height ratio around 1.2 from his figure (fig. a below the plate explanation). It is clearly a macroconch Douvilleiceras, differing in no significant respects from macroconch $D$. mammillatum from northern KwaZulu-Natal (Fig. 6 herein), but in the absence of information on the inner whorls, cannot be assigned to the species with complete certainty.

D. variabile Tavani, 1949 (p. 109 (37), pl. 21 (10), figs 1, 2, is based on two examples, again from Bugda Acable. Tavani writes of it as 'appartineti di gruppo del Douvilleiceras inaequinodum'. The figures shows a macroconch phragmocone with extensive areas of (replaced) shell material. The maximum preserved diameter is $160 \mathrm{~mm}$, and the whorl breadth to height ratio 1.25 (based on fig. a below the plate explanation). The tuberculation of the adapical $240^{\circ}$ sector of the outer phragmocone whorl corresponds to that of KwaZulu specimens of comparable size (OUM KX9922: Fig. 14I), while that of the adapertural $120^{\circ}$ sector, on which ventrolateral and ventral tuberculation declines, matches that of phragmocone OUM KX12643 (Fig. 6), that we refer to $D$. mammillatum, of which we regard variabile a synonym. Cooper (1982, p. 278, figs 4g, 7e-f, 8c-d, 9g, 11c-d, 13a, 15e, 22a) referred four worn individuals from Dombe Grande, Angola, to $D$. variabile. His largest figured specimen is only $80 \mathrm{~mm}$ in diameter (Cooper 1982, fig. 8c), and is much smaller than the smallest growth stage recognizable on Tavani's figured specimen. The main criteria cited by Cooper as diagnostic were main ribs with a distinct umbilical tubercle, a pronounced mid-lateral tubercle [inner ventrolateral in our terminology], and bullate ventrolateral tubercles that weaken beyond $45 \mathrm{~mm}$ diameter, and are lost at about $60 \mathrm{~mm}$ diameter. At this stage a small tubercle appears between the umbilical and mid-lateral [inner ventrolateral in our terminology], and the ventral tubercles bear three notches, such that there are eight tubercles per rib. There is invariably one, and sometimes two intercalatories between successive long ribs that lack mid-lateral (= inner ventrolateral tubercles of our terminology]. Cooper noted that within his collection 'several individuals seem to combine the characters of $D$. variabile and $D$. mammillatum aequinodum.... This seems to suggest that $D$. variabile is merely another morphotype within a polytypic $D$. mammillatum. While this is the writer's belief, opposition to the gross 'lumping' that such synonymies involve from one of the referee's of this paper has led to the adoption of a somewhat more cautious approach. Douvilleiceras variabile is here maintained because the writer does not believe in sympatric subspecies.' The chief distinguishing feature of this Angolan material is the invariable presence of one, and sometimes two intercalated ribs between primaries, and the strong inner ventrolateral tubercles. Individuals referred to variabile constitute only $6.5 \%$ of the total number of specimens of $D$. mammillatum aequinodum and $D$. variabile in the collection. Individuals of this type occur as rarities in the present collection (OUM KX10010, 12379: Fig. 13C-D), and we incline to Cooper's view that these individuals fall within a variable $D$. mammillatum.

Douvilleiceras? muralense Stoyanow, 1949 (p. 130, pl. 26, figs 1,2 ) is a nomen dubium based on a badly weathered fragment of phragmocone from the base of the Mural Limestone in Mule Mountains of southeastern Arizona.

Douvilleiceras submammillatum Eristavi, 1955 (p. 151, pl. 7, fig. 1), from the Lower Cretaceous of Georgia, is based on an individual $170 \mathrm{~mm}$ in diameter according to the figure (reproduced $\times 0.5$ ) which shows the side view only of a crushed individual with predominantly primary ribs, and umbilical, inner and outer ventrolateral tubercles only visible. As Casey (1962, p. 271) notes, its generic position is uncertain from the figure. Douvilleiceras planum 
Eristavi,1955 (p. 152, pl. 7, fig. 2) was referred to Eodouvilleiceras by Kvantaliani \& Sharikadze in Topchisvili (2005, p. 387, pl. 96, fig. 1) and recorded from the Upper Aptian; thus ruling out its allocation to Douvilleiceras.

Two of the specimens assigned to Douvilleiceras mammillatum by Collignon (1963) are illustrated here as Figs $21 \mathrm{~A}-\mathrm{C}$ and 22A-B. The original of his pl. 283, fig. 1241 was figured considerably reduced at $70 \mathrm{~mm}$ in diameter, wheras the dimensions on p. 109 show it to be $90 \mathrm{~mm}$ in diameter. It is dated as Middle Albian, and is relatively evolute ( $\mathrm{U}=34 \%$ of the diameter) and has a relatively broad ventral sulcus (Fig. 21C). In this respect it resembles the Lower Albian Douvilleiceras monile of Collignon (1963, pl. 287, fig. 1247 (Fig. 21D, E). We are uncertain of the affinities of these specimens. The original of Collignon's pl. 283, fig. 1239 (Fig. 22A, B) has coarsely ribbed inner whorls, as in OUM KX9932 (Fig. 15E, F)

D. pseudinaequinodatum Collignon, 1963 p. 120, pl. 268, 1249 ) belongs to the inaequinodum group, and is discussed further below.

D. subleightonense Mirzoyev, 1967 (p. 64, pl. 8, figs 1-3; text-fig. 4) from the Douvilleiceras mammillatum Zone of the Gissar Range, Tadjikistan, is interpreted as a macroconch of a slender variant of the present species.

D. charshangense Mirzoyev, 1967 (p. 58, pl. 7, figs 1-5; text-figs 1-3), also from the Gissar range of Tadjikistan, belongs to the inaequinodum group, and is discussed further below.

D. perchoisense Destombes, 1979 (p. 72, pl. 4-4, fig. 2) is a typical Douvilleiceras mammillatum. It is from the upper Lower Albian of Aube, France.

D. inaequicostatum Chiriac, 1981 (p. 87, pl. 18, fig. 3; text-fig. 36) from the southern Dobrogea, Romania, is based on a short fragment of phragmocone with a whorl height of $50 \mathrm{~mm}$, and only six ribs preserved, one of which is a short intercalatory, bearing weak outer ventrolateral tubercles. It is a fragment of a macroconch, possibly D. mammillatum, but better regarded as a nomen dubium.

D. compressum Futakami, 2003 (p. 237, figs 1a, b, 2) is from the presumed Lower Albian of Hokkaido, Japan. The holotype, and only known specimen, consists of part of a poorly preserved penultimate whorl, a $120^{\circ}$ sector preserving one flank and less than half of the venter, and a further $240^{\circ}$ sector with only parts of the flank preserved. It has, on the best-preserved sector (in our terminology) weak umbilical and inner lateral bullae, stronger inner ventrolateral bullae and four 'pustuliform' ventrolateral tubercles. The author regarded the compressed whorl section as diagnostic, but the preservation of the specimen makes the determination of the whorl section uncertain in our view. The shape of the ventrolateral tubercles distinguishes the specimen from $D$. mammillatum, but we are otherwise uncertain of its affinities.

Douvilleiceras leightonense Casey, 1962 (p. 274, pl. 41, fig. 1 ; pl. 42 , fig. 3 ; text-figs $96,97,102 \mathrm{i}, 103 \mathrm{e}-\mathrm{h}$, was introduced for the earliest known species of the genus, and originally described from southern England. The holotype, BMNH C84735, is shown in Fig. 2. Casey (1962, p. 274) described the typical form as: 'Similar to D. mammillatum up to about $40 \mathrm{~mm}$ in diameter, after which distinguished by costae less elevated and not so steep sided, and above all median ventral sulcus very wide and shallow, the bordering tubercles sharp-tipped. From about $100 \mathrm{~mm}$ diameter, costae dominate over tubercles and ribbing increasingly dense, tending to unite in pairs at large flat umbilical spine bases. At about $130 \mathrm{~mm}$ in diameter ventral and lateral nodes disappear and extra ribs are intercalated in ones, two and threes among the primaries, fading out before reaching the umbilical margin. This type of sculpture persists to about $250 \mathrm{~mm}$ in diameter and then degenerates until only faint radial ridges are left on the lower two-thirds of flank. Suture with relatively slender-stemmed saddles compared with that of $D$. mammillatum.' The species is the presumed ancestor of D. mammillatum and macroconchs reach an enormous size; Casey figured a phragmocone, referred to as $c f$. leightonense, that is $440 \mathrm{~mm}$ in diameter, corresponding to an estimated diameter, with body chamber, of at least $650 \mathrm{~mm}$. When compared with the largest, presumed macroconch phragmocone in the KwaZulu material (Fig. 8), this is $195 \mathrm{~mm}$ in diameter, and has umbilical and inner flank ribbing on the outer whorl like that on the penultimate whorl of Casey's specimen. The holotype of leightonense (Fig. 2) appears to be a microconch of the species. It is incomplete, with an estimated original diameter of $120 \mathrm{~mm}$ approximately, lacking the inner whorls. There are 14 ribs on the adapical half whorl, predominantly bullate primaries, with well-developed umbilical bullae on most, a small conical inner lateral tubercle, larger conical inner ventrolateral tubercle, and four progressively strengthening clavi on the ventrolateral shoulder of the phragmocone, to give a total of seven rows of tubercles. The ventral sulcus is wide and shallow. The position of the last septum is unclear; perhaps $180^{\circ}$ of body chamber are preserved. On the body chamber, the tubercles weaken, the ribs weaken and crowd, the number of non-bullate primaries and long intercalated ribs increase progressively. BMNH C40341 (Fig. 1) is the original of Casey (1962, text-fig. 103g, h). It consists of a $160^{\circ}$ sector of phragmocone with a maximum preserved costal whorl height of $24.4 \mathrm{~mm}$. A total of 10 primary ribs are preserved. They are coarse, straight and prorsiradiate, with small umbilical bullae, larger inner ventrolateral bullae and three clavi on the ventrolateral shoulder, becoming progressively stronger towards the mid-venter. There is a single intercalated nontuberculate ventral/ventrolateral rib. There are thus a total of five tubercles on each rib at the end of the adult phragmocone, compared to seven in D. mammillatum at the same ontogenetic stage, while the ventral sulcus is very wide compared to that of the neotype of D. mammillatum (Fig. 3).

The holotype of Casey's Douvilleiceras leightonense var. pringeli (1962, p. 277 pl. 41, fig. 3; text-fig. 102j) was briefly diagnosed as 'A variety with inner whorls coarsely tuberculated as in $D$. orbignyi Hyatt, the lateral tubercle remaining conspicuous at the middle of the side until at least 75 mm. diameter.'

Douvilleiceras scabrosum Casey, 1962 (p. 278, pl. 40, figs 1-3; pl. 42, fig. 2; text-figs 102f, 103i) differs in no significant respects from $D$. mammilatum, of which it is a synonym.

Douvilleiceras pustulosum Casey, 1962 (p. 288, pl. 42, fig. 11; text-figs $102 \mathrm{~g}, 103 \mathrm{c}$, d) has a very wide, shallow ventral sulcus, and may be no more than a variant of D. leightonense. 


\section{Occurrence}

Douvilleiceras mammillatum, as here interpreted, ranges from the kitchini Subzone of the chalensis Zone of the Lower Albian to the lower Middle Albian lyelli Subzone of the dentatus Subzone in terms of the NW Europen sequence. The geographic distribution extends from southern England to France, Germany, Switzerland, Poland, Romania, Bulgaria, Kazakhstan, Turkmenistan, Iran, northwestern India, northern Pakistan, Tunisia, Angola, northern KwaZuluNatal, Madagascar, and possibly Peru.

\section{Douvilleiceras inaequinodum (Quenstedt, 1849)}

Figs 5, 11D-L, 12G, H, 13I, J, 22C, D

1841 Ammonites mammillaris Schlotheim; d'Orbigny, p. 249 (pars), pl. 73, figs 1-3 only.

1849 Ammonites monile inaequinodus Quenstedt, p. 138, pl. 10, fig. 1

1897 Douvilleiceras inaequinodum (Quenstedt); Parona \& Bonarelli, p. 95 (43), pl. 13 (4), fig. 6.

1903 Douvilleiceras orbignyi Hyatt, p. 110.

1923 Douvilleiceras aff. inaequinodum (Quenstedt); Spath, p. 70, pl. 5, fig. 4.

1923 Douvilleiceras mammillatum (Schlotheim) var. baylei Spath, p. 70, pl. 5, fig. 4.

1923 Douvilleiceras inaequinodum (Quenstedt); Spath, p. 73, pl. 4, fig. 5; pl. 5, fig. 6 (with additional synonymy).

?1937 Douvilleiceras cf. inaequinodum (Quenstedt); Scott, p. 35, pl. 6, figs 3, 4; text-fig. 1.

1930 Douvilleiceras mammillatum var. baylei Passendorfer, p. 652.

1942 Douvilleiceras benonae Besairie; Tavani, p. 120 (34), pl. 12 (3), fig. 11; pl. 14 (5), figs 1, 2.

1950 Douvilleiceras inaequinodum (Quenstedt); Collignon, p. 46 , text-fig. 2.

1962 Douvilleiceras orbignyi Hyatt; Casey, p. 279, pl. 40, figs 6-8; pl. 42, figs 12, 13; text-figs 99, 100, 102h (with additional synonymy).

1962 Douvilleiceras inaequinodum (Quenstedt); Casey, p. 282, text-fig. 95c

1962 Douvilleiceras alternans Casey, p. 282, pl. 42, fig. 1; text-figs 101, 102l (with additional synonymy).

1962 Douvilleiceras magnodosum Casey, p. 284, pl. 42, fig. 4; text-fig. 102k.

1963 Douvilleiceras aff. baylei Spath; Collignon, p. 118 pl. 287, fig. 1248.

1963 Douvilleiceras pseudinaequinodum Collignon, p. 120, pl. 388, fig. 1249

1965 Douvilleiceras orbignyi Hyatt; Howarth, p. 345, pl. 1, fig. 5.

?1967 Douvilleiceras charshangense Mirzoyev, p. 58, pl. 7, figs $1-5$; text-figs $1-3$.

1974 Douvilleiceras sp. cf. C. orbignyi Hyatt; Young, p. 188 pl. 5, figs 9, 10.

1979 Douvilleiceras orbignyi Hyatt; Destombes, p. 71, pl. 4-5, fig. 1; pl. 4-6, fig. 1 .

1979 Douvilleiceras alternans Casey; Destombes, p. 72

1979 Douvilleiceras inaequinodum (Quenstedt); Destombes, p. 72 , pl. 4.6, fig. 2.

1980 Douvillleiceras mammillatum (Schloth.); Krishna, pl. 1, figs 2, 7 (non p. 51).

?1980 Douvilleiceras inaequinodum Quenstedt; Krishna, p. 51, non pl. 2, figs 2, 4.
1982

Douvilleiceras inaequinodum (Quenstedt, 1849); Cooper, p. 281, text-figs 4c,d, f; 6a; 7a-c; 9d, f, h; 10e; 11a; 12c, d, g, h.

1988 Douvilleiceras alternans Casey; Owen, p. 211.

1988 Douvilleiceras magnodosum Casey; Owen, p. 212.

1990 Douvilleiceras orbignyi Hyatt; Marcinowski \& Wiedmann, p. 52.

1997 Douvilleiceras orbignyi Hyatt, 1903; Kennedy in Kennedy, Bilotte \& Hansotte, p. 469, pl. 6, figs 20, 21.

2003 Douvilleiceras kawashitai Futakami, p. 240, figs 3a-e.

2008 Douvilleiceras alternans Casey, 1962; Latil, p. 258, pl. 2, figs 1-3.

2010 Douvilleiceras gr. orbignyi Hyatt, 1903; Matrion in Colleté, p. 182, text-fig. 128A-D.

2011 Douvilleiceras magnodosum Casey, 1962; Latil, p. 370, pl. 9, figs 10-13.

2013 Douvilleiceras alternans Casey, 1962; Klein \& Bogdanova, p. 59 (with additional synonymy).

2013 Douvilleiceras inaequinodum (Quenstedt, 1846); Klein \& Bogdanova, p. 61 (with additional synonymy).

2013 Douvilleiceras magnodosum Casey, 1962; Klein \& Bogdanova, p. 62 (with additional synonymy).

2013 Douvilleiceras orbignyi Hyatt, 1903; Klein \& Bogdanova, p. 70 (with additional synonymy).

2013 Douvilleiceras pseudinaequinodum Collignon, 1963; Klein \& Bogdanova, p. 71.

2014 Douvilleiceras inaequinodum (Quenstedt, 1849); Amédro, Matrion, Magniez-Jannin \& Touch, pl. 10, fig. 5 .

Type

The holotype is the original of Quenstedt 1849, pl. 10, fig. $1 \mathrm{a}$, from the environs of Nice. The figure is reproduced by Spath (1925, text-fig. 15a on p. 74) and Casey (1962, text-fig. $95 \mathrm{c}$ on p. 9273)

\section{Material}

OUM KX4853, 4858, 4863, 4864, 4867, 4869, 4870, 4871, 4876 , and 4877 , from locality 53. OUM KX5808, from locality 142. OUM KX9949, from locality 175. OUM KX1006, from locality 176. OUM KX9891 from southwest of Ndumu.

\section{Description}

The best-preserved specimen, OUM KX4863 (Fig. 11F, G) is a phragmocone $63 \mathrm{~mm}$ in diameter, retaining recrystallized shell. Coiling is involute, the umbilical wall notched to accommodate the inner ventrolateral spines of the preceding whorl. The umbilicus is deep, and comprises $31 \%$ of the diameter, the umbilical wall feebly convex, the umbilical shoulder broadly rounded. The whorl section is depressed reniform in intercostal section, with a whorl breadth to height ratio of 1.44 , the greatest breadth just below mid-flank. The penultimate whorl lacks an umbilical bulla on the adapical part. The inner ventrolateral tubercles bear long, septate spines. There are sixteen primary ribs on the outer whorl. They arise at the umbilical seam, and strengthen across the umbilical wall, developing into small umbilical bullae that strengthen progressively as size increases. A single broad, feebly prorsiradiate, progressively strengthening rib connects to a much stronger conical inner ventrolateral tubercle, the base of a septate spine. A low broad rib 
connects to a massive outer ventrolateral tubercle, asymmetrically conical, and divided into three spirally elongated ridges by two grooves. The ridges become progressively stronger towards the mid-ventral region. A low, broad, transverse rib connects the tubercles across the venter, which is deeply concave in costal section. On the adapical half of the outer whorl, the ventral part of the rib is divided into an adapertural and adapical riblet by a median groove. A single intercalated rib is present on the ventrolateral shoulders and venter between the second and third, and third and fourth ribs from the adapertural end of the outer whorl.

The septate spines are particularly well preserved on OUM KX4864 (Fig. 11E). OUM KX5808 (Fig. 11D, H) has even more prominent outer ventrolateral tubercles, here divided into four spiral ridges by three spiral grooves; there are no intercalated ribs in this specimen. OUM KX4858 (Fig. 11I, J) is is interpreted as an adult microconch, with a $120^{\circ}$ sector of body chamber, and a maximum preserved diameter of $78 \mathrm{~mm}$. On the phragmocone, the outer ventrolateral tubercles are divided into four spiral ridges, and there is a single weak riblet intercalated between successive primaries. On the body chamber, the outer ventrolateral tubercles rapidly weaken, as do the umbilical bullae, leading to an ornament of alternating primary and intercalated ribs of only slightly different strengths, the primaries notched by three spiral grooves on the ventrolateral shoulder, producing four spiral ridges that strengthen progressively towards the mid-venter. OUM KX4876 (Fig. 12G, H), a worn fragment with a maximum preserved intercostal whorl height of $29 \mathrm{~mm}$, has single well-developed intercalated ribs between successive primaries, one of them strengthened into feeble outer ventrolateral tubercles.

OUM KX10006 (Fig. 13I, J) is interpreted as an incomplete macroconch, $99 \mathrm{~mm}$ in diameter, with a $90^{\circ}$ sector of body chamber. The cross section of the penultimate whorl reveals a deep ventral sulcus between outer ventrolateral bullae. On the phragmocone, the primary ribs bear small umbilical, and larger inner ventrolateral bullae, the bases of septate spines, partially preserved in places, together with small inner ventrolateral tubercles. Strong outer ventrolateral bullae (albeit weaker than on the outer whorl), are divided by three grooves into a smaller, rounded inner tubercle and three strong spiral ridges; the ventral sulcus is broad and of moderate depth, and crossed by a low, broad rib, in some cases differentiated into a pair of riblets. There are seven rows of tubercles on each rib. One or two intercalated ribs separate successive primaries. They may lack tubercles, or bear feeble outer ventrolateral bullae. The strong outer ventrolateral bulla on the primary ribs declines abruptly on the body chamber, leaving three rows of feeble tubercles.

\section{Discussion}

The figure of the holotype is a ventral view showing three strongly tuberculate ribs, the outer ventrolateral tubercles divided into four spiral ridges by three grooves, separated by two intercalated nontuberculate ribs. A single suture is indicated. Casey (1962, p. 281) separated Douvilleiceras inaequinodum (which he regarded as a typically Middle Albian species) from $D$. orbignyi (the neotype, designated by Casey, 1962, p. 279, is the original of Bayle, 1878, pl. 60, fig. 4, from the condensed Albian of Machéroménil, Ardennnes, France, in the Collections of the École des Mines, now housed in the Université Claude Bernard, Lyon, and illustrated here as Fig. 5) on the basis of the presence of two rather than a single intercalated rib between successive strongly tuberculate ribs in inaequinodum. As Cooper (1982, p. 284) has noted, some lower Middle Albian Douvilleiceras that he referred to inaequinodum have a single intercalated rib (1982, fig. 12C, D, G, H). Destombes (1979, pl. 6-4, figs 1, 2) illustrated (as D. orbignyi and D. inaequinodum) co-occurring individuals with one, two or three intercalated ribs, and Matrion (in Colleté 2010, fig. 128a-d) specimens he referred to as Douvilleiceras gr. orbignyi with single intercalated ribs and pairs of intercalated ribs. The number of intercalated ribs is regarded as a no more than intraspecific variation here, and we follow Cooper (1962) in drawing the species limits more widely than did Casey. The change on the adapical part of the adult body chamber from the hypernodose pre-adult stage to the predominantly ribbed adult stage with progressively weakening tubercles is striking, and much more pronounced than the same event in D. mammillatum. OUM KX4858 (Fig. 11I, J) is interpreted as an adult microconch, lacking most of the adult body chamber. The adult macroconch phragmocone is represented by the neotype of Douvilleiceras orbignyi Hyatt, 1903 (Text-fig. 5), and a specimen from Ford Place, Wrotham, Kent (Casey 1962, text-fig. 100 on p. 281), $150 \mathrm{~mm}$ in diameter, whilst OUM KX10006 (Fig. 13I, J) is interpreted as a smaller macroconch that preserves the change from phragmocone to body chamber. The holotype of Douvilleiceras benonae Besairie, 1936 (p. 164, pl. 15, figs 15, 16) was figured at half natural size. We have not seen the specimen, which appears to be an adult body chamber, with massive outer ventrolateral horns on primary ribs, separated by a single nontuberculate rib at the adapical end, thereafter increasing to five. This increase appears to be a character of adult body chambers of the hypernodose Douvilleiceras, but the high number seen in benonae is distinctive. Collignon (1963, pl. 284, fig. 1244) figured a smaller fragment with six intercalated ribs between successive hypernodose primaries. Typical inaequinodum are, however, present in the Madagascan fauna: the original of Douvilleiceras aff. baylei Spath of Collignon (1963, pl. 287, fig. 1248: Fig. 22C, D).

Douvilleiceras benonae Besairie of Tavani (1942, p. 120 (34), pl. 12 (3), fig. 11; pl. 14 (5), figs 1, 2, figs 1, 2) appears to be a crushed example of the present species.

The specimen of Douvilleiceras alternans from Machéroménil figured by Casey (1962, text-fig. 101 on p. 283) is an adult macroconch, showing the same ontogenetic changes in ornament on the body chamber as the incomplete microconch OUM KX4858 (Fig. 11I, J). Casey (1962, p. 282) noted that there were many transitions between $D$. orbignyi and $D$. alternans, and the differences he cites fall within intraspecific variation in our view.

Douvilleiceras magnodosum Casey, 1962 (p. 284, pl. 42, fig. 4; text-fig. 102) was based on two specimens only. The holotype, a $60^{\circ}$ whorl sector was separated from $D$. alternans on the basis of a more depressed whorl section, unusually high position of the lateral tubercle on the flank, and in possessing two intermediary ribs between successive pairs of greatly exaggerated ventral tubercles at an earlier 
stage of growth stage. We regard this fragment as no more than an intraspecific variant of $D$. inaequinodum.

Douvilleiceras pseudinaequinodum Collignon, 1963 (p. 120, pl. 388, fig. 1249) is based on an individual $185 \mathrm{~mm}$ in diameter from the 'Albien Moyen' of Ambarimaninga (Mitsinjo-Namakia), Madagascar. Collignon described the ornament on the adapical part of the outer whorl as corresponding to that of $D$. inaequinodum, from which he differentiated it on the weakening of the larger tubercles on the adapertural part of the outer whorl. It is interpreted here as a macroconch $D$. inaequinodum.

Douvilleiceras charshangense Mirzoev, 1967 (p. 58, pl. 7, figs 1-5; text-figs 1-3) from the southern slopes of the Gissar Range in Tadjikistan, has a nucleus to a diameter of $55 \mathrm{~mm}$ that is close to the holotype of Douvilleiceras mammillatum var. baylei Spath, 1923 (p. 70), figured by Casey (1962, text-fig. 99b, c, on p. 280) as Douvilleiceras orbignyi. At larger diameters, the ornament weakens; it may be no more than a variant of $D$. inaequinodum.

The holotype of Douvilleiceras kawashitai Futakami, 2003 (p. 240, figs 3a-e, 4a) is very close to OUM KX4863 (Fig. $11 \mathrm{G}, \mathrm{H}$ ), and we regard it as a further synonym of D. inaequinodum.

\section{Occurrence}

As here interpreted, Douvilleiceras inaequinodum ranges from Upper Lower to lower Middle Albian. The geographic distribution extends from southern England to France, Poland, Tunisia, Angola, northern KwaZulu-Natal, Madagascar, northwest India (Rajastan), Japan, and Texas (?).

\section{ACKNOWLEDGEMENTS}

Kennedy acknowledges the support of the staff of the Geological Collections, Oxford University Museum of Natural History, and the Department of Earth Sciences, Oxford, and the financial assistance of the Oppenheimer Fund (Oxford). Klinger acknowledges support of the staff of the Natural History Collections Department of Iziko, South African Museum, and financial support from the NRF, South Africa. We thank Robin Marchand of the Musée Cantonal de Géologie de Lausanne for assistance in locating the surviving type material of Douvilleiceras invernoisi, and Stefan Ansermet for providing the originals of Fig. 23. The originals of Figs 1-3 were provided by P. Hurst of the photographic unit of the Natural History Museum, London. We thank F. Amédro for reviewing the manuscript.

\section{REFERENCES}

AMÉDRO, F. 1992. L'Albien du bassin anglo-parisien: ammonites, zonation phylétique, sequences. Bulletin des Centres de Recherche, Exploration - Production Elf-Aquitaine 16: 187-223.

AMÉDRO, F., MATRION, B., MAGNIEZ-JANNIN, F. \& TOUCH, R. 2014. La limite Albien inférieur-Albien moyen dans l'Albien type de l'Aube (France): ammonites, foraminifères, séquences. Revue de Paléobiologie, Genève 33: 159-279.

ANDERSON, F.M. 1938. Lower Cretaceous deposits in California and Oregon. Geological Society of America Memoir 16: x + 1-339.

BAYLE, É. 1878. Fossiles principaux des terrains. Explication de la Carte Géologique détaillé le France 4, (1), (Atlas), 158 pls. Paris: Service de la Carte Géologique.

BESAIRIE, H. 1936. Recherches géologiques à Madagascar. Première Suite:, la géologie du Nord-Ouest. Mémoire de l'Academie Malgache: xii + 1-259.
BREISTROFFER, M. 1947. Sur les zones d'ammonites dans l'Albien de France et d'Angleterre. Travaux du Laboratoire de Géologie de la Faculté des Sciences de l'Université de Grenoble 26: 17-104 (1-88 in separates).

CASEY, R. 1961. A monograph of the Ammonoidea of the Lower Greensand. Part 3. Palaeontographical Society Monograph: 119-216.

CASEY, R. 1962. A monograph of the Ammonoidea of the Lower Greensand. Part 4. Palaeontographical Society Monograph: 217-288.

CHIRIAC, M. 1981. Amoniti Cretacici din Dobrogia de Sud. Studiu biostratigraphic. 1-143. Bucarest: Editura Academiae Republicii Socialiste România. 143 pp.

COLLETÉ, C. 2010 (coordinateur). Stratotype Albien. 1-330. Paris: Muséum National d'Histoire Naturelle; Orleans: Biotope Mèze; BRGM.

COLLIGNON, M. 1949. Recherches sur les faunes albiennes de Madagascar I. L'Albien d'Ambarimaninga. Annales Géologiques du Service des Mines, Madagascar 14: 1-128.

COLLIGNON, M. 1950. Recherches sur les faunes albiennes de Madagascar 3. L'Albien de Komihevitra Annales Géologiques du Service des Mines, Madagascar 17: 21-54.

COLLIGNON, M. 1963. Atlas des fossiles caracteristiques de Madagascar (Ammonites). X. Albien. xv + 1-184. Tananarive: Service Géologique.

COOPER, M.R. 1982. Lower Cretaceous (Middle Albian) ammonites from Dombe Grande, Angola. Annals of the South African Museum 89: 265-314.

COQUAND, H. 1865-1866. Monographie de l'étage Aptien de l'Espagne. 1-121. Marseille: Arnaud \& Cie.

DESTOMBES, P. 1979. Les Ammonites de l'Albien inférieur et moyen dans le stratotype de l'Albien: Gisements, paleontologie, biozonation. 51-19. In RAT, P.et. al., Les Stratotypes Francais, 5, L'Albien de l'Aube. 1-448. Paris: Edition du CNRS.

ERISTAVI, M.S. 1955. [Fauna of the Lower Cretaceous of Georgia.] Akademia Nauk Gruzinskoi Monograph 6: 1-225. [In Russian]

ETAYO-SERNA, F. 1979. Zonation of the Cretaceous of central Colombia by Ammonites. Publicaciones Géologicos Especiales del Ingeominas, Bogota 2: 1-186.

ETHERIDGE, R. 1907. Cretaceous fossils of Natal. II. The Umsinene River Deposit. Report of the Geological Survey of Natal and Zululand 3: 67-90.

FORBES, E. 1846. Report on the Fossil Invertebrata from southern India, collected by Mr. Kaye and Mr. Cunliffe. Transactions of the Geological Society of London (2), 7: 97-174.

FUTAKAMI, M. 2003. New species of Douvilleiceras (ammonoid) from the Lower Cretaceous Yezo Group in Hokkaido. Proceedings of the Japan Academy B79: 237-241.

GROSSOUVRE, A. de 1894. Recherches sur la craie supérieure, 2, Paléontologie. Les ammonites de la craie supérieure. Mémoires du Service de la Carte Géologique détaillée de la France, 1-264.

GAUTHIER, H. 2006. Révision Critique de la Paléontologie Française d'Alcide d'Orbigny, 6, Céphalopodes Crétacés. 1-292 +1-662. Leiden: Bakhuys.

HOWARTH, M.K. 1965. Cretaceous ammonites and nautiloids from Angola. Bulletin of the British Museum (Natural History) Geology 10: 335-412.

HYATT, A 1903. Pseudoceratites of the Cretaceous. United States Geological Survey Monograph 44: 1-351.

IMMEL, H., SEYED-EMAMI, K. \& AFSHAR-HARB, A. 1997. Kreide-Ammoniten aus dem iranischen Teil des Koppeh-Dagh (NE-Iran). Zitteliana 21: 159-170.

JACOB, C. 1905. Étude sur les ammonites et sur l'horizon du gisement de Clansayes. Bulletin de la Société Géologique de France (4), 5: 339-342.

JACOB, C. \& TOBLER, A. 1906. Étude stratigraphique et paléontologique du gault de la Vallée de la Engelberger. Mémoires de la Société Paléontologique Suisse 33: 3-26.

JAYET, E. 1926. Étude stratigraphique de la Perte-du-Rhone, près de Bellegarde (Ain). Eclogae Geologicae Helvetiae 20: 159-222.

KENNEDY, W. J. 1986. Observations on Astiericeras astierianum 
(d'Orbigny, 1842) (Cretaceous Ammonoidea). Geological Magazine 123: 507-513.

KENNEDY, W. J., BILOTTE, M. \& HANSOTTE, M. 1997. Albian ammonite faunas from Pech de Foix (Ariège, France). Bulletin des Centres de Recherche Exploration - Production Elf-Aquitaine 21: 457-499.

KENNEDY, W.J. \& DELAMETTE, M. 1994. Neophlycticeras Spath, 1922 (Ammonoidea) from the Upper Albian of Ain, France. Neues Jahrbuch für Geologie und Paläontologie Monatshefte 191: 1-24.

KENNEDY, W.J. \& FATMI, A.N. 2014. Albian ammonites from northern Pakistan. Acta Geologica Polonica 64: 47-98.

KENNEDY, W.J. \& KLINGER, H.C. 1975. Cretaceous faunas from Zululand and Natal, South Africa. Introduction, Stratigraphy. Bulletin of the British Museum (Natural History) Geology 25: 263-315.

KENNEDY, W.J. \& KLINGER, H.C. 1978. Cretaceous faunas from Zululand and Natal, South Africa. A new genus and species of Gastroplitinae from the Mzinene Formation (Albian). Annals of the South African Museum 77: 57-69.

KENNEDY, W.J. \& KLINGER, H.C. 2008. Cretaceous faunas from Zululand and Natal, South Africa: The ammonite subfamily Lyelliceratinae Spath, 1921. African Natural History 4: 57-111.

KENNEDY, W.J. \& KLINGER, H.C. 2009. The heteromorph ammonite Ndumuiceras variabile gen. et sp. nov., from the Albian Mzinene Formation, KwaZulu-Natal, South Africa. African Natural History 5: 43-47.

KENNEDY, W J., WRIGHT, C W. \& KLINGER, H C. 1979. Cretaceous faunas from Zululand and Natal, South Africa. A new genus and species of tuberculate desmoceratacean from the Mzinene Formation (Albian). Annals of the South African Museum 78: 29-38.

KLEIN, J. \& BOGDANOVA, T. 2013. Lower Cretaceous ammonites VI Douvilleiceratoidea \& Deshayesitoidea. Fossillium Catalogus 1: Animalia 151 (pars): 1-299.

KLINGER. H.C. \& KENNEDY, W.J. 2008. Mkuzeiella andersoni gen. et sp. nov. (Cephalopoda, Ammonoidea) from the Albian Mzinene Formation of KwaZulu-Natal, South Africa. Bulletin de l'Institut royal des Sciences naturelles de Belgique, Sciences de la Terre 78: 179-191.

KLINGER, H.C., WIEDMANN, J. \& KENNEDY, W.J. 1975. A new carinate phylloceratid ammonite from the early Albian (Cretaceous) of Zululand, South Africa. Palaeontology 18: 657-664.

KORN, D., EBBIGHAUSEN, V., BOCKWINKEL J. \& KLUG, C. 2003. The A-mode ontogeny in prolecanitid ammonites. Palaeontology 46: 1123-1132.

KRISHNA, J. 1980. Uncoiled ammonites of Middle Albian (Lower Cretaceous) age from Habur Series, Jaisalmer, Rajasthan. Journal of the Paleontological Socity of India 23/24: 49-54.

KULLMANN, J. \& WIEDMANN, J. 1970. Significance of sutures in phylogeny of Ammonoidea. University of Kansas, Paleontological Contributions 42: 1-32.

LAPPARENT, A. DE \& FRITEL, P. 1888. Fossiles caractéristiques des terrains sédimentaires. 2. Fossiles secondaires. 20 pls. Paris: F. Savy.

LATIL, J.L. 2008. A revision of Amaltheus ebrayei De Loriol, 1882, type species of the genus Parengonoceras Spath, 1924. Revue de Paléobiologie 27: 249-264.

LATIL, J.L. 2011. Early Albian ammonites from Central Tunisia and adjacent areas. Révue de Paléobiologie 30: 321-429.

MARCINOWSKI, R. \& WIEDMANN, J. 1990. The Albian ammonites of Poland. Palaeontologica Polonica 50: 1-94.

MAURY, C.J. 1936. O Cretáceo de Sergipe. Monographias do Serviço Geologico e Mineralogico do Brasil 11: 1-283.

McLEARN, F.H. 1972. Ammonoids of the Lower Cretaceous Sandstone Member of the Haida Formation, Skidegate Inlet, Queen Charlotte Islands, western British Columbia. Geological Survey of Canada Bulletin 188: 1-78.

MICHELIN, H. 1838. Note sur une argile dépendant du Gault, observée au Gaty, commune de Gérodôd, département de l'Aube. Mémoires de la Société Géologique de France (1) 3: 97-103.

MIRZOYEV, G.G. 1967. [New species of Douvilleiceras from lower Albian deposits of the southwestern spurs of the Gissar range.]
Paleontologicheskii Zhurnal 1967: 57-67. [In Russian] (English translation: Paleontological Journal 1967: 53-63)

OBATA, I. 1969. Lower Cretaceous ammonites of the Miyako Group, part 3. Some douvilleiceratids from the Miyako Group. Transactions and Proceedings of the Palaeontological Society of Japan, New Series 76: 165-176.

ORBIGNY, A. d'. 1840-1842. Paléontologie française: Terrains crétacés. 1. Céphalopodes. 1-120 (1840); 121-430 (1841); 431-662 (1842). Paris: Masson.

ORBIGNY, A. d' 1853. Notes sur quelques coquilles fossiles recuilles dans les montagnes de la Nouvelle-Grenade, par M. Le général Joaquin Acosta. Journal de Conchyliologie 4: 208-214.

OWEN, H.G. 1988. The ammonite zonal sequence and ammonite taxonomy in the Douvilleiceras mammillatum Superzone (Lower Albian). Bulletin of the British Museum (Natural History) Geology 44: 177-231.

PARONA, C.F. \& BONARELLI, G. 1897. Fossili Albiani d'Escragnolles, del Nizzardo e della Liguria occidentale. Palaeontographica Italica 2: 53 (1)-107 (55).

PASSENDORFER, E. 1930. Studjum stratygraficzne i paleontologiczne i paleontologiczne nad Kreda serji wierchowej w Tatrach. [étude stratigraphique et paléontologique du Crétacé de la série hauttatrique dans les Tatras.] Prace Polskiego Instytutu Geologicznego 2 (for 1929): 439-677.

PICTET, F.J. \& RENEVIER, E. 1854-1858. Description des fossiles du terrain Aptien de la Perte-du-Rhône et des environs de Ste Croix. Matériaux pour la Paléontologie Suisse 1: 1-184.

QUENSTEDT, F.A. 1845-1849. Petrefactenkunde Deutschlands. 1, Cephalopoden. i, 1-104 (1845); ii, 105-184 (1846); iii, 185-264 (1847); iv, v, 265-472 (1848); vi, 473-580 (1849), 36 pls. Tübingen: H. Laupp.

RIEDEL, L. 1938. Amonitas del cretácico inferior de la Cordillera Oriental. Estudios geológicos y paleontólogicos sobre la Cordillera Orientale de Colombia, 2. Departamento Minas y Petróleos, Ministerio de Industria y Trabajo de la Republica Colombia: 7-80.

ROBERT, E. 2002. La transgression Albienne dans le Bassin Andin (Pérou: Biostratigraphie, Paléontologie (Ammonites) et Stratigraphie Séquentielle. Strata 38: 1-380.

SCHLOTHEIM, E.F. VON 1813. Beiträge zur Naturgeschichte der Versteinerungen in geognostischer Hinsicht. In: LEONHARD, C.C. Leonard's Taschenbuch für die gesammte Mineralogie, mit Hinsicht auf die neusten Entdeckungen 7: 3-134. Frankfurt am Main: Hermannsch Buchhandlung.

SCOTT, G. 1937. Ammonites of the genera Sonneratia and Douvilleiceras from the Cretaceous of Colombia. Journal of Paleontology 2: 34-37.

SCOTT, G. 1940. Cephalopods from the Cretaceous Trinity Group of the south central United States. University of Texas Publication 3945: 969-1106.

SOWERBY, J. 1812-1822. The Mineral Conchology of Great Britain. 1, pls. 1-9 (1812), pls. 10-44 (1813), pls. 45-78 (1814), pls. 79-102 (1815); 2, pls. 103-14 (1815), pls. 115-50 (1816), pls. 151-86 (1817), pls. 187-203 (1818); 3, pls. 204-21 (1818), pls. 222-53 (1819), pls. 254-71 (1820), pls. 272-306 (1821); 4, pls. 307-18 (1821), pls. 319-83 (1822). London: the author.

SPATH, L.F. 1922. On Cretaceous Ammonoidea from Angola, collected by Professor J.W. Gregory, D.Sc., F.R.S. Transactions of the Royal Society of South Africa 53: 91-160.

SPATH, L.F. 1923. A. monograph of the Ammonoidea of the Gault. Part 1. Palaeontographical Society Monographs: 1-72.

SPATH, L.F. 1925. A. monograph of the Ammonoidea of the Gault. Part 2. Palaeontographical Society Monographs: 73-110.

STOLICZKA, F. 1863-1866. The fossil cephalopoda of the Cretaceous rocks of southern India. Ammonitidae with revision of the Nautilidae etc. Memoirs of the Geological Survey of India. (1), Palaeontologica Indica 3: (1), 41-56(1863); (2-5), 57-106(1864); (6-9), 107-154(1865); (10-13), 155-216(1866).

STOYANOW, A. 1949. Lower Cretaceous stratigraphy in southeastern Arizona. Geological Society of America Memoir 38: vii + 169 pp. 
SZIVES, O. 2007. Aptian-Campanian ammonites of Hungary. Geologica Hungarica, Series Palaeontologica 57: 187.

TAVANI, G. 1942. Paleontologia della Somalia. III. Fossili del Cretaceo. 6. Molluschi del Cretaceo della Somalia. Palaeontographia Italica 32: 94 (7)-133 (47).

TAVANI, G. 1949. Fauna malacologica Cretacea della Somalia e dell'Ogaden. Parte seconda, Gastropoda-Cephalopoda-conclusioni. Palaeontographia Italica 45: 70 (1)-148 (76).

TOPCHISVILI, M.V. Atlas of Early Cretaceous fauna of Georgia. Georgian Academy of Sciences. A Janelidze Geological Institute. Proceedings. New Series 120: 1-445, $104 \mathrm{pls}$.

WEIDICH, K. F., SCHWERD, K. \& IMMMEL, H. 1983. Das helvetikum-Profil im Steinbruch "An der Schanz" bei Burgberg/Allgäu, Lithologie, Stratigraphie und Makrofauna. Zitteliana 10: 555-573.

WHITE, C.A. 1887. Contribution to the paleontology of Brazil; comprising descriptions of Cretaceous invertebrate fossils mainly of the provinces of Sergipe, Pernambuco, Para and Bahia. Archivos do Museu Nacional do Rio de Janeiro 7: $1-273$.
WHITEAVES, J.F. 1876. On some invertebrates from the coalbearing rocks of the Queen Charlotte Islands. Geological Survey of Canada, Mesozoic fossils 1: 1-92.

WIEDMANN, J. 1966. Stammesgeschichte und System der posttriadischen Ammonoideen; ein Überblick. Neues Jahrbuch für Geologie und Paläontologie Abhandlungen, 125: 49-79; 127, 13-81.

WRIGHT, C.W. 1957. [Cretaceous Ammonoidea]. In: MOORE, R.C. (ed.) Treatise on Invertebrate Paleontology. Part L, Mollusca 4, Cephalopoda Ammonoidea. xxii + 1-490 pp., New York and Lawrence: Geological Society of America and University of Kansas Press.

WRIGHT, C.W. 1996. Treatise on Invertebrate Paleontology. Part L, Mollusca 4: Cretaceous Ammonoidea. xx + 1-362 (with contributions by J.H. Calloman [sic] and M.K. Howarth). Lawrence, Kansas and Boulder, Colorado: Geological Society of America and University of Kansas.

YOUNG, K. 1974. Lower Albian and Aptian (Cretaceous) ammonites in Texas. Geoscience and Man 8: 175-228. 

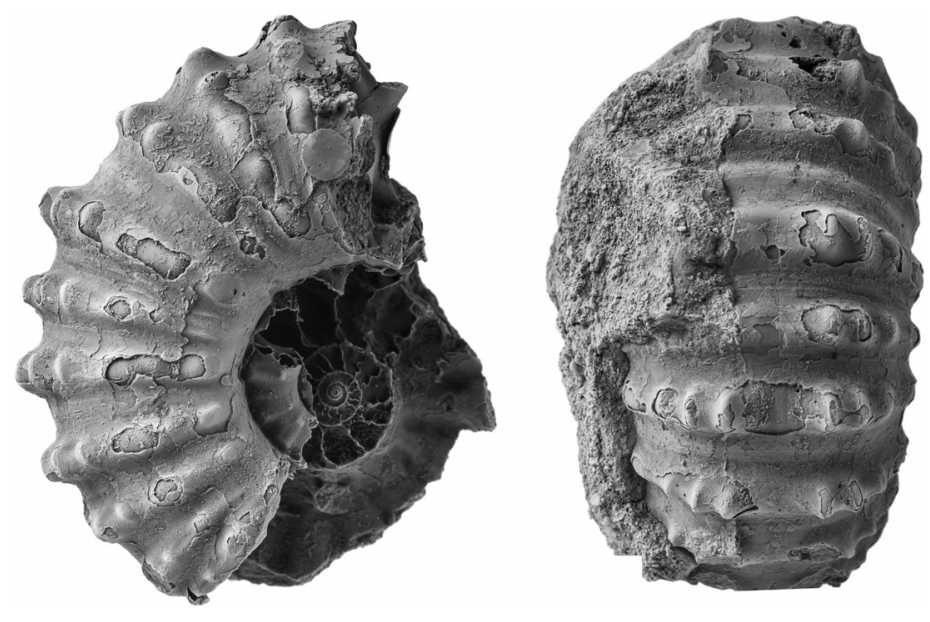

Fig. 1. Douvilleiceras leightonense Casey, 1962. BNMH C40341, the original of Casey 1962, text-fig. 103g, h, from the condensed Lower Albian regularis-mammillatum nodule bed of Arnold's Pit, Billington Crossing, Leighton Buzzard, Bedfordshire, England. Figures are $\times 1$. 


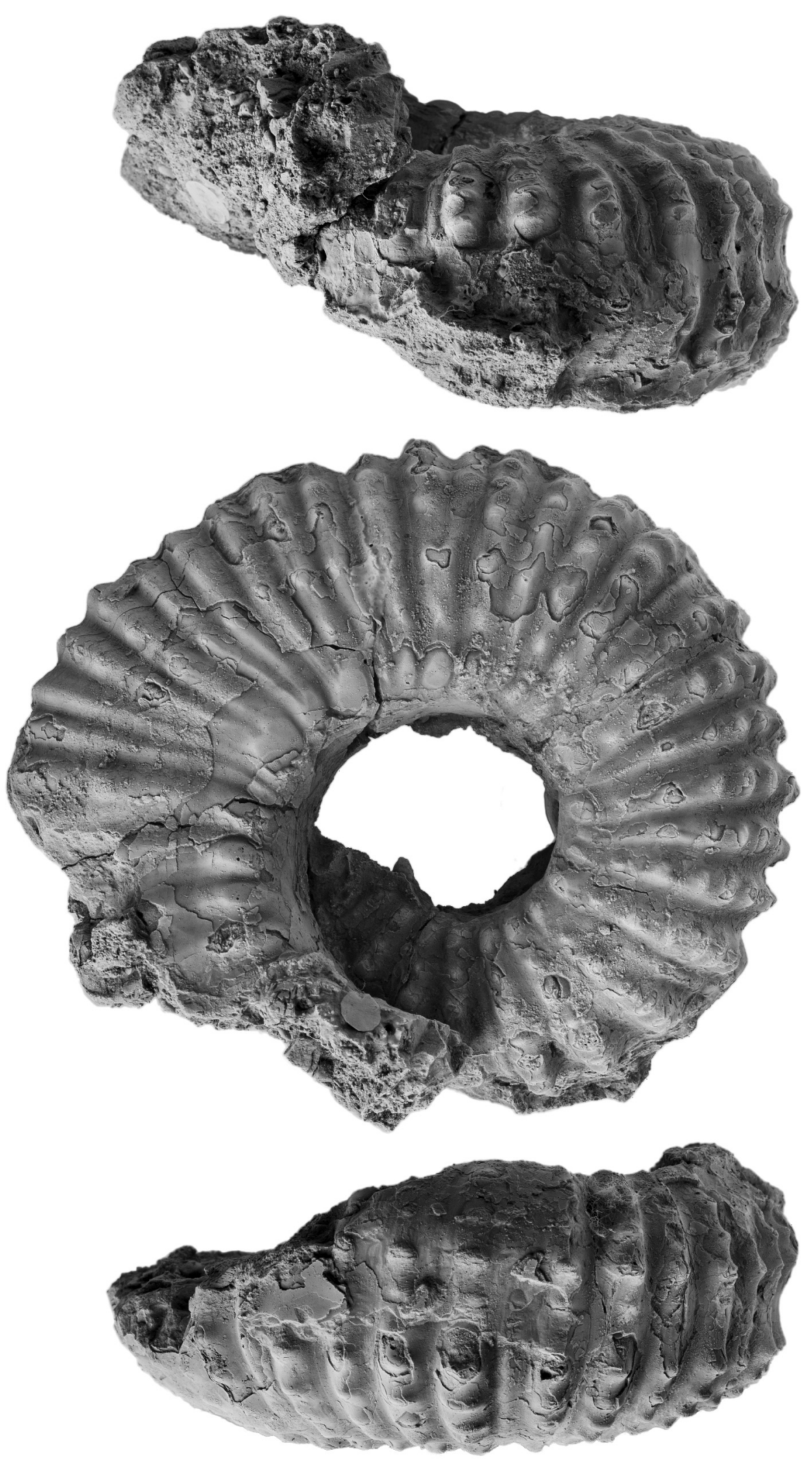

Fig. 2. Douvilleiceras leightonense Casey, 1962. The holotype, BMNH C84735, from the condensed Lower Albian regularis-mammillatum nodule bed of Arnold's Pit, Billington Crossing, Leighton Buzzard, Bedfordshire, England. Figures are $\times 1$. 

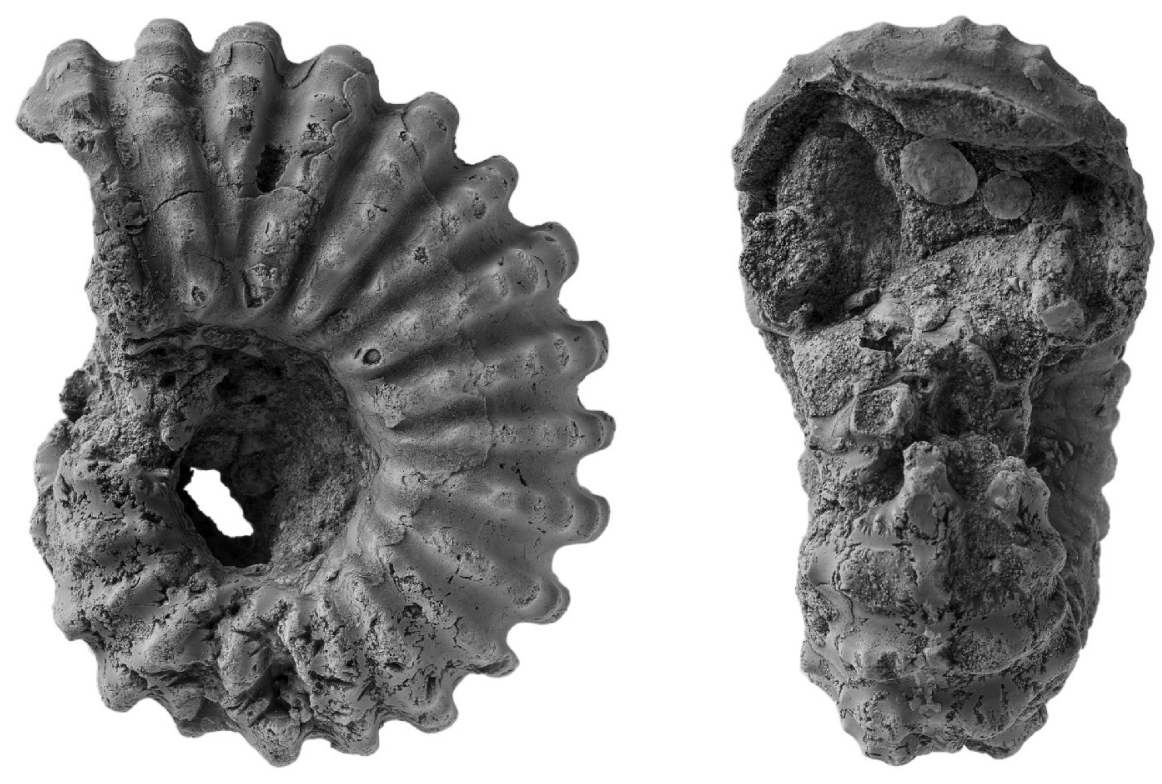

Fig. 3. Douvilleiceras mammillatum (Schlotheim, 1813). The neotype, BMNH C12491, from the condensed main mammillatum nodule bed, Copt Point, Folkestone, Kent, England. Figures are $\times 1$. 

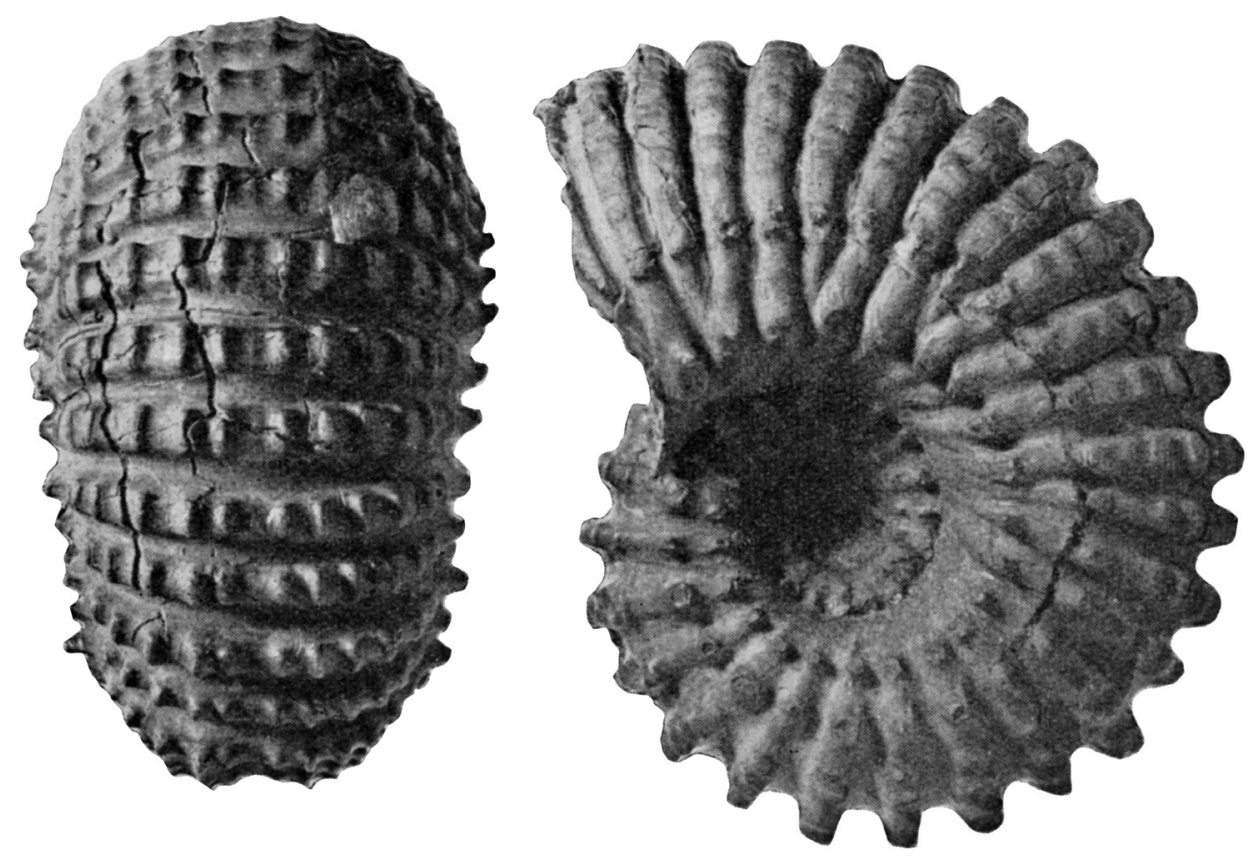

Fig. 4. Douvilleiceras mammillatum (d'Orbigny, 1841). The holotype of Douvilleiceras albense Spath, 1923, no. F7727 in the collections of the Sedgwick Museum, Cambridge, from the lower Middle Albian of Dienville, Aube, France. Copy of Casey 1962, text-fig. 92 on p. 263. Figures are $\times 1$. 

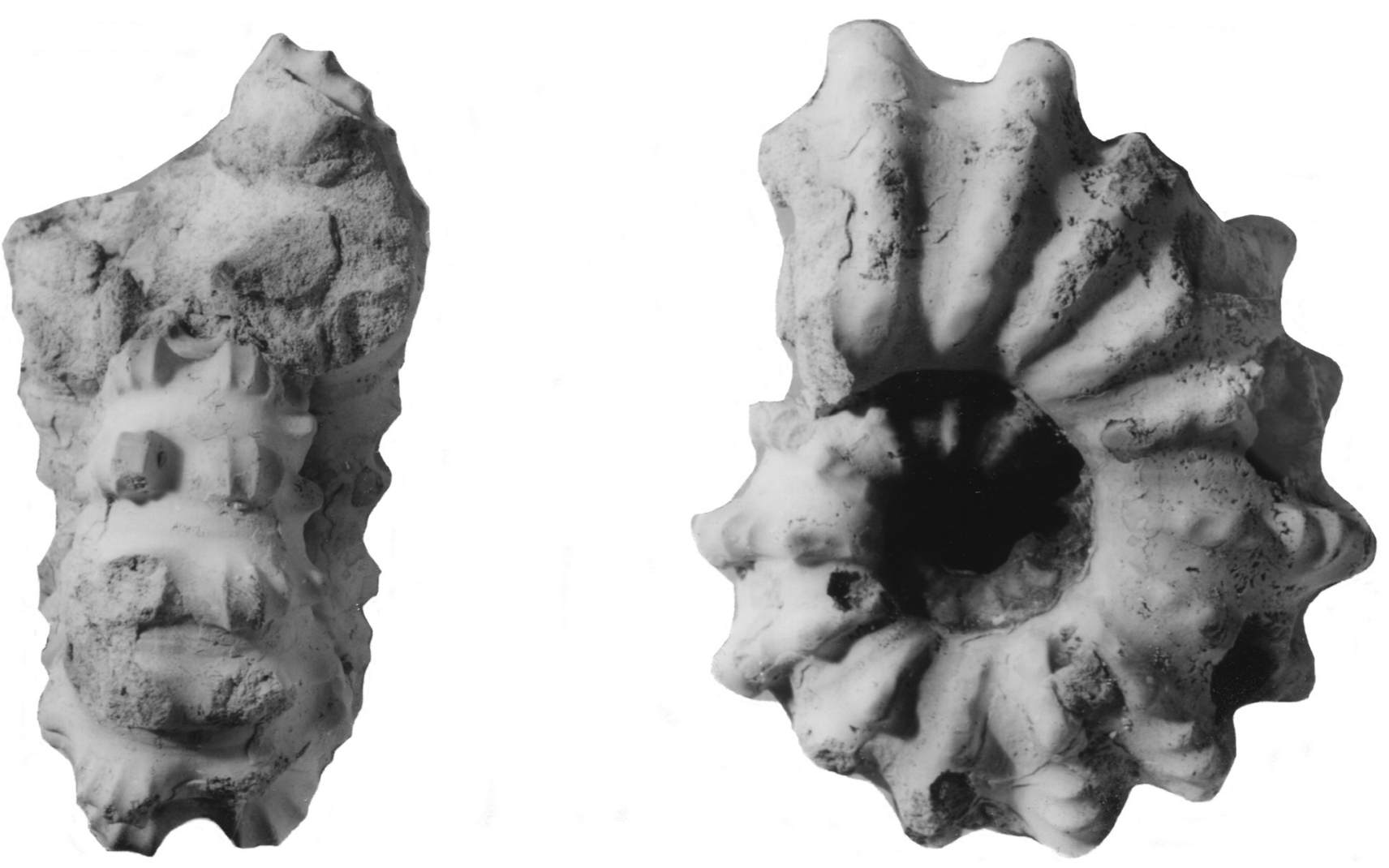

Fig. 5. Douvilleiceras inaequinodum (Quenstedt, 1849). The neotype of Douvilleiceras orbignyi Hyatt, 1903, a synonym, from the condensed Albian of Machéroménil, Ardennes, France, the original of Bayle 1878, pl. 60, fig. 4, in the collections of the École des Mines, Paris, currently housed in the collections of the Université Claude-Bernard, Lyon. Figures are $\times 1$. 


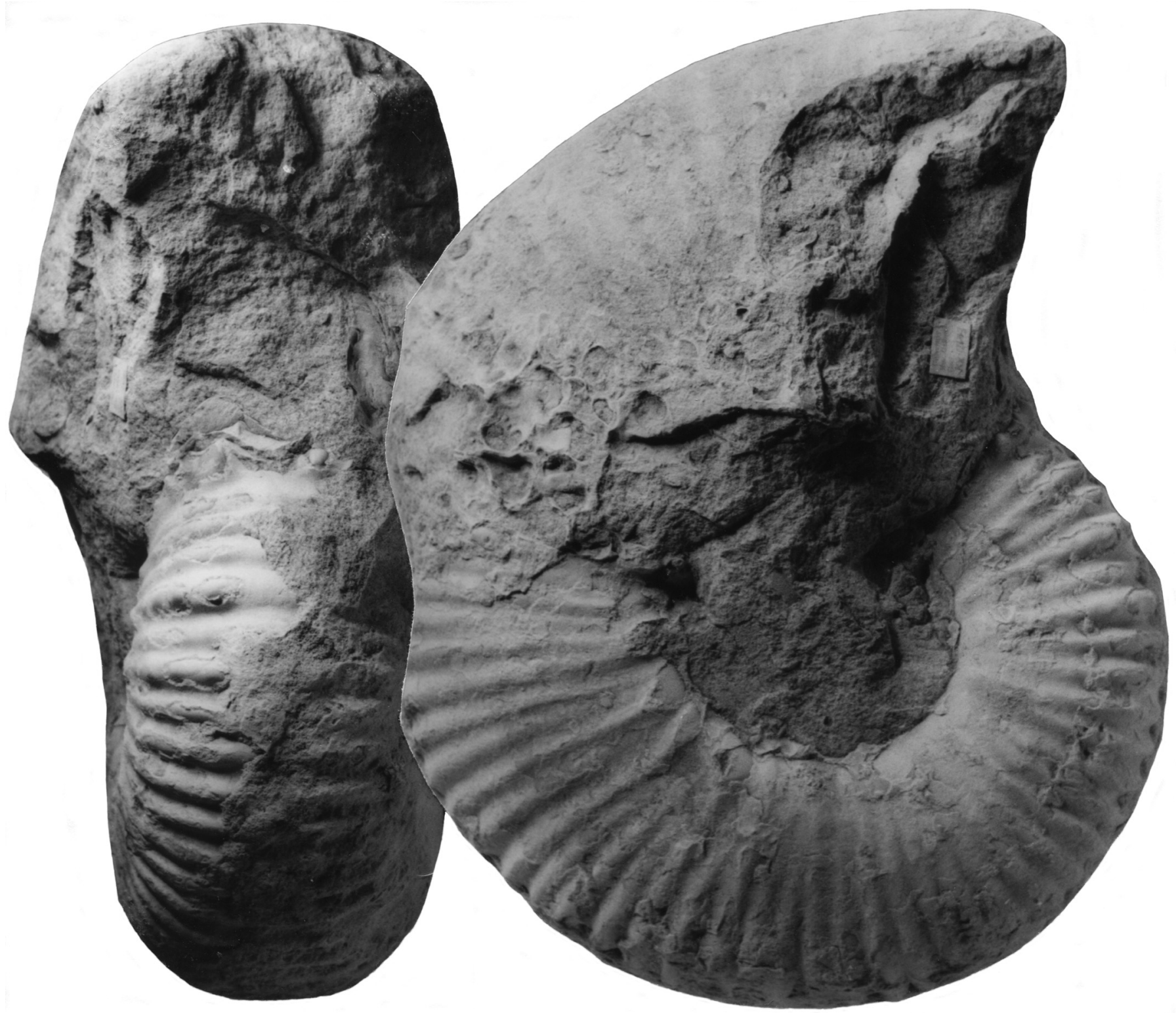

Fig. 6. Douvilleiceras mammillatum (Schlotheim, 1813). OUM KX12643, a macroconch phragmocone from locality 53 . Figures are $\times 1$.

Fig. 7. Douvilleiceras mammillatum (Schlotheim, 1813). An incomplete macroconch, the original of Bayle, 1878, pl. 59, fig. 1, from Dienville, Aube, France, retaining recrystallized shell. The original is in the collections of the École des Mines, Paris, currently housed in the collections of the Université Claude-Bernard, Lyon. Figures are $\times 0.95$. 

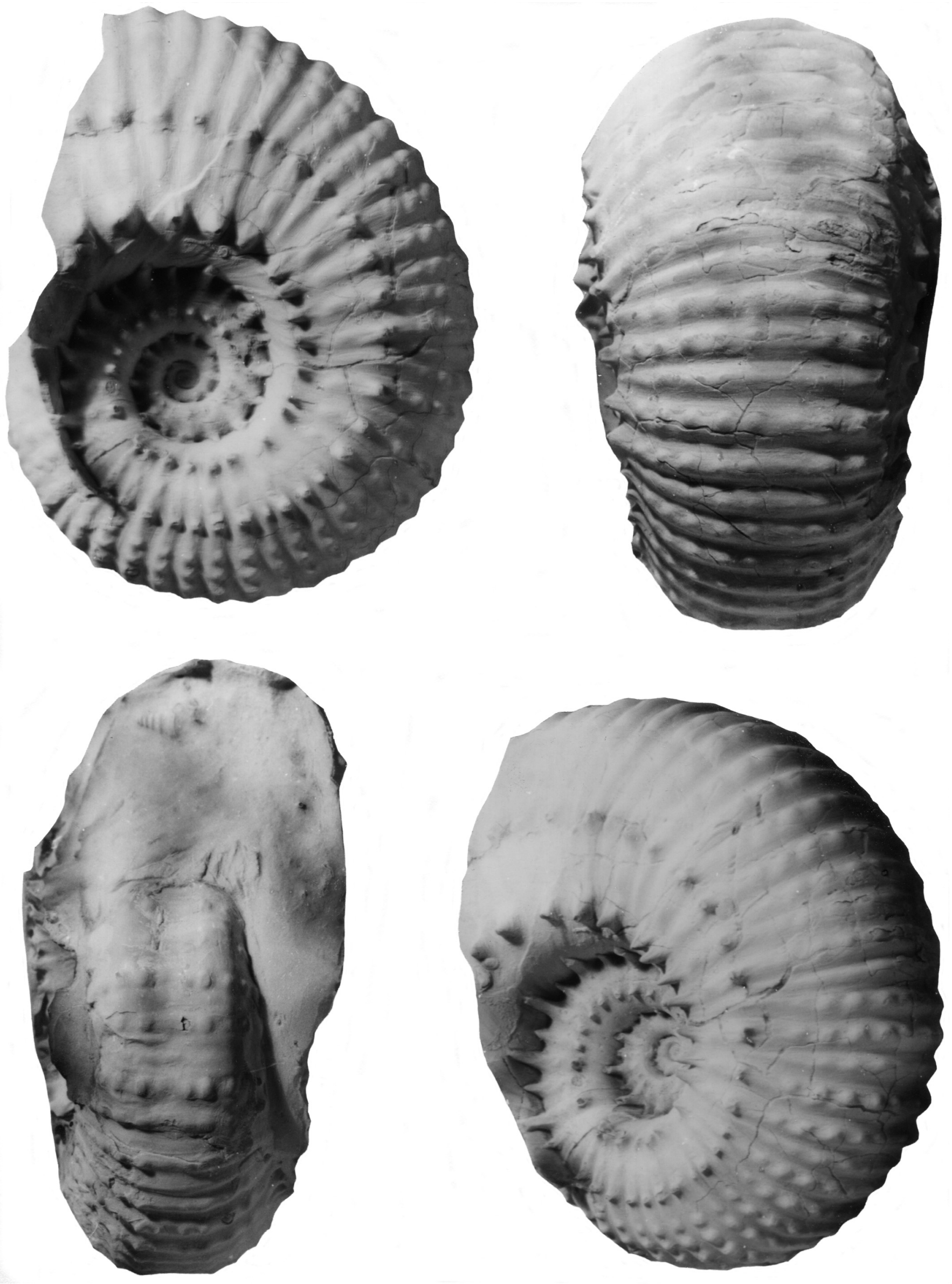

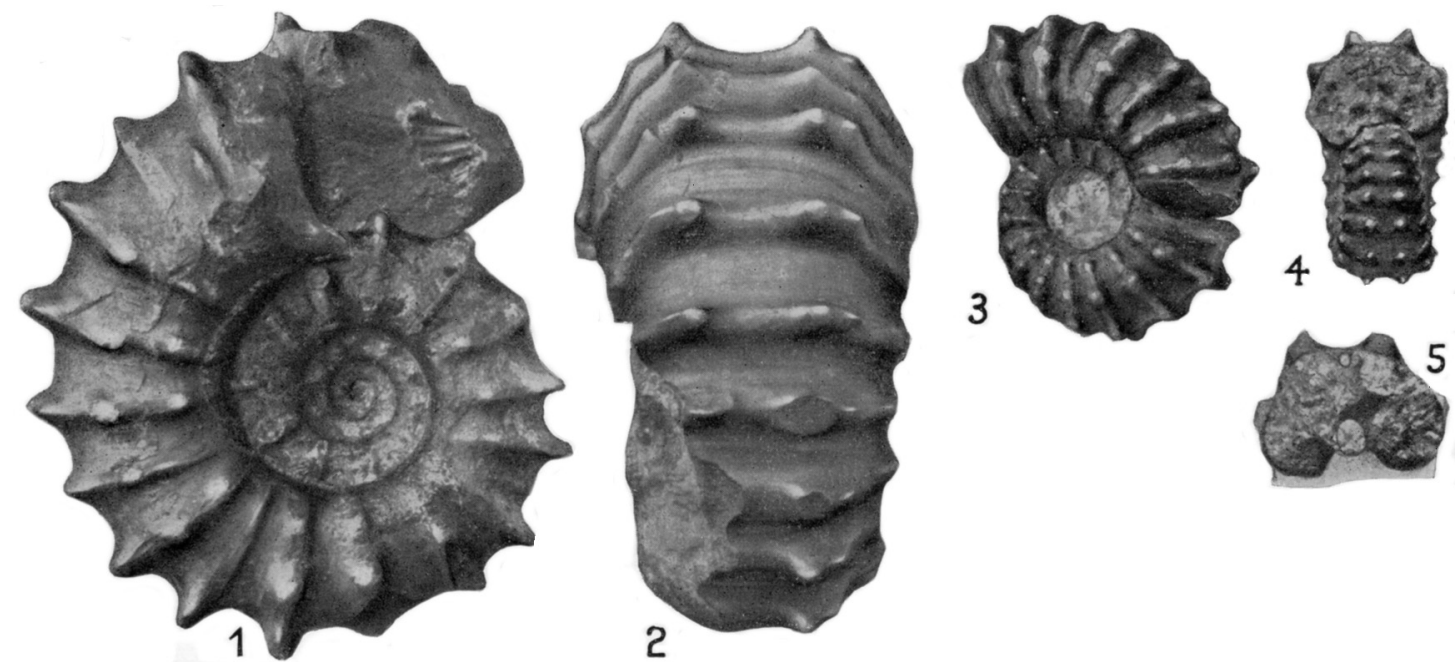

Fig. 8. 1, 2, Copy of Riedel, 1938, p. 29, pl. 6, figs 1, 2, the holotype of Douvilleiceras horridum Riedel, 1938, the type species of Eodouvilleiceras Casey, 1962, said to be from the Upper Aptian, Utica, Colombia. 3-5, Douvilleiceras horridum n. sp. ?, Copy of Riedel, 1938, p. 29, pl. 6, figs 3-5, from Quebrada Negra, south of Utica, Colombia. The figures are said to be reduced $\times 10.9$. 


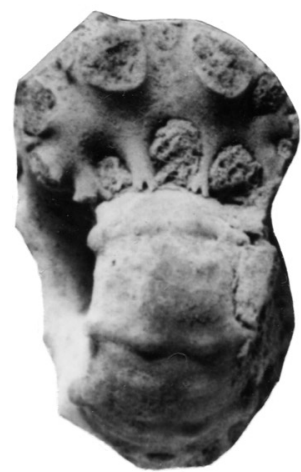

A

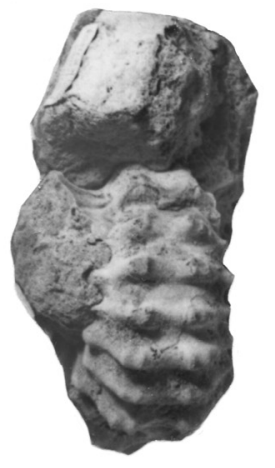

$\mathbf{F}$

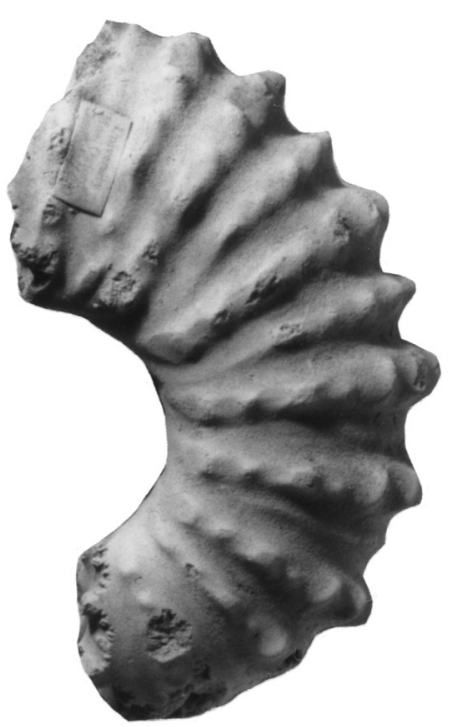

K

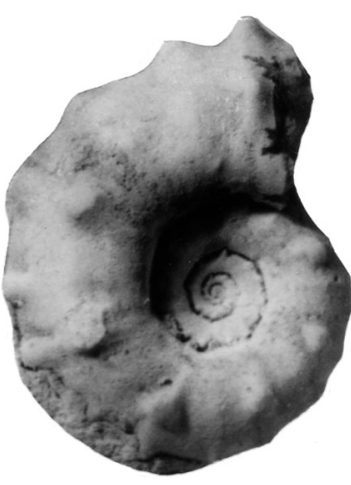

B

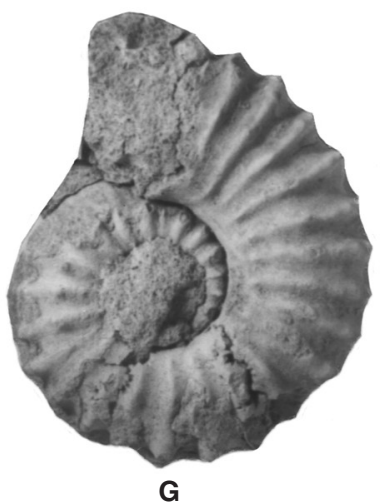

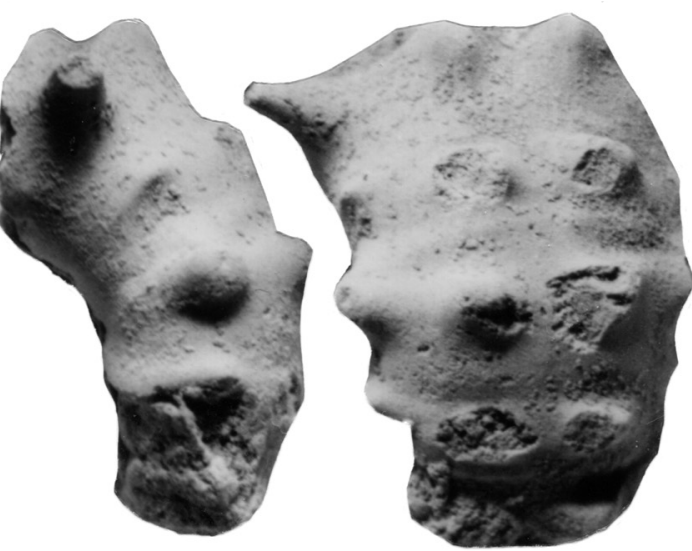

D

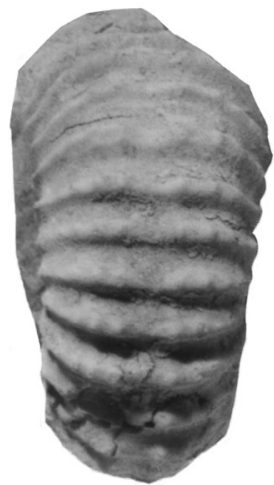

H

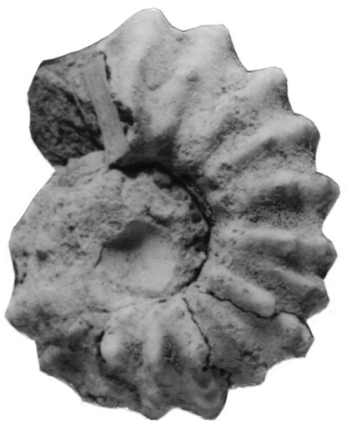

I
E

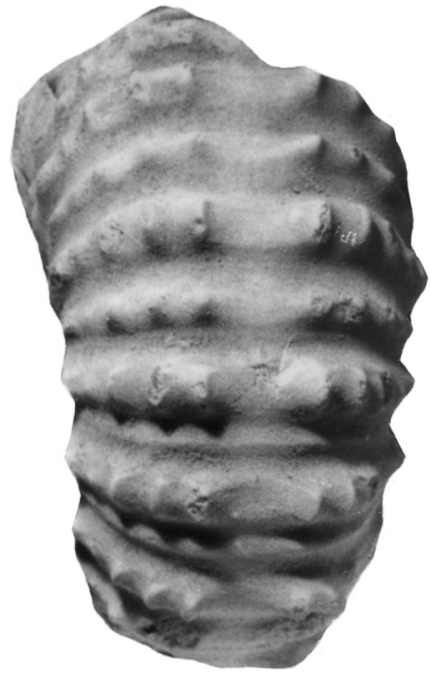

$\mathbf{L}$

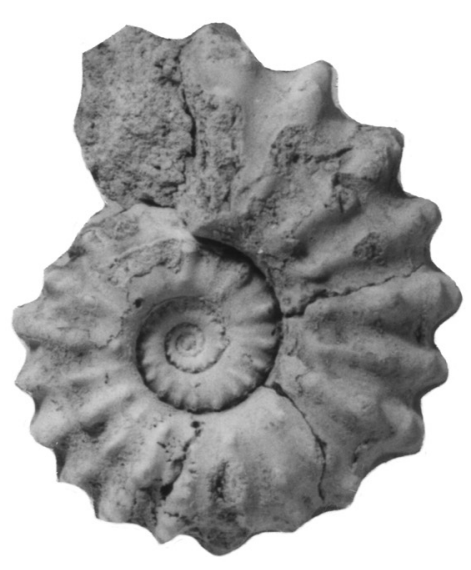

$\mathbf{M}$

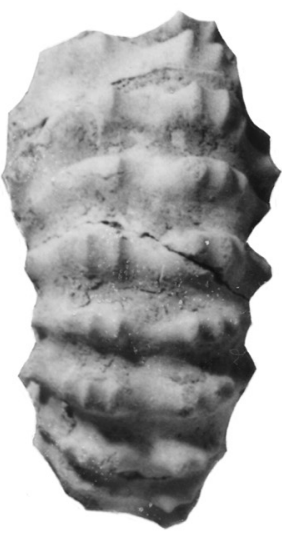

N

Fig. 9. Douvilleiceras mammillatum (Schlotheim, 1813). A-C, OUM KX11021; D, E, OUM KX10995; F-H, OUM KX11011; I, J, OUM KX11012; K, L, OUM KX11010; M, N, OUM KX11008, all from locality 35. Figures A-E are $\times 2 ; \mathrm{K}-\mathrm{N}$ are $\times 1$. 


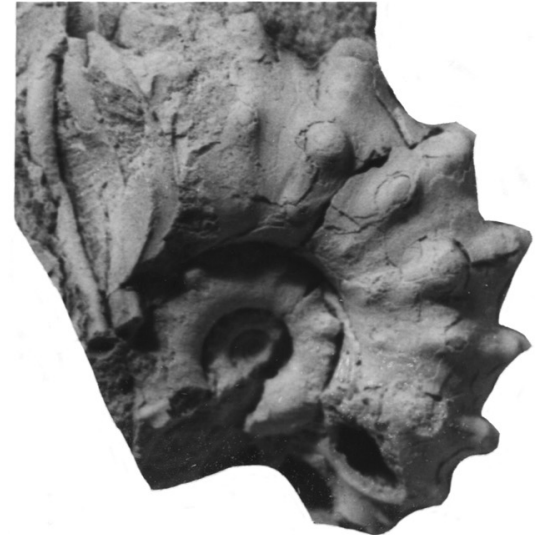

A

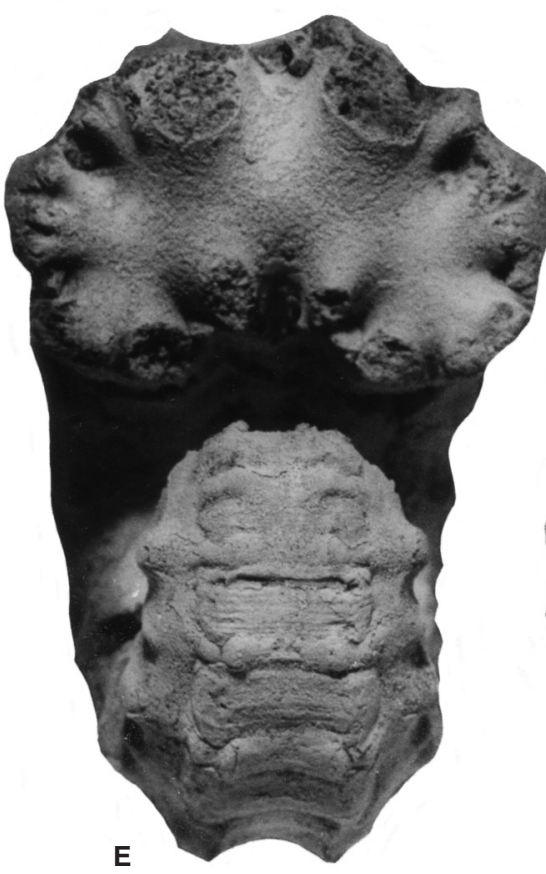

Fig 10. Douvilleiceras mammillatum (Schlotheim,

E-G, OUM KX10999, from locality 35, with well-preserved dorsal callosity. All figures are $\times 2$.

B

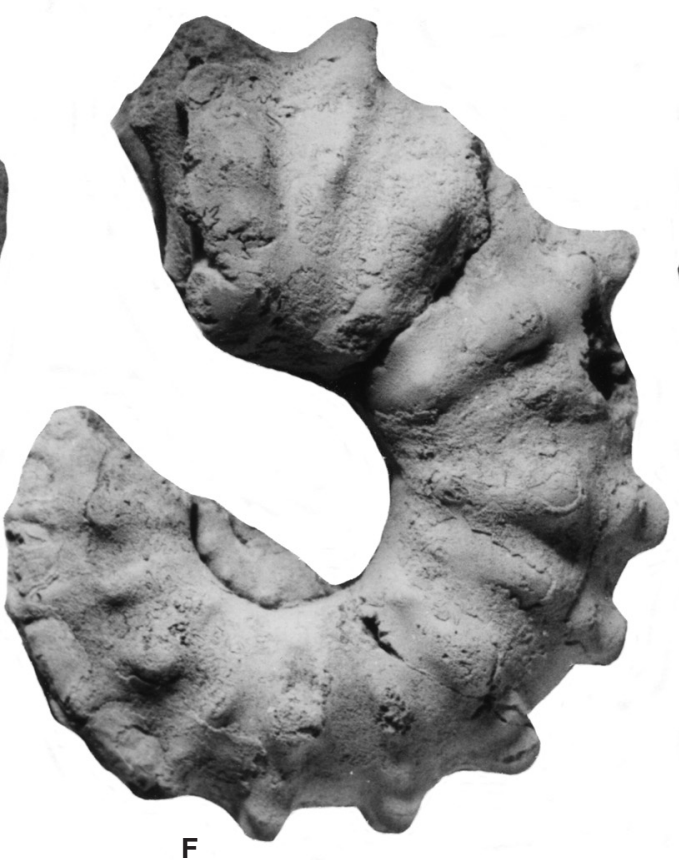

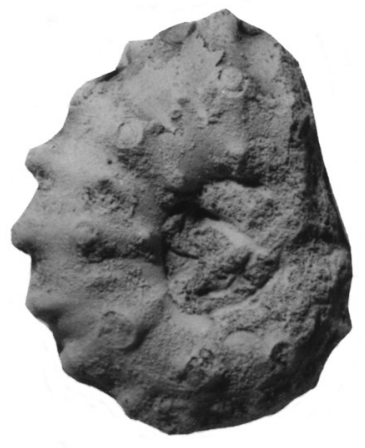

C

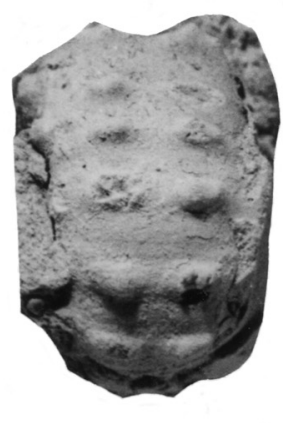

D

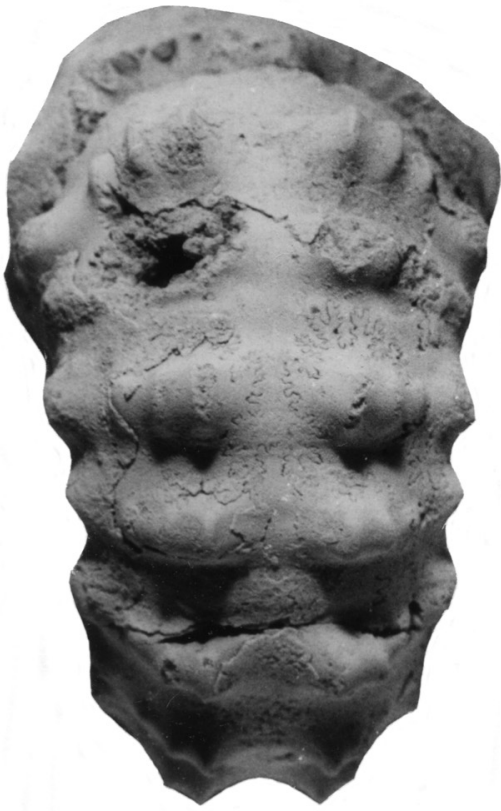

G

Fig. 11. A-C, M-O, Douvilleiceras mammillatum (Schlotheim, 1813). A-C, OUM KX4856; M-O, OUM KX4872, with well-preserved dorsal callosity, both from locality 53; D-L, Douvilleiceras inaequinodum (Quenstedt, 1849). D, H, OUM KX5808, from locality 142; E, OUM KX4864; F, G, OUM KX4863; I, J, OUM KX4858; K,L, OUM KX4867, all from locality 53. All figures are $\times 1$. 


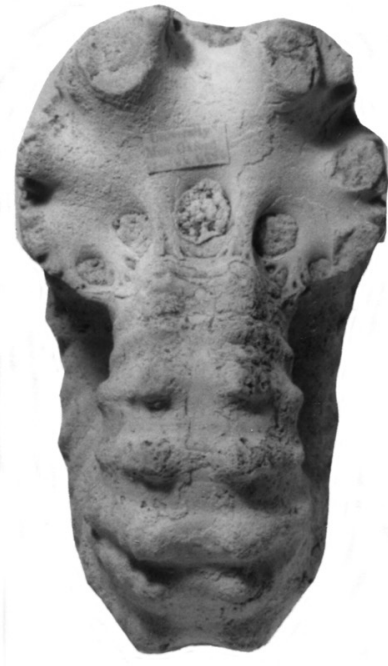

A
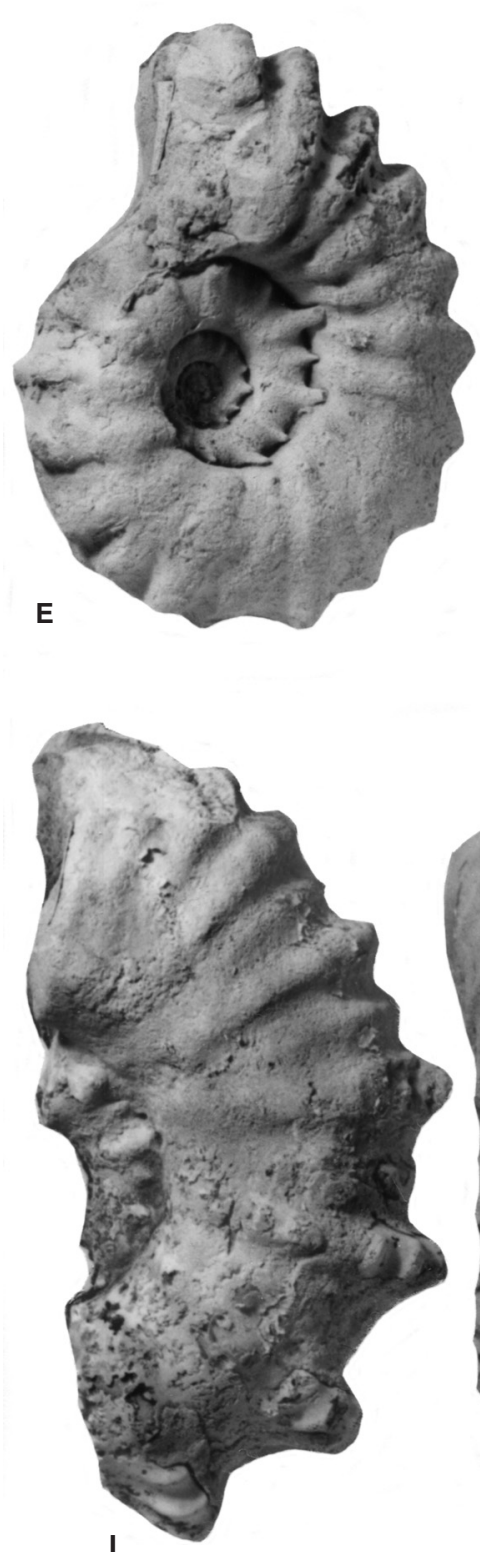

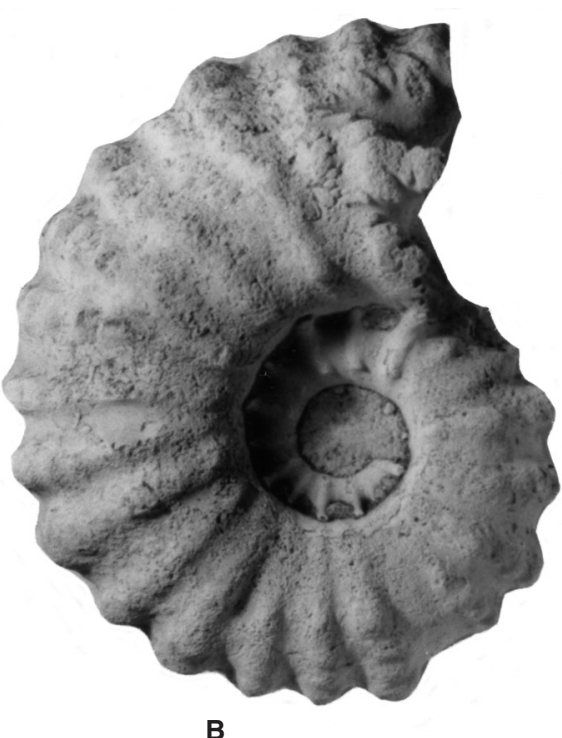

B

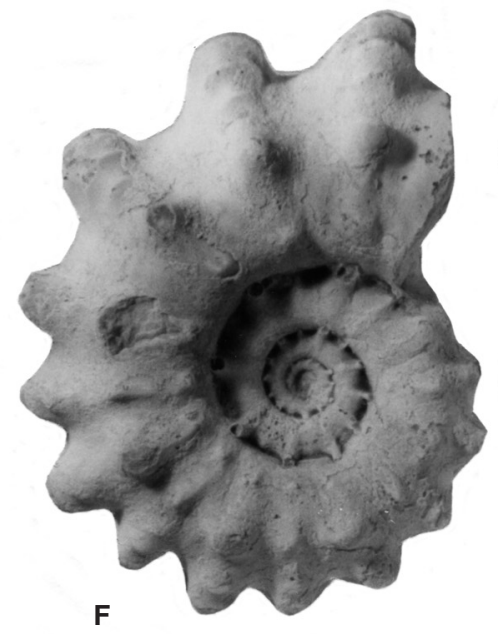

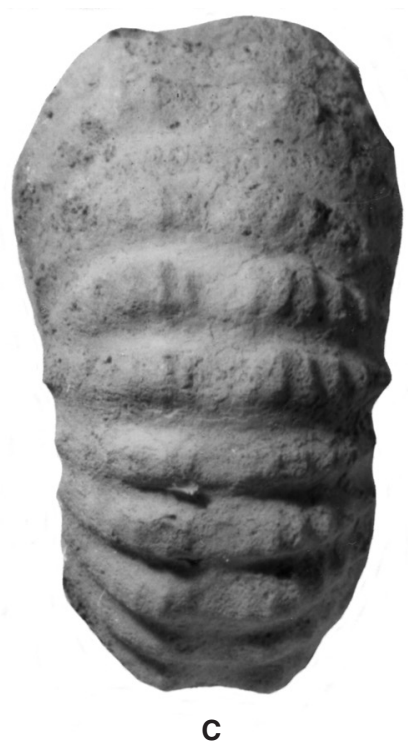
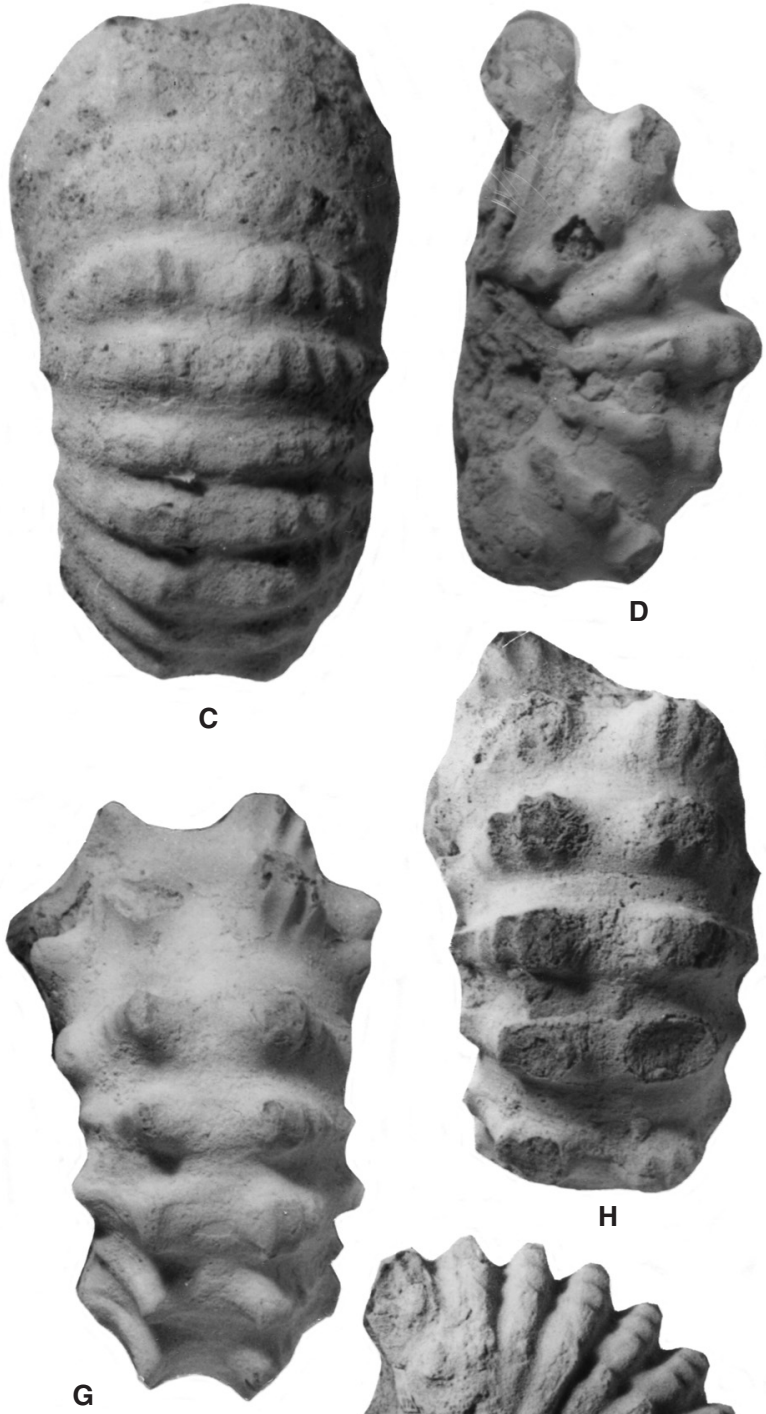

H

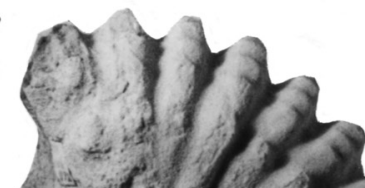

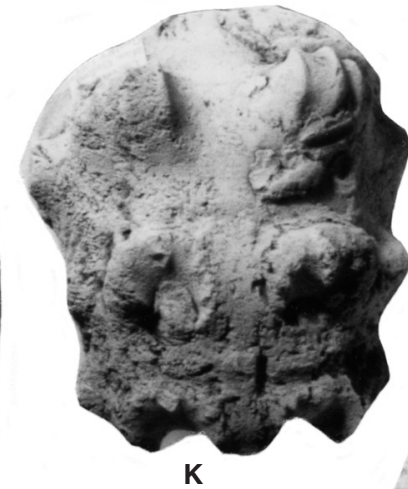

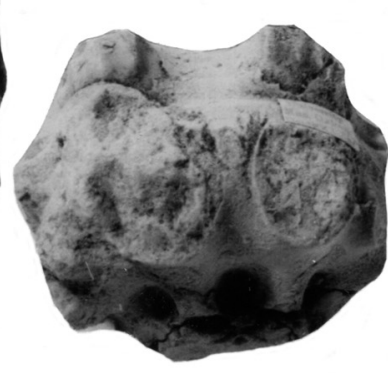

$\mathbf{L}$
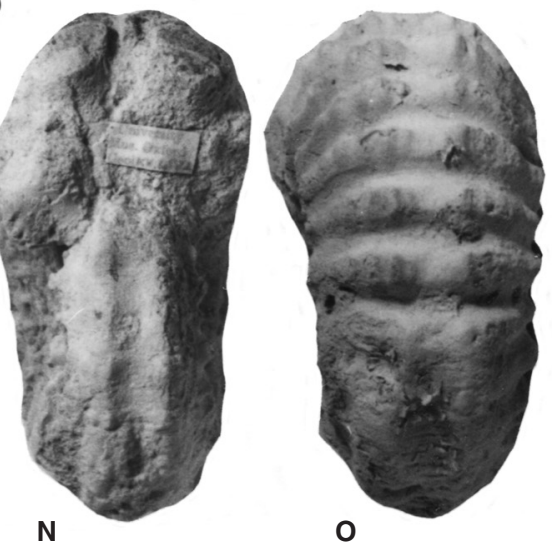


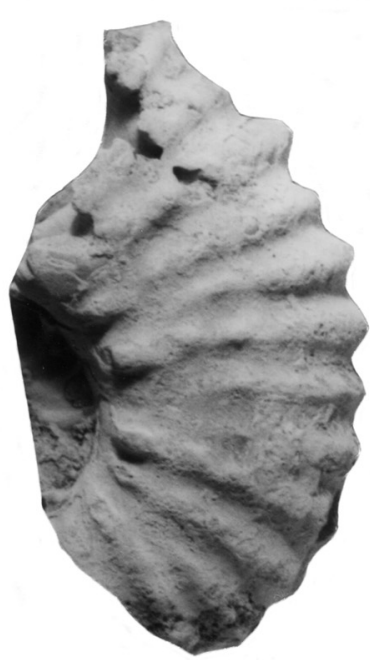

A

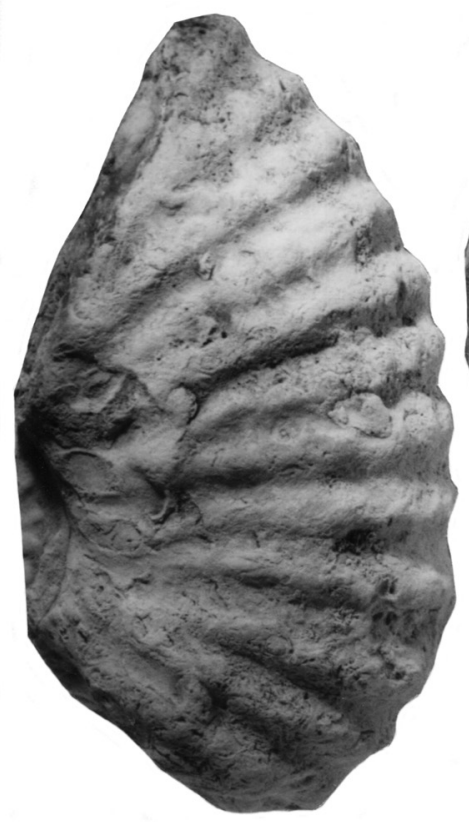

$\mathbf{E}$

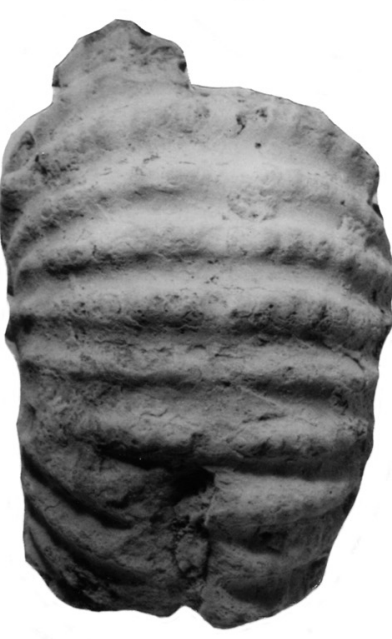

B

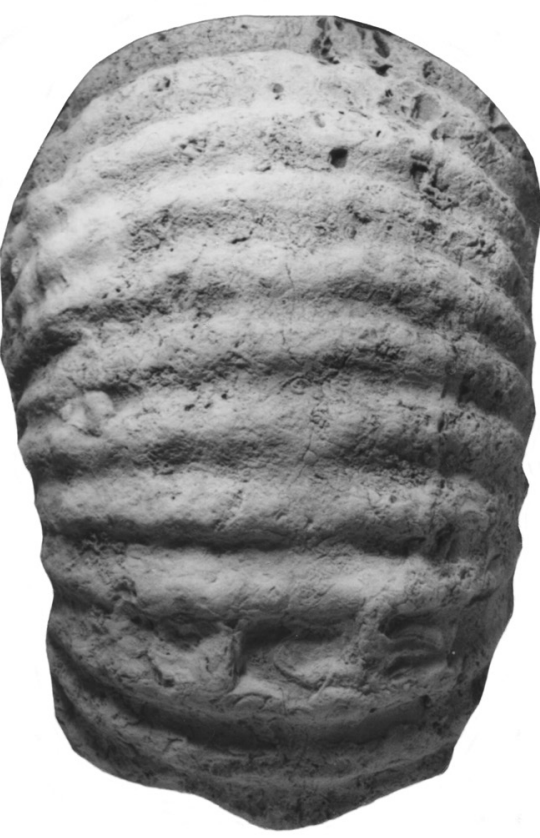

$\mathbf{F}$

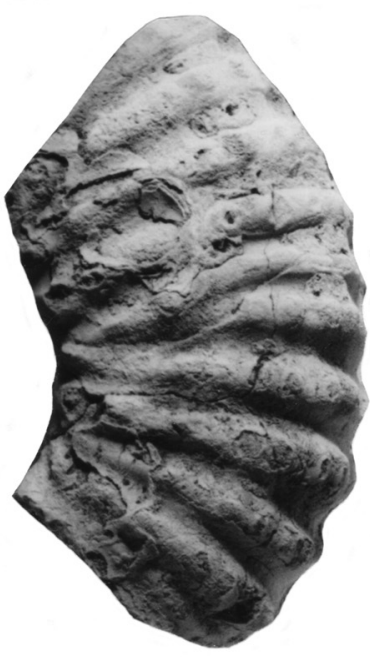

C
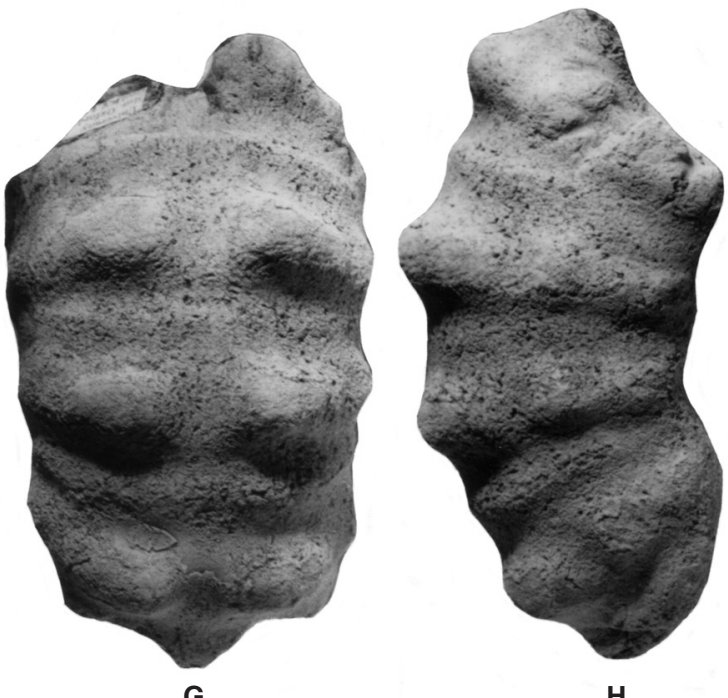

H

Fig. 12. A-F, Douvilleiceras mammillatum (Schlotheim, 1813. A, B, OUM KX4878; C, D, OUM KX4865; E, F, OUM KX4862. G, H, Douvilleiceras inaequinodum (Quenstedt, 1849), OUM KX4876. All specimens are from locality 53. All figures are $\times 1$.

Fig. 13. A-H, Douvilleiceras mammillatum (Schlotheim, 1813). A, B, OUM KX10010; C, D, OUM KX12379, a small microconch, both from locality176; E, F, OUM KX6148, a microconch; G, OUM KX6149, both from locality 142; H, OUM KX9941, from locality 175. I, J, Douvilleiceras inaequinodum (Quenstedt, 1849), OUM KX10006, an incomplete macroconch from locality 176. All figures are $\times 1$. 

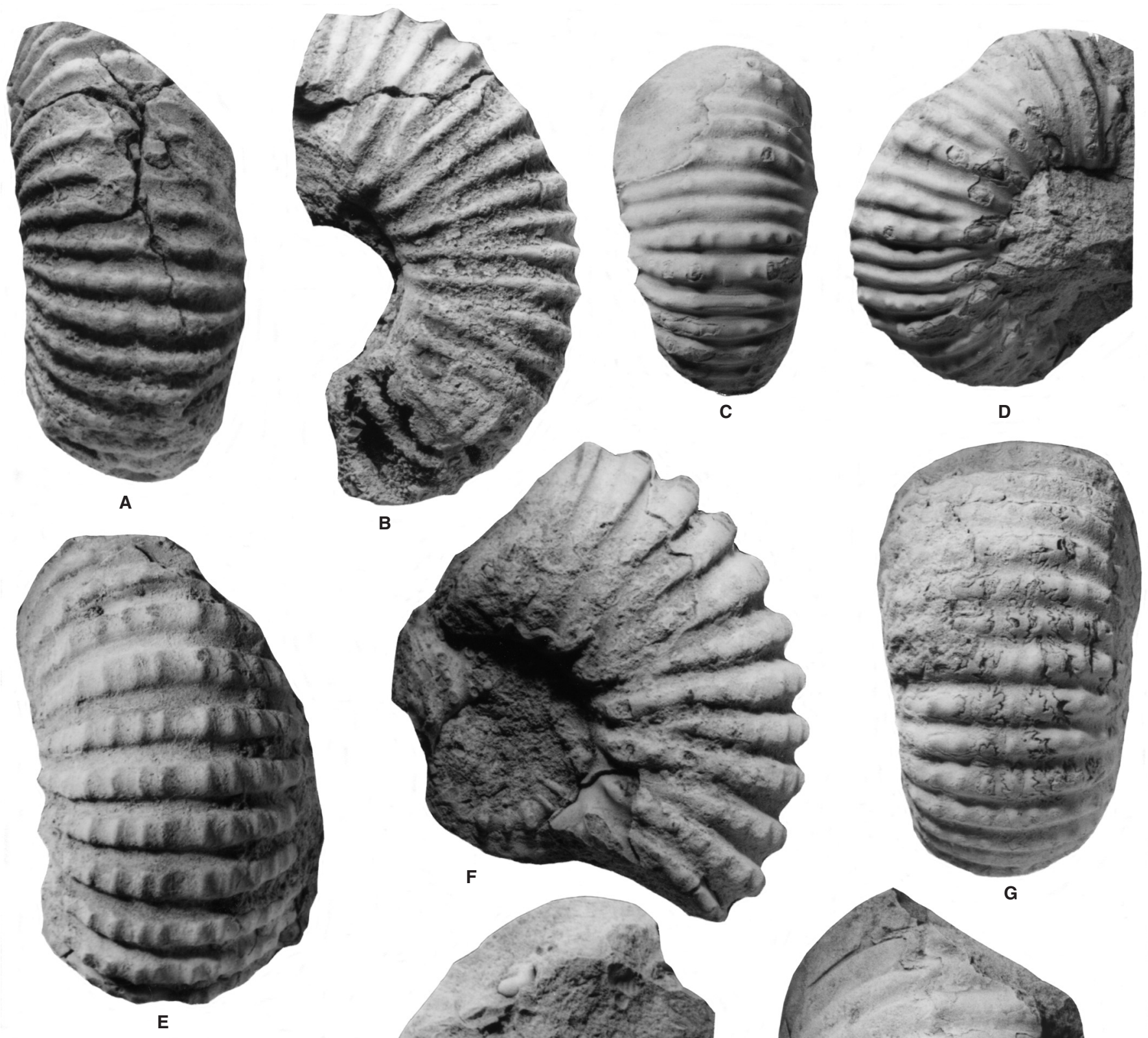


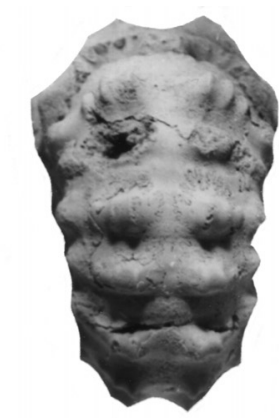

A
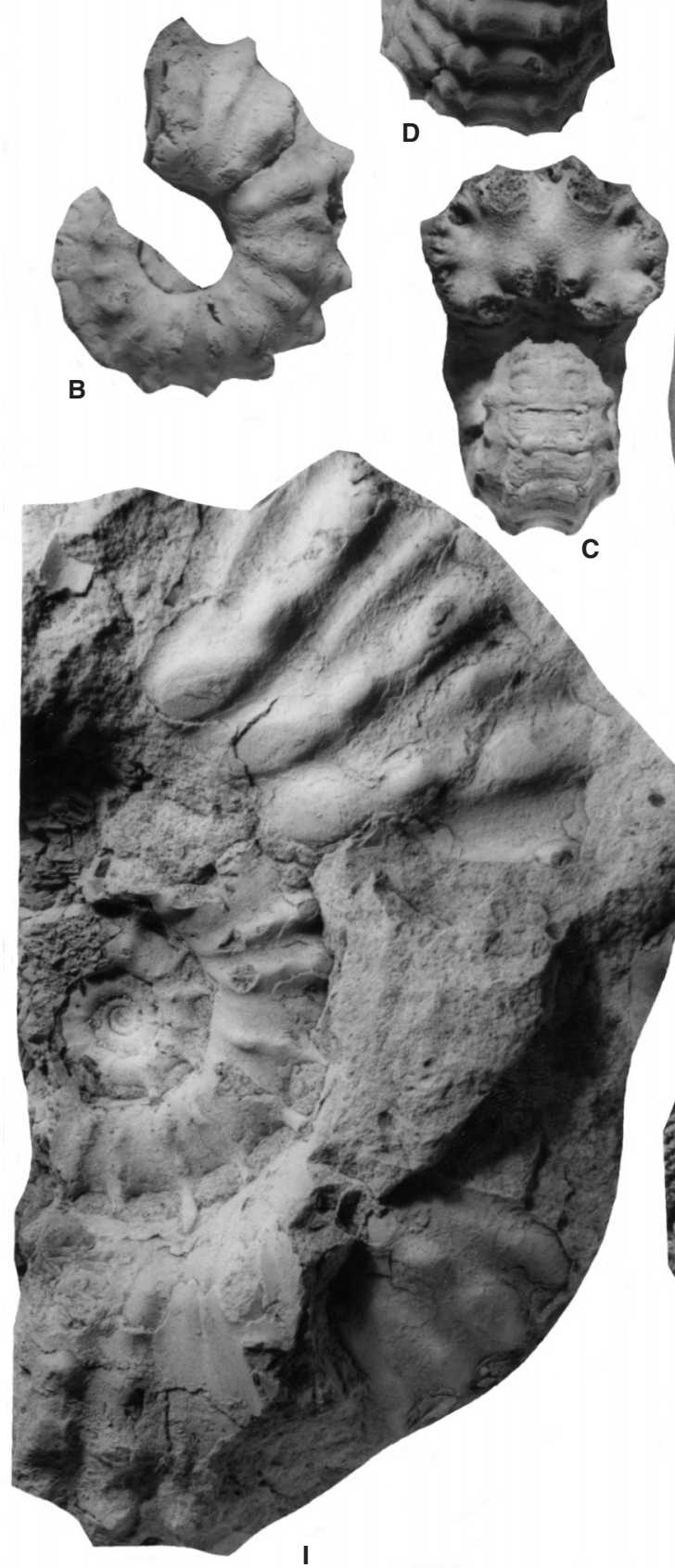

I

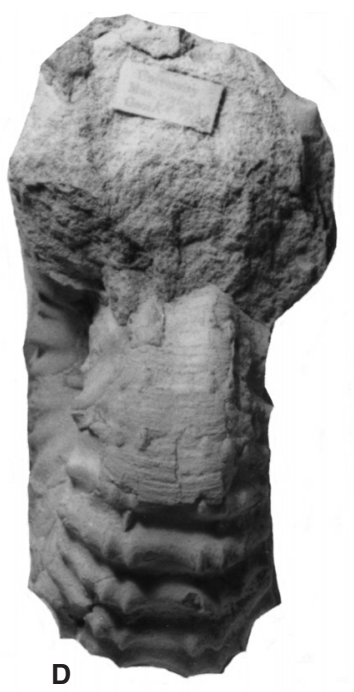

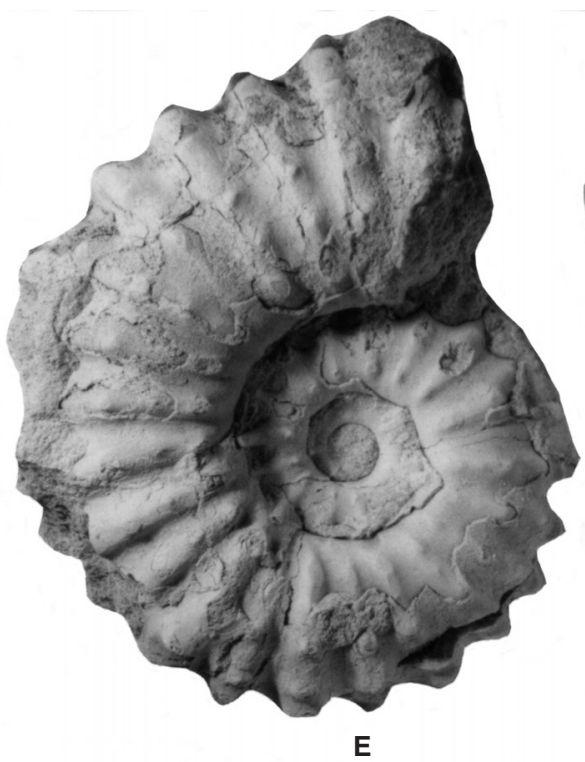
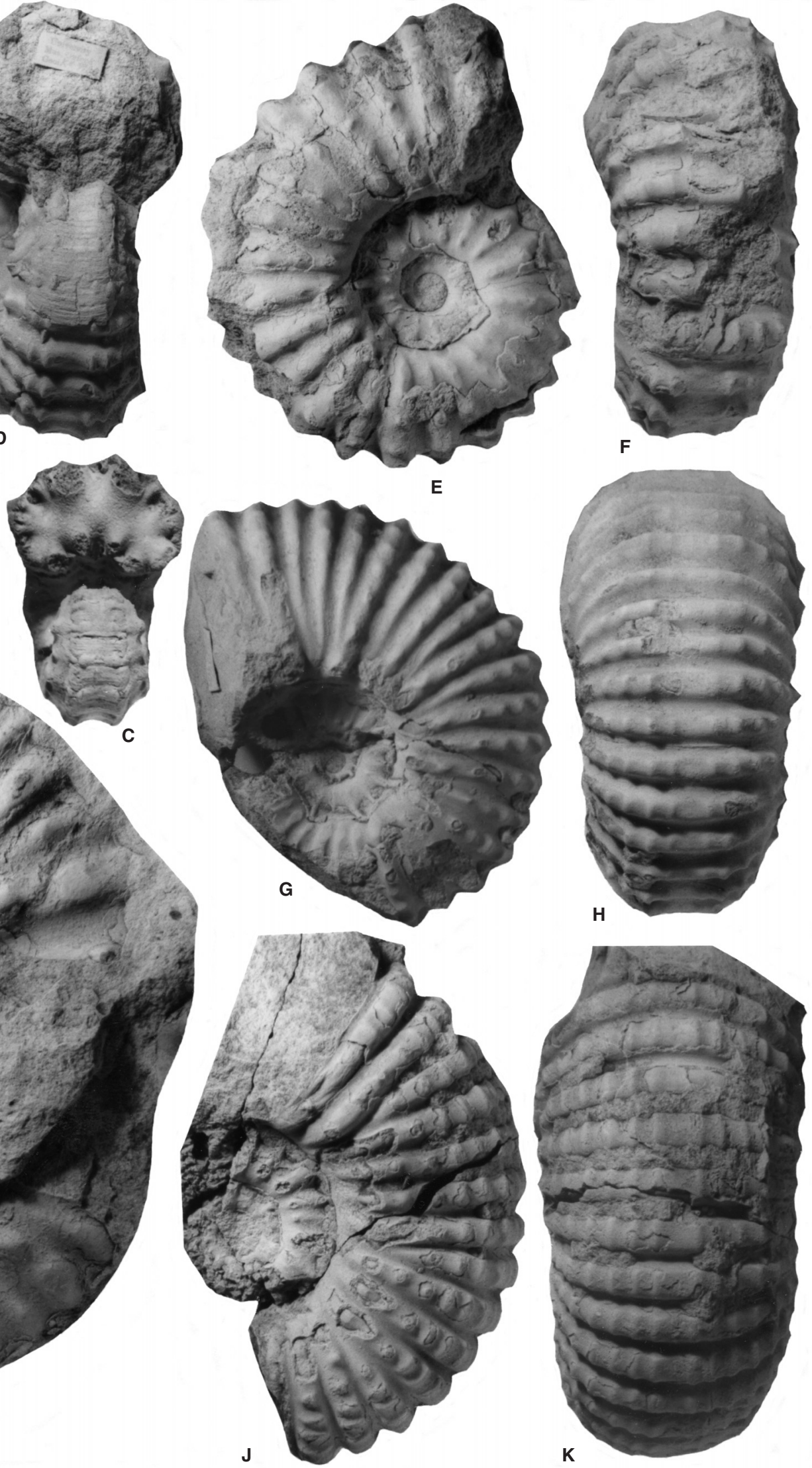

Fig. 14. A-K, Douvilleiceras mammillatum (Schlotheim, 1813). A-C, OUM KX10999, from locality 35, with well-preserved callosity; D-F, OUM KX9930, with well-preserved callosity; G, H, OUM KX9929, a microconch; I, OUM KX9922, an incomplete macroconch, all from locality 174 ; J, K, OUM KX10007, a microconch, from locality 176 . All figures are $\times 0.95$. 


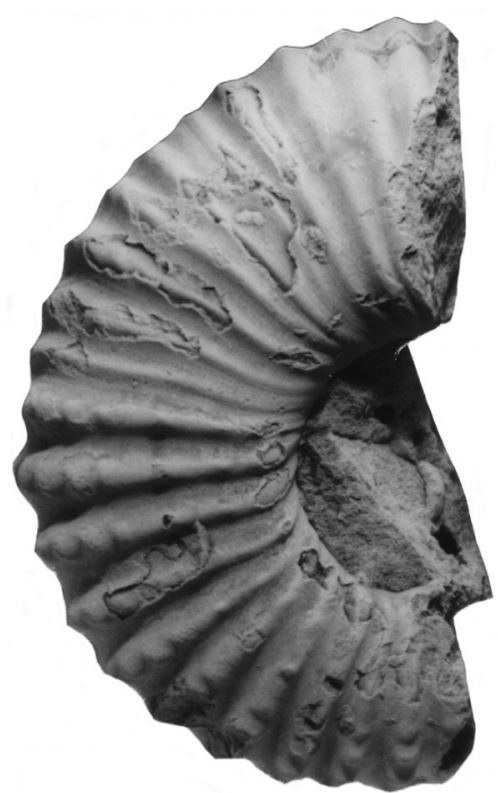

A

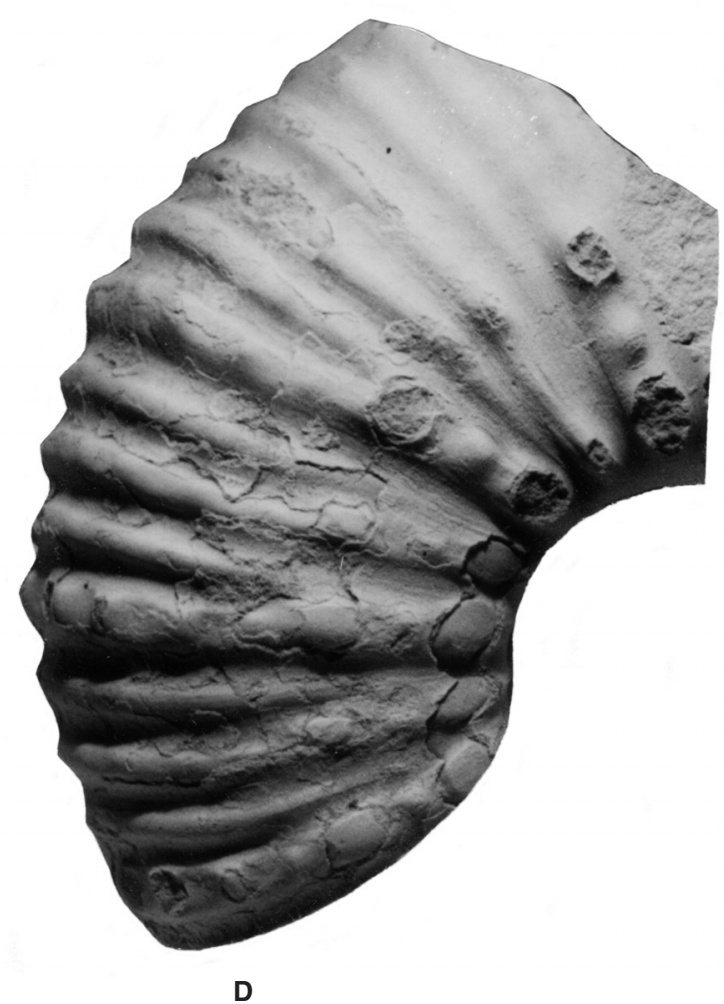

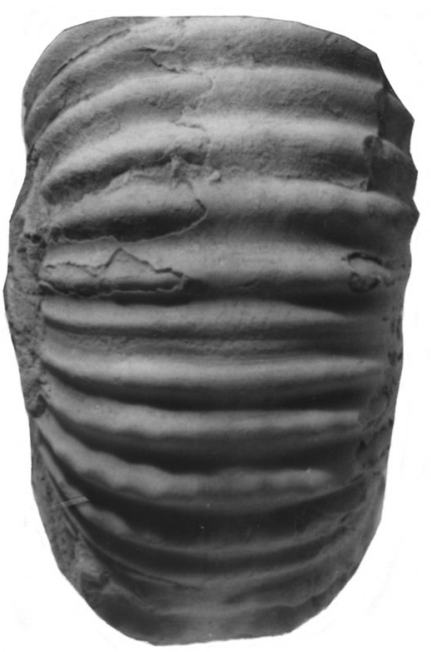

B

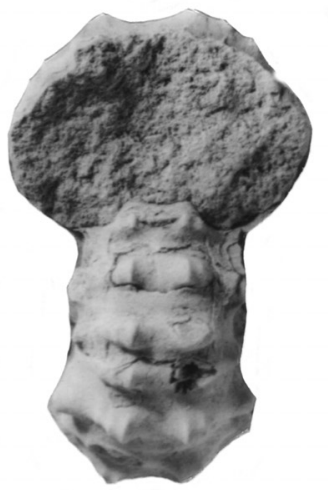

E

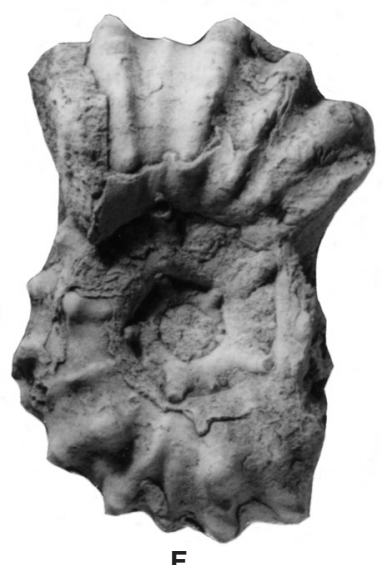

$\mathbf{F}$

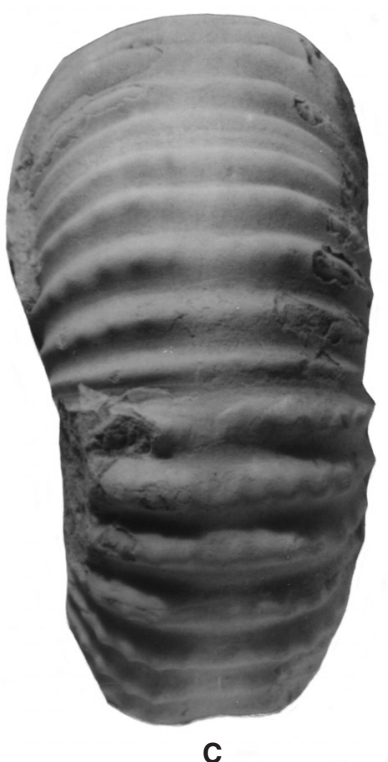

C

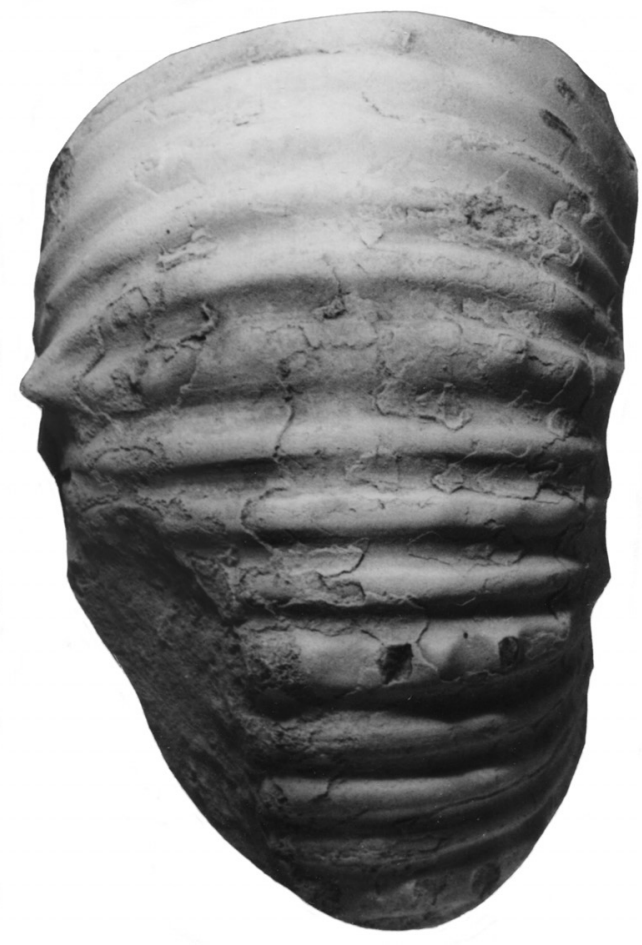

G

Fig. 15. A-G, Douvilleiceras mammillatum (Schlotheim,1813). A-C, OUM KX9924/7, a microconch; D, G, OUM KX9923, a macroconch; E-F, OUM KX9932, all from locality 174 . All figures are $\times 1$. 


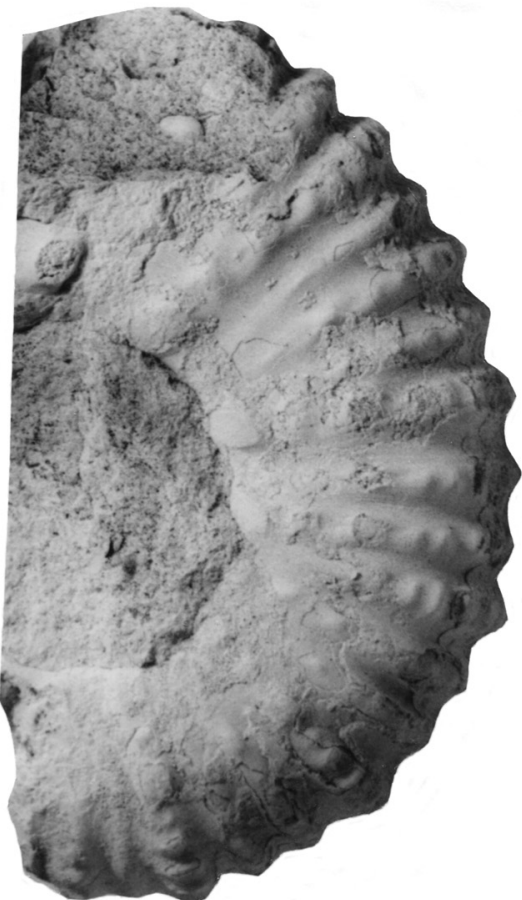

A

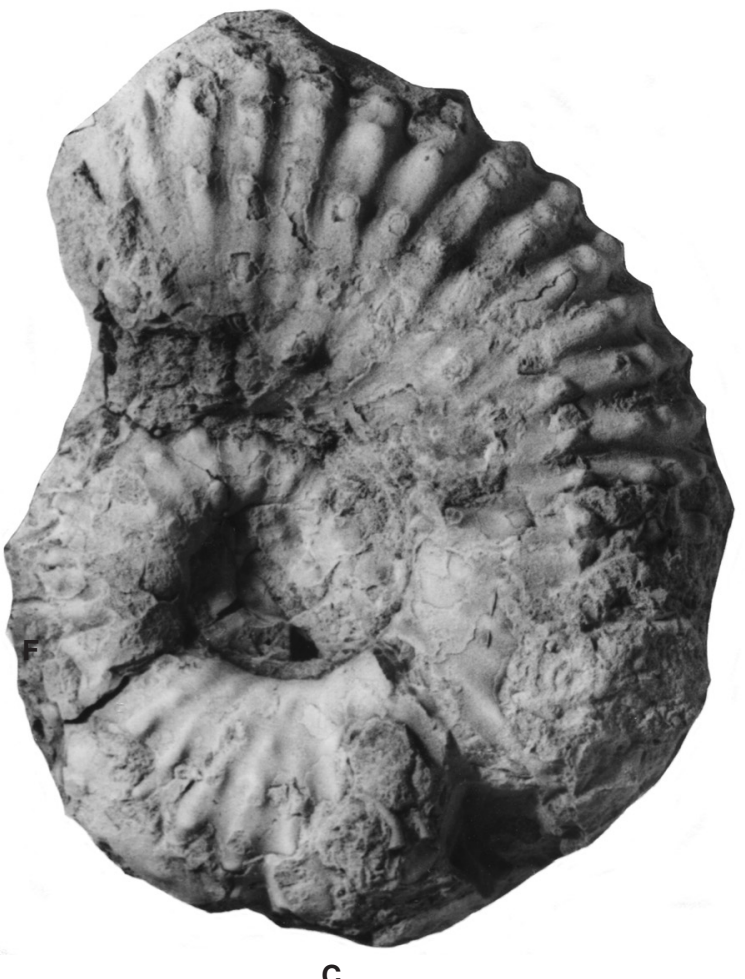

C
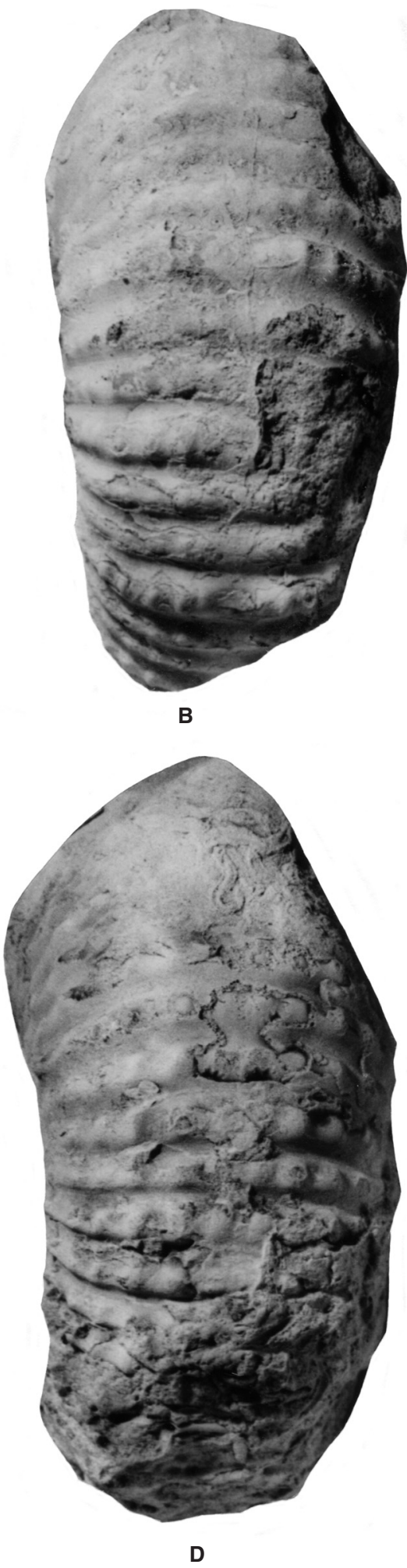

Fig. 16. A-D, Douvilleiceras mammillatum (Schlotheim, 1813). A, B, OUM KX9943, from locality 175; C, D, OUM KX9882, from southwest of Ndumu. All figures are $\times 1$. 


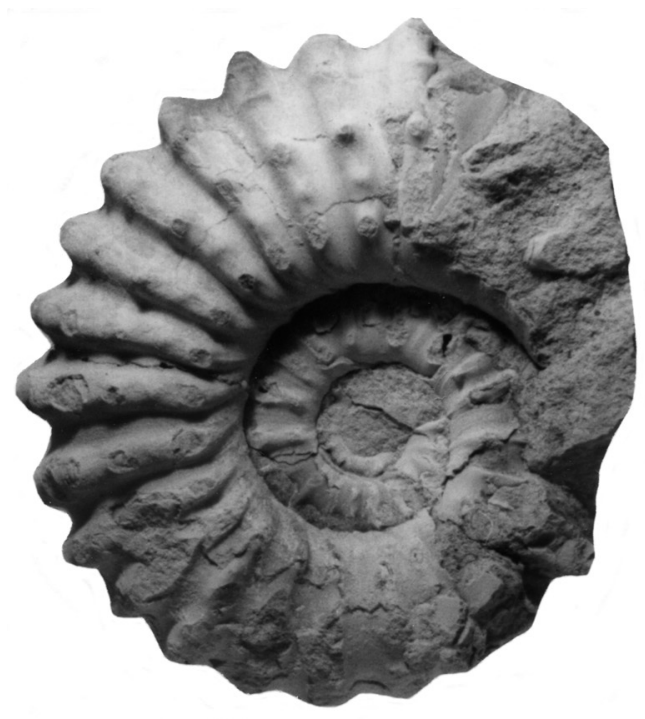

A

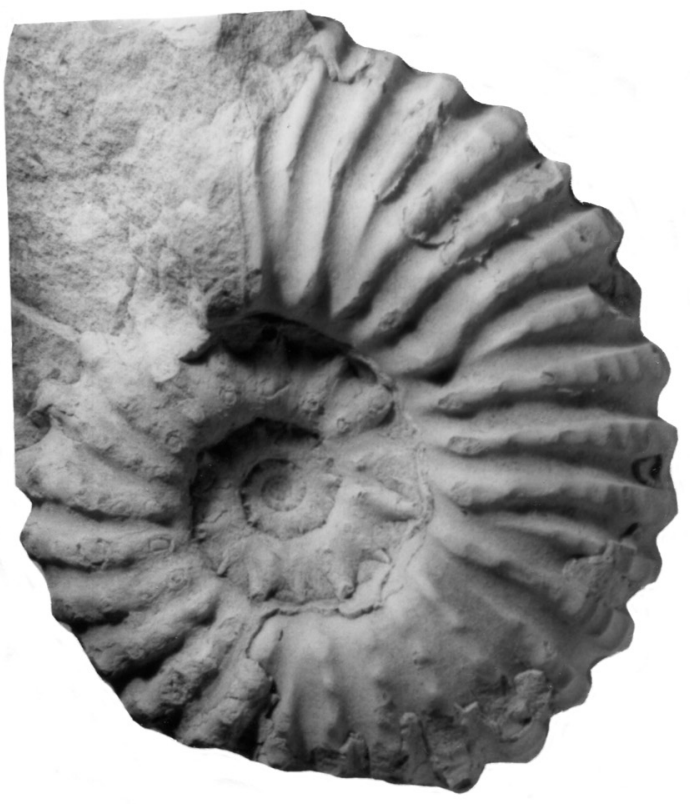

$\mathbf{F}$

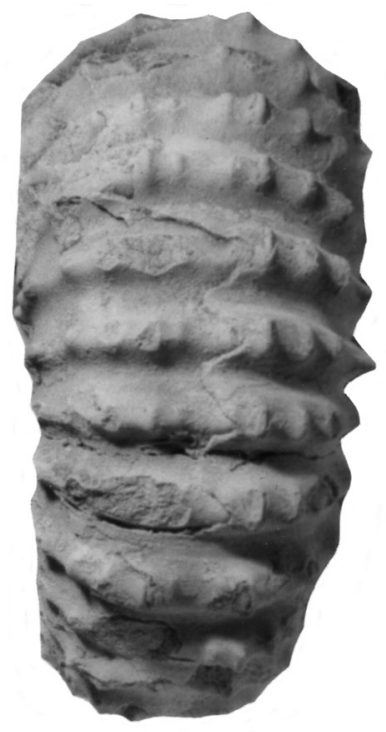

B

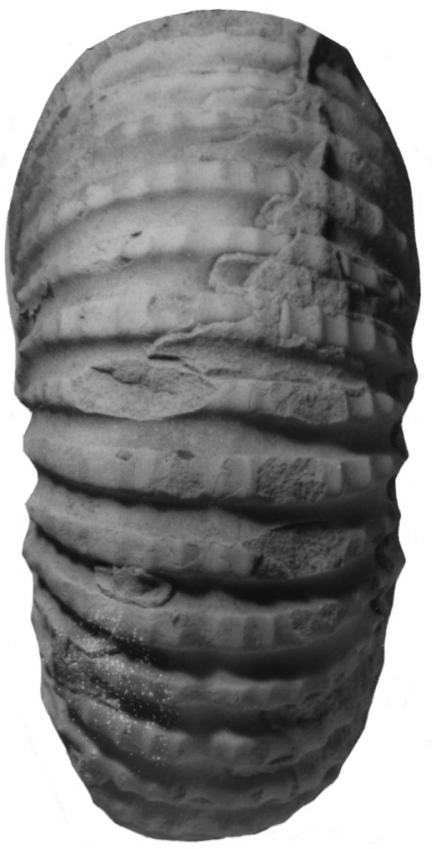

G

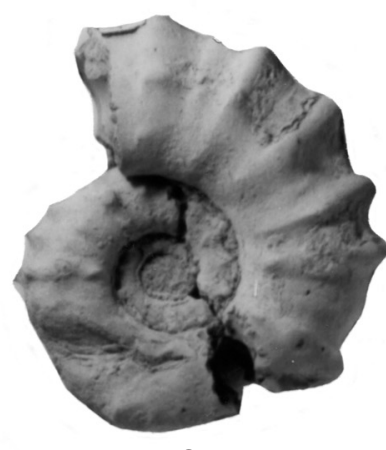

C
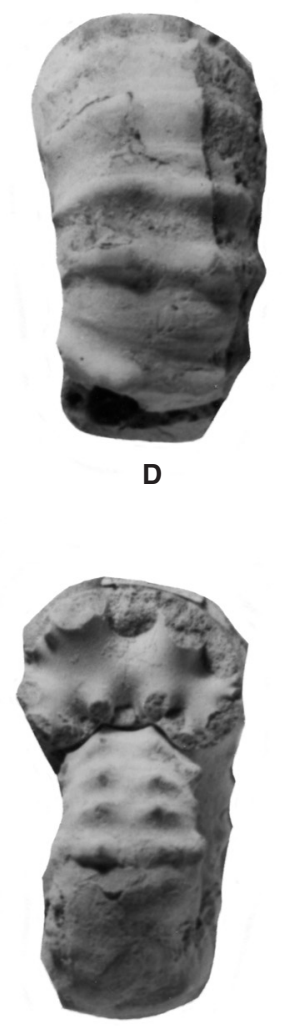

E

Fig. 17. A-E, Douvilleiceras mammillatum (Schlotheim, 1813). A, B, OU KX9883; C-E, OUM KX9885; F, G, OUM KX9881, a microconch, all from southwest of Ndumu. All figures are $\times 1$. 

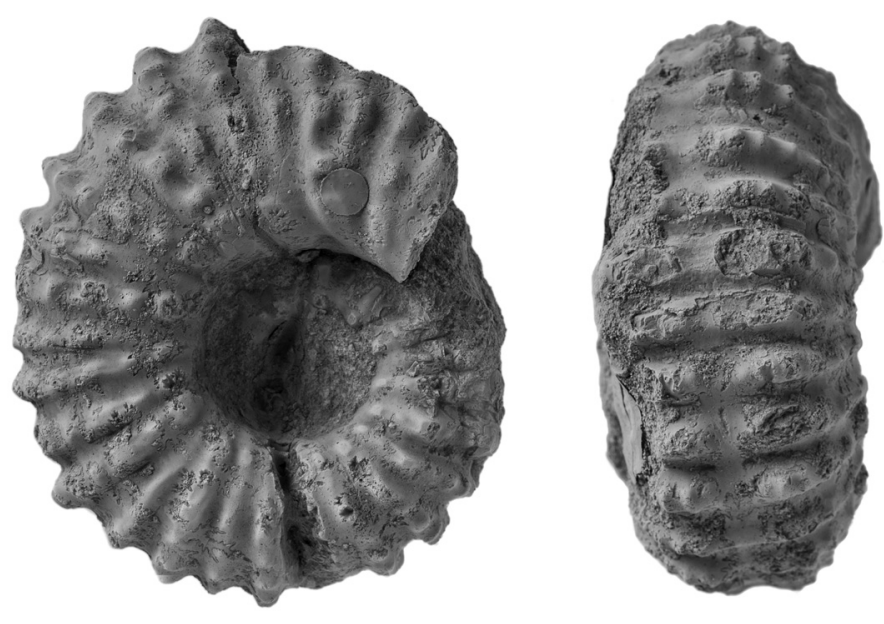

Fig. 18. Douvilleiceras mammillatum (Schlotheim, 1813), BMNH C43941a, the lectotype of Douvilleiceras monile (J. Sowerby, 1816), said to be from Sandgate, near Folkestone, Kent, England. Figures are $\times 1$. 

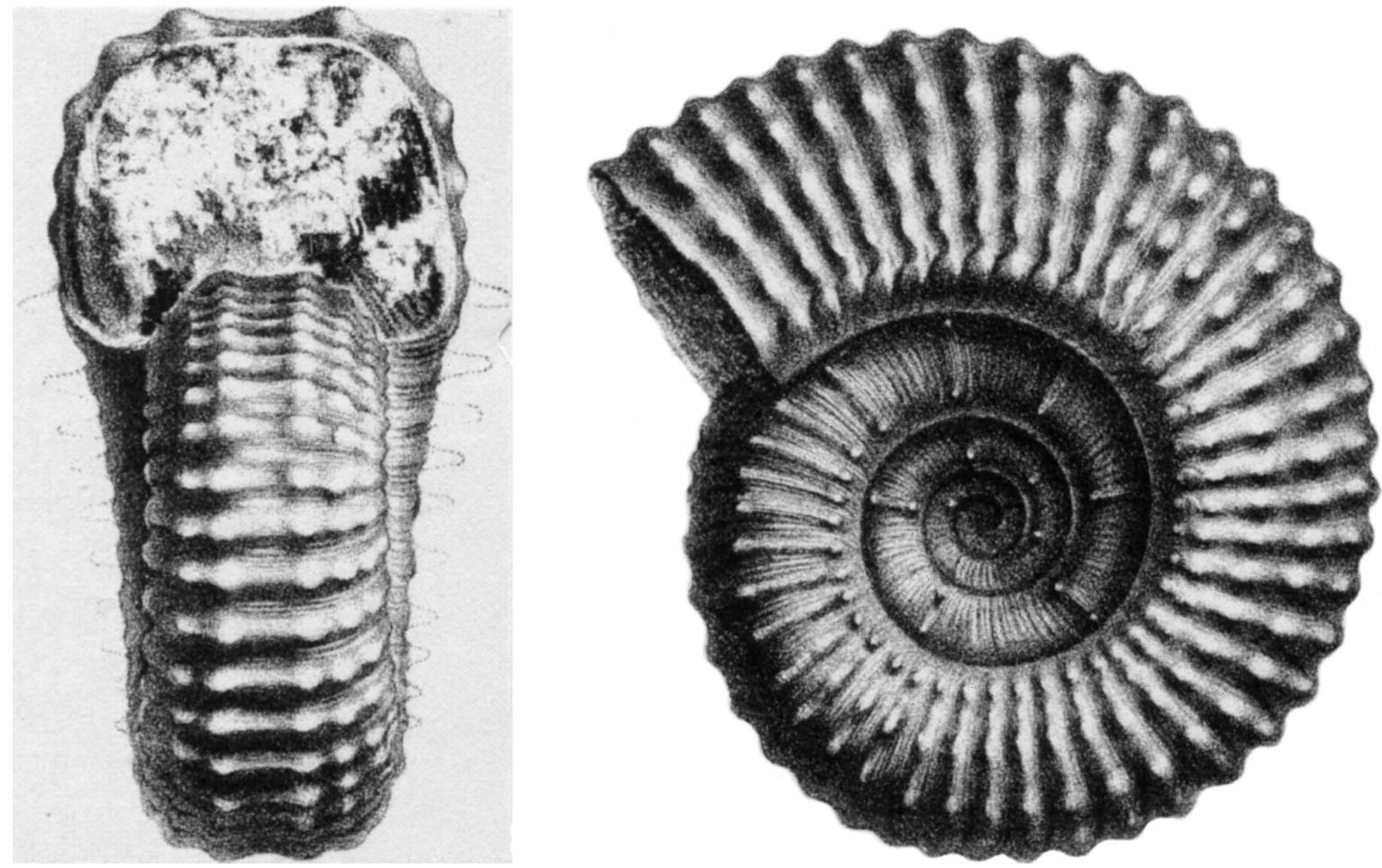

Fig. 19. Douvilleiceras solitae (d'Orbigny, 1853). Copy of d'Orbigny, 1853, pl. 4, figs 1, 2, based on a specimen 100-110 mm in diameter from the côte de Petaquero of Nouvelle Grenade, that is to say Colombia.
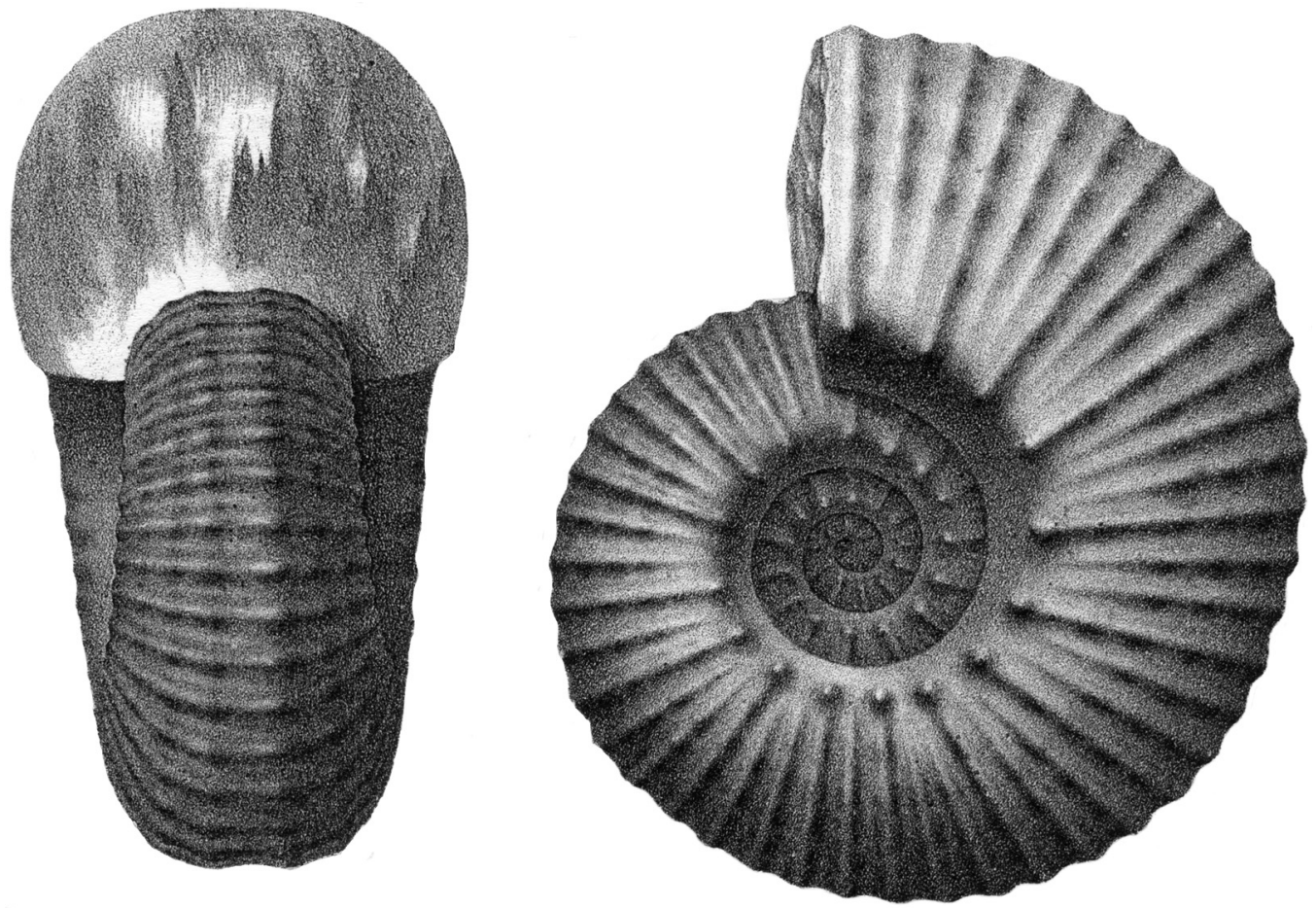

Fig. 20. Douvilleiceras invernoisi (Coquand, 1865). Copy of Ammonites mammillatus of Pictet \& Renevier 1865, pl. 2, fig. 1, a specimen said to be $160 \mathrm{~mm}$ in diameter, from Perte-du-Rhône (Ain), France, and a syntype of the species. 


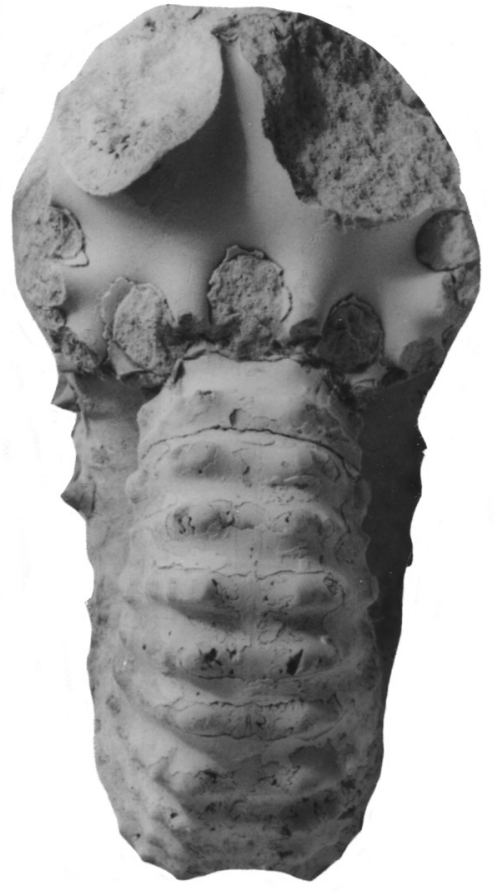

A

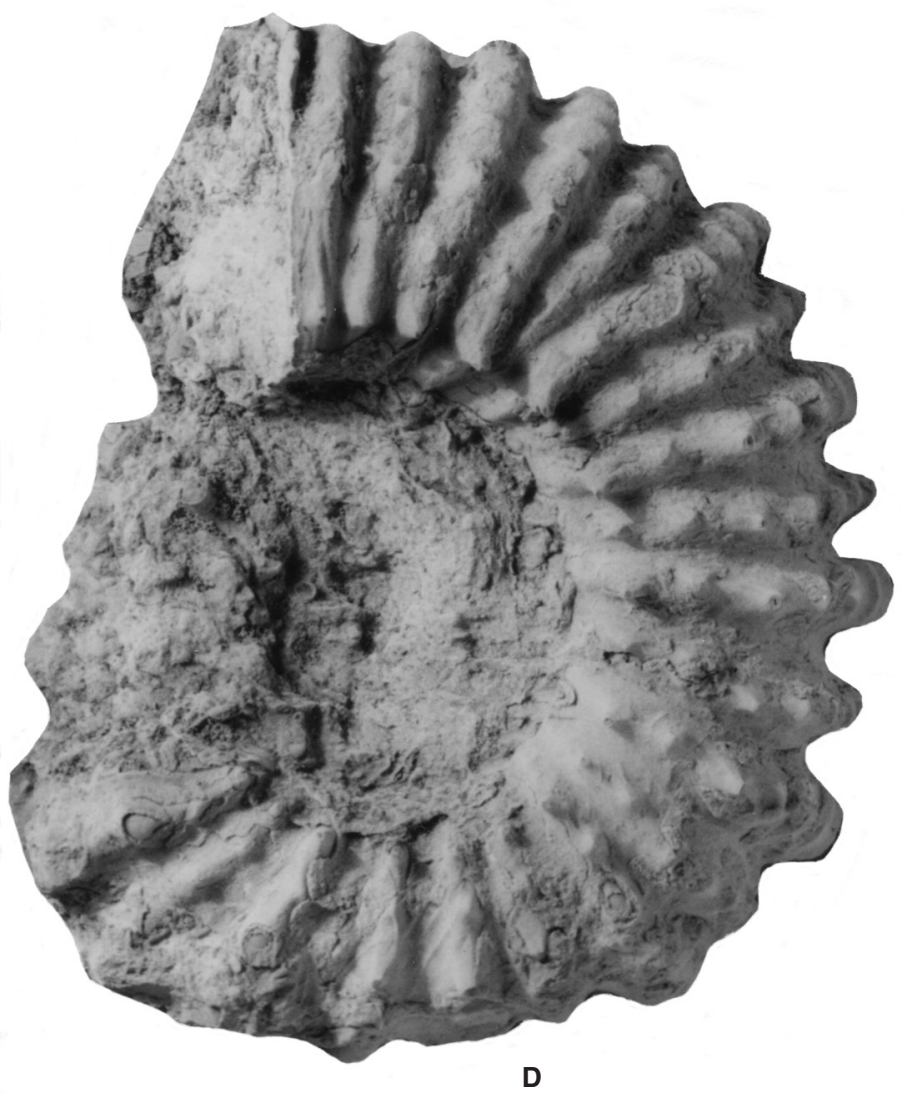

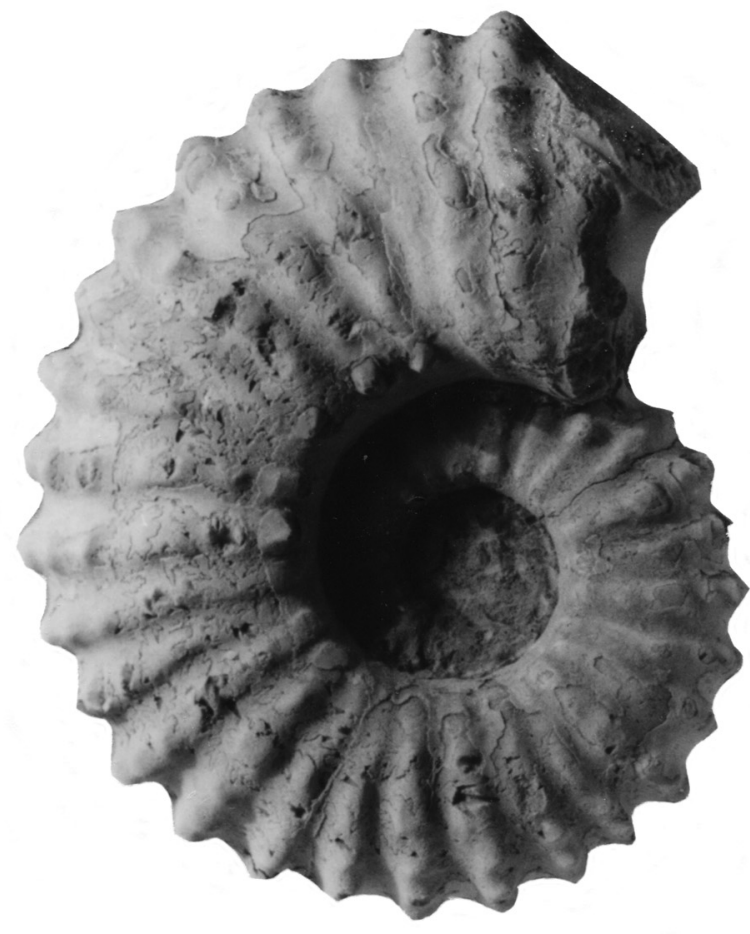

B

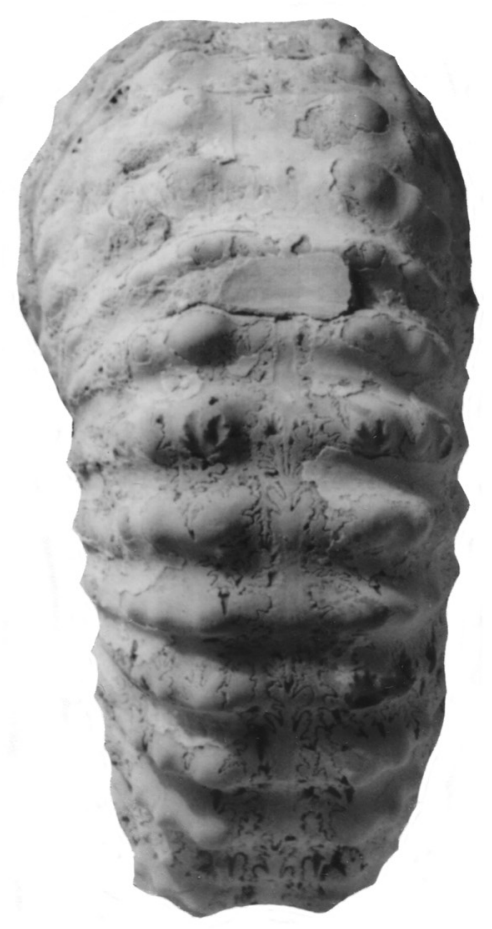

C

Fig. 21. Douvilleiceras from the Albian of Madagascar. A-C, original of Douvilleiceras mammillatum (Schlotheim) of Collignon 1963, pl. 283, fig. 1241, from the 'Albien Moyen. Zone à Lemuroceras spathi et Brancoceras besairiei' of Ambarimaninga, Madagascar. D, E, original of Douvilleiceras monile J. Sow. of Collignon 1963, pl. 287, fig. 1247, from the 'Albien Inférieur. Butte-témoin du Malandiandro (Mitsinjo-Namakia), Madagascar.' Both specimens are housed in the collections of the Université de Bourgogne, Dijon, France. All figures are $\times 1$. 


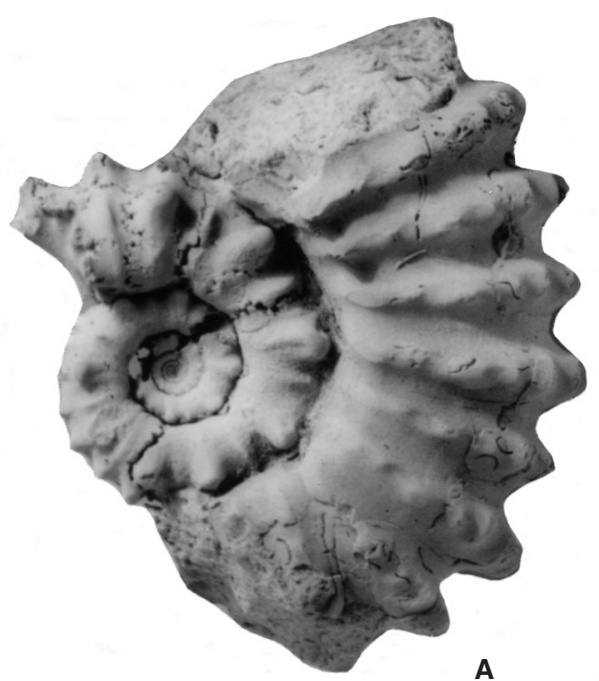

A

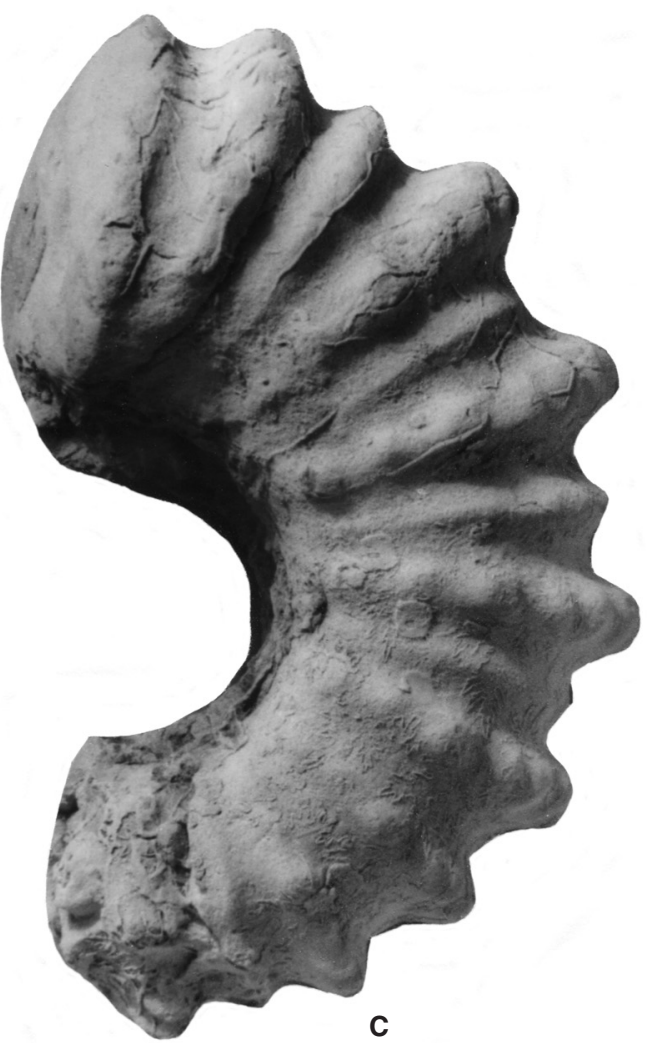

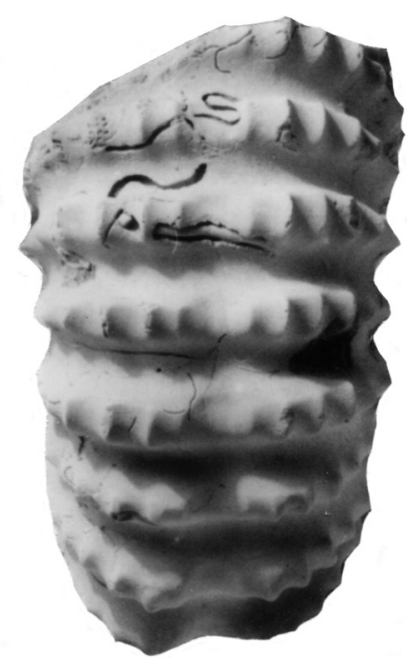

B

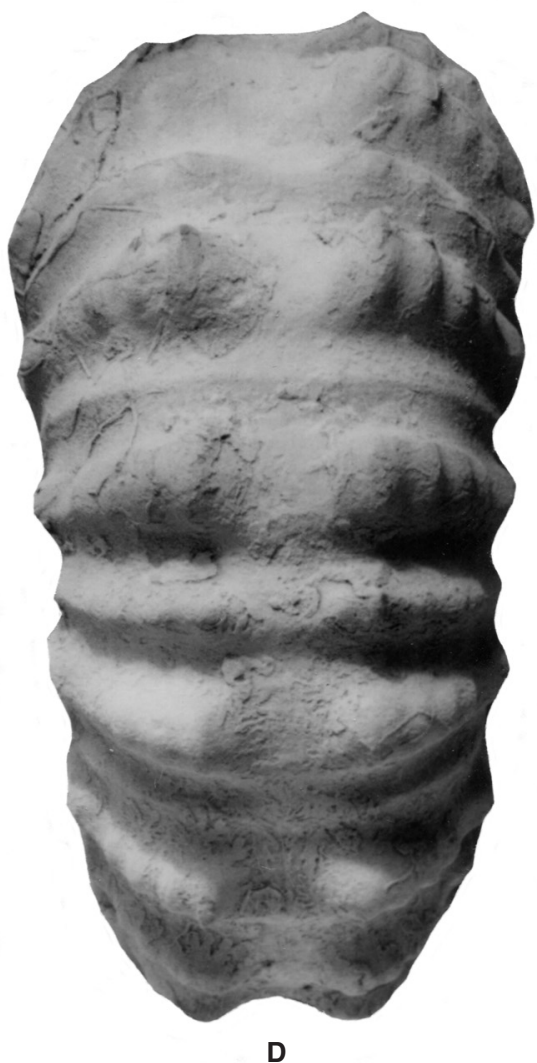

Fig. 22. A, B, Douvilleiceras mammillatum (Schlotheim, 1813). Original of Collignon 1963, pl. 283, fig. 1239, from Ambarimaninga (MitsinjoNamakia), Madagascar. C, D, Douvilleiceras inaequinodum (Quenstedt, 1849). Original of Douvilleiceras aff. baylei Spath of Collignon 1963, pl. 287, fig. 1248, from the 'Albien Inférieur. Butte-témoin du Malandiandro (Mitsinjo-Namakia), Madagascar.' Both specimens are housed in the collections of the Université de Bourgogne, Dijon, France. All figures are $\times 1$. 

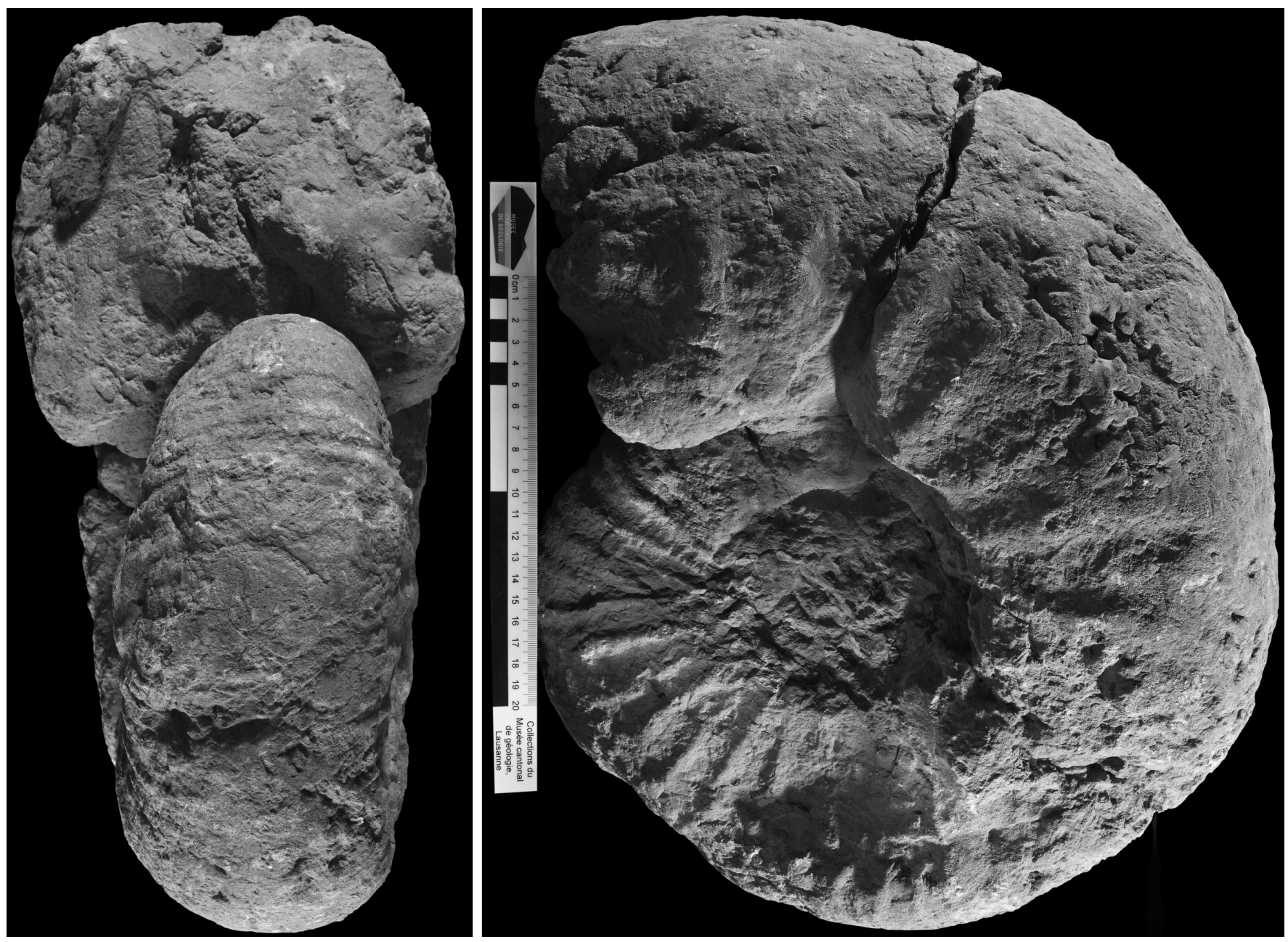

Fig. 23. Douvilleiceras sp. group of mammillatum (Schlotheim, 1813). The surviving syntype of Douvilleiceras invernoisi (Coquand, 1865), no. MGL15704 in the collections of the Musée Cantonal de Géologie de Lausanne, from the Lower Albian of Lancrans, Ain, France. Reduced $\times 0.23$; the original is $560 \mathrm{~mm}$ in diameter. 